wy

الإحتياجات الإرشادية للزراع لممارسات ترشيد إستخدام المبيدات الكيماوية فى مكافحة آفات الطماطم ببعض قرى محافظة المنيا

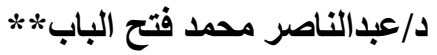

د/اد هم محمد زكى محمود الاد

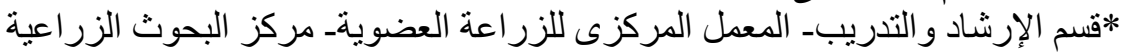

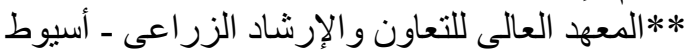

المستخلص

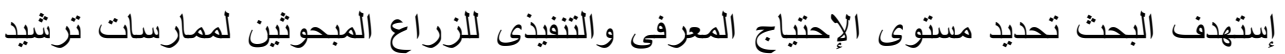

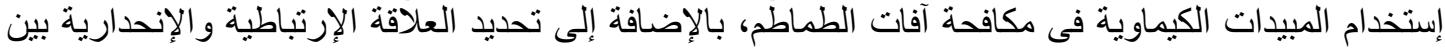

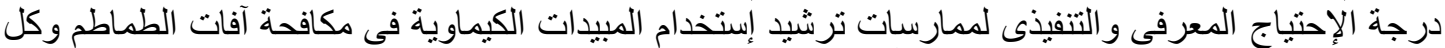

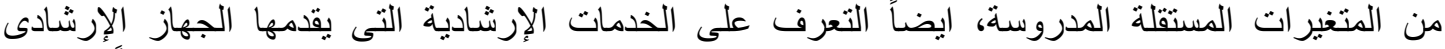

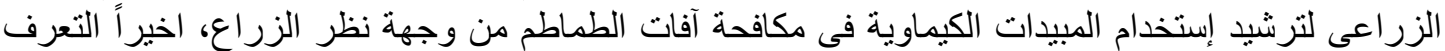

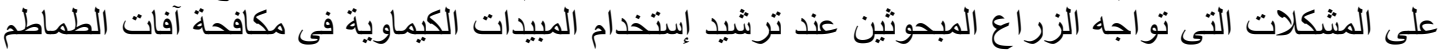

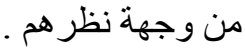

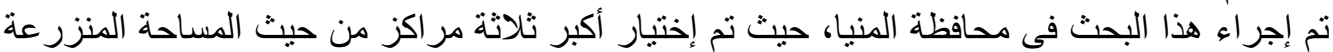

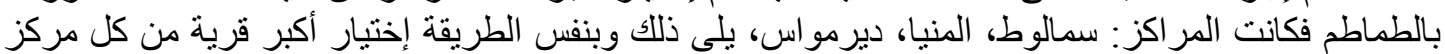

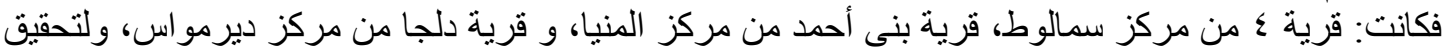

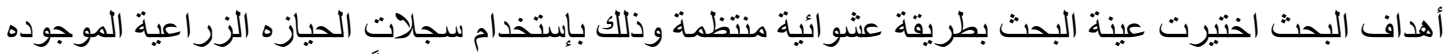

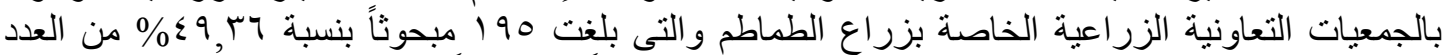

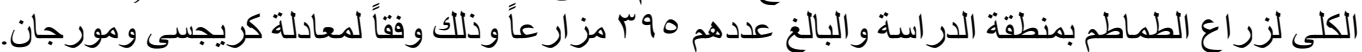

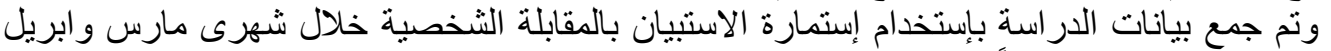

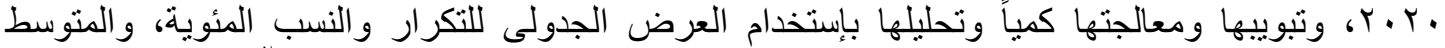

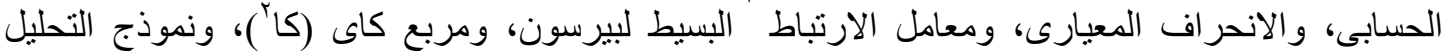

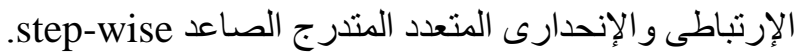

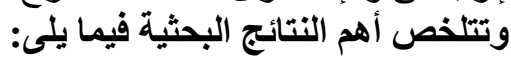

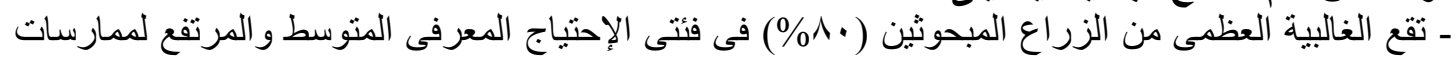

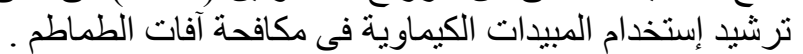

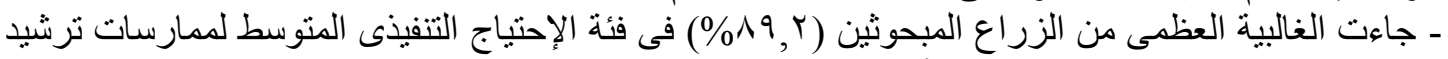

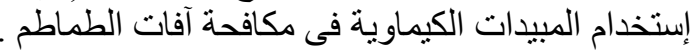

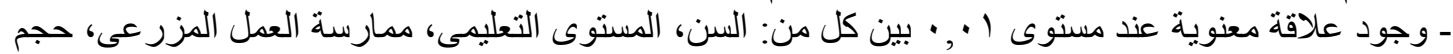

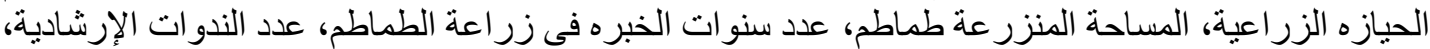

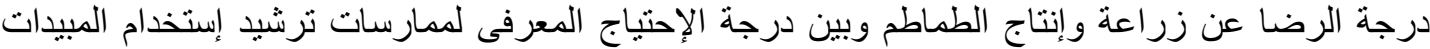

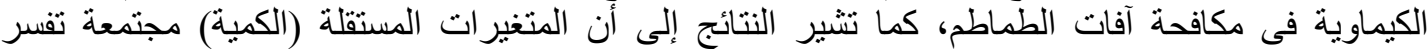

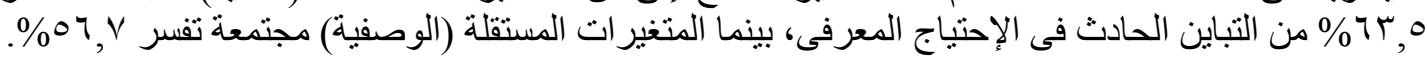

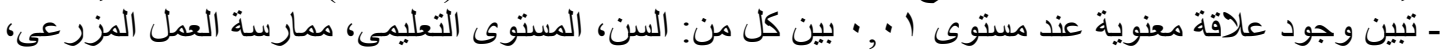

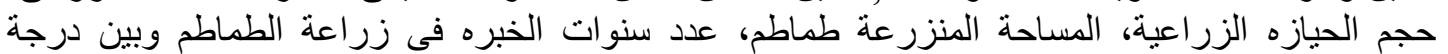

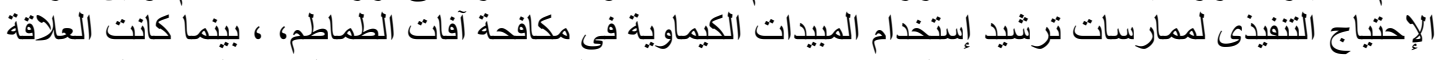

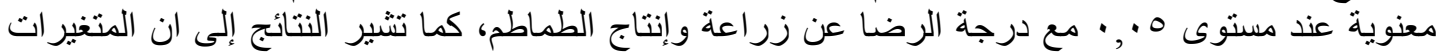

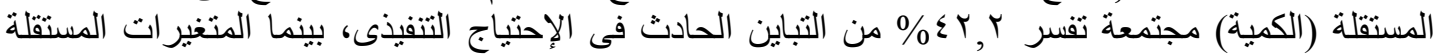

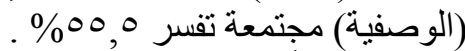

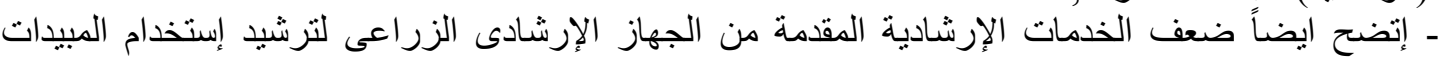

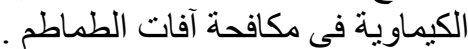

ـ تراوحت أهم المشكلات التى تواجه الزراع الفئ المبحوثين عند ترشيد إستخدام المبيدات الكيماوية فى مكافحة

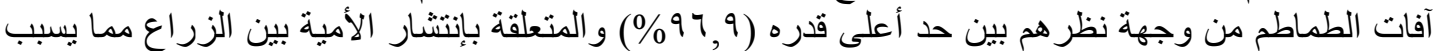

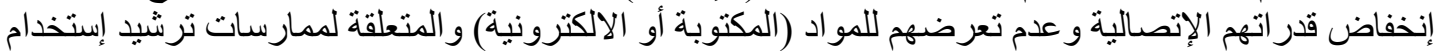

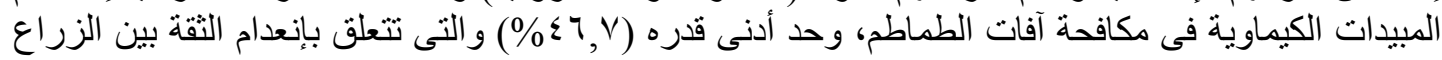

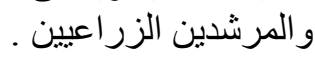

Fayoum J. Agric. Res. \& Dev., Vol. 34, No.2 July, 2020 


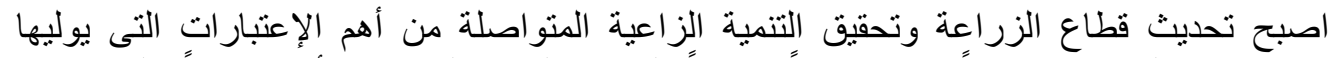

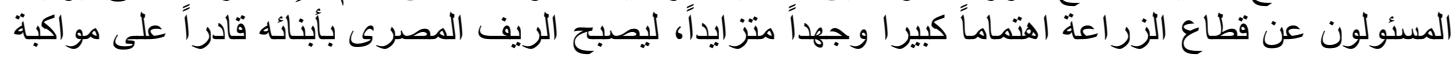

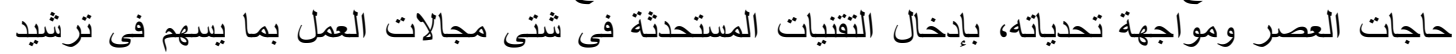

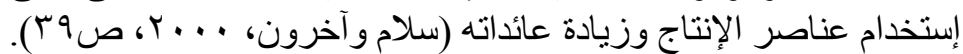

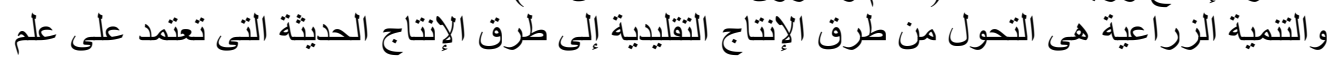

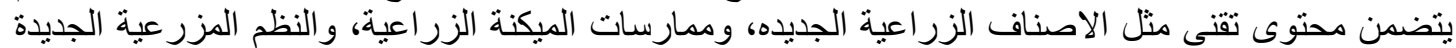

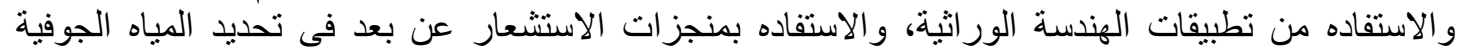

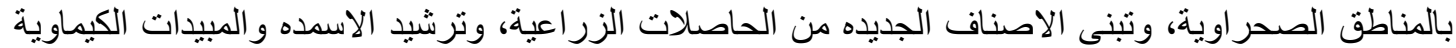

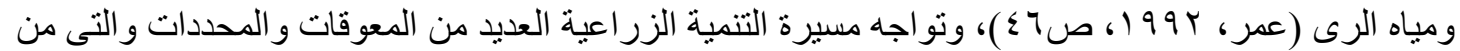

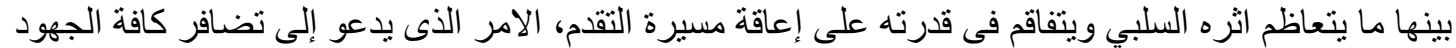

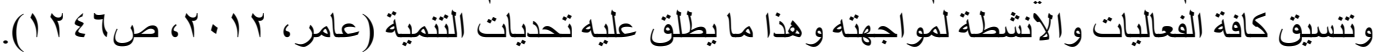

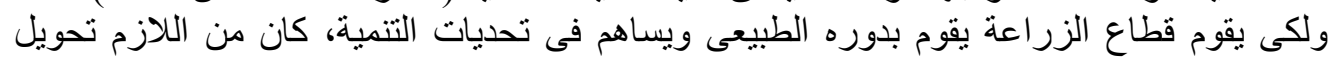

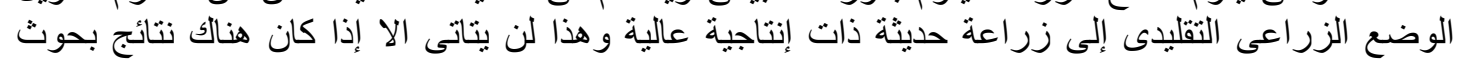

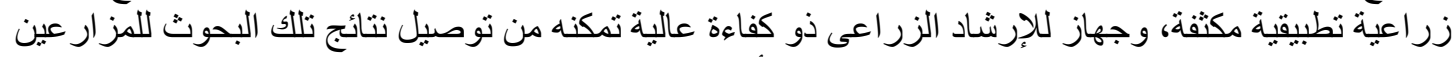

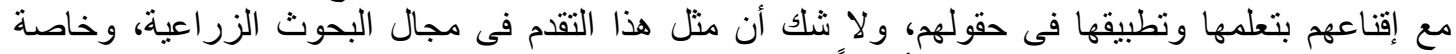

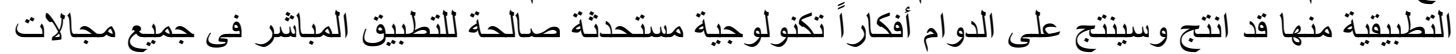

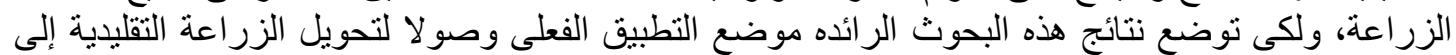

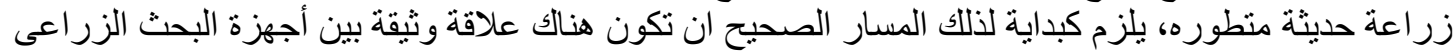

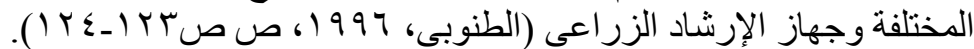

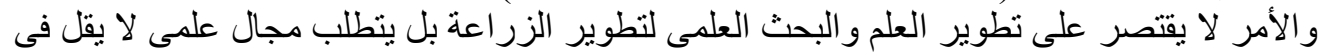

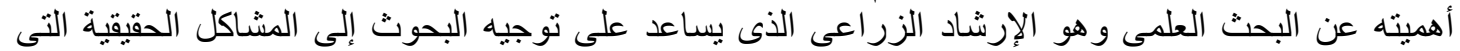

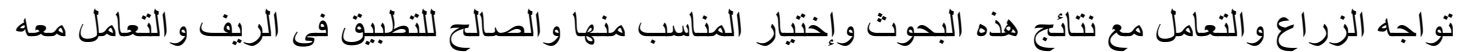

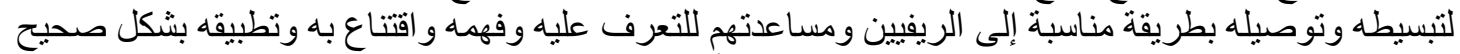

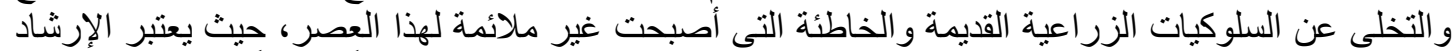

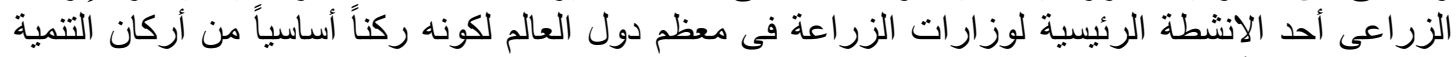

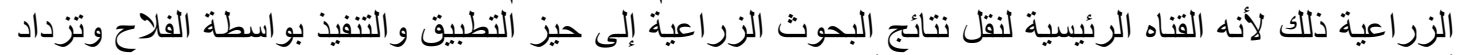

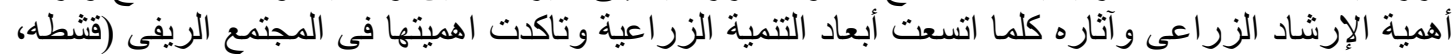

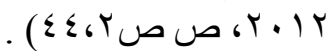

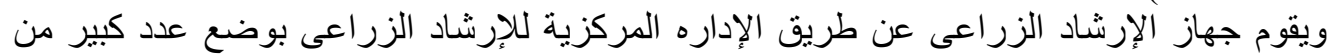

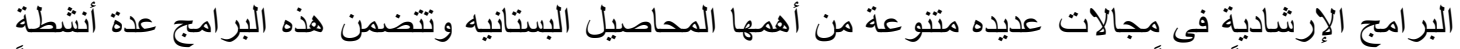

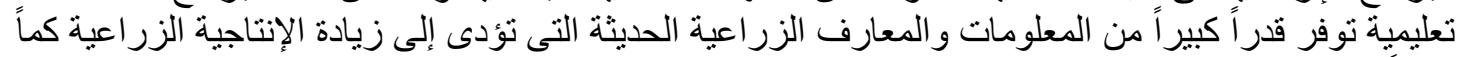

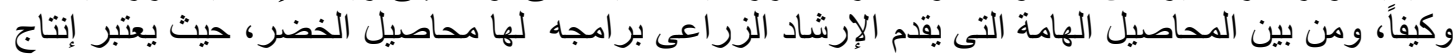

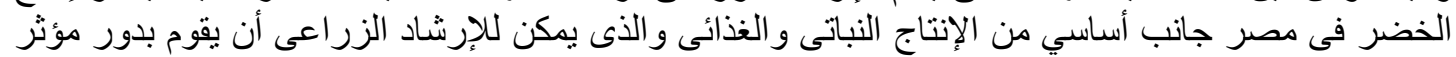

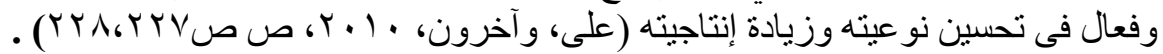

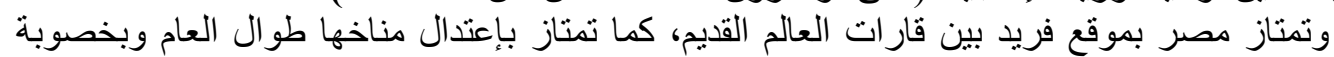

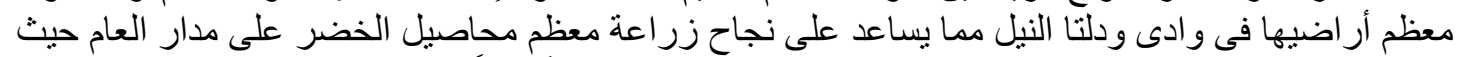

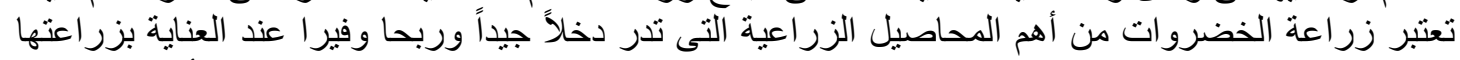

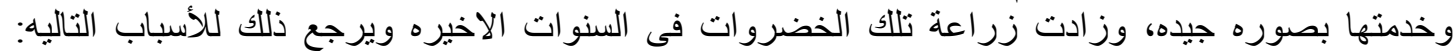

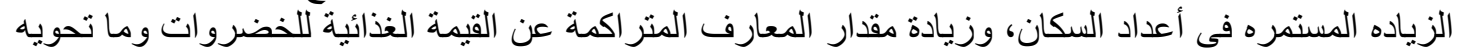

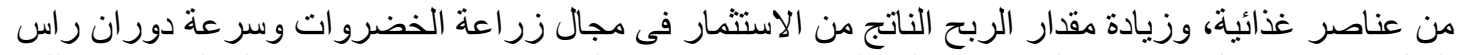

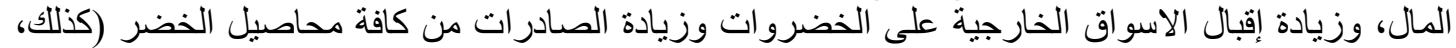

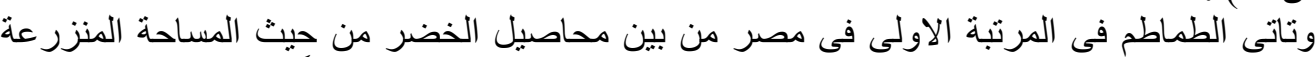

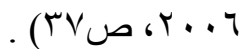

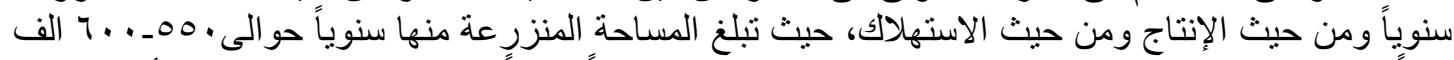

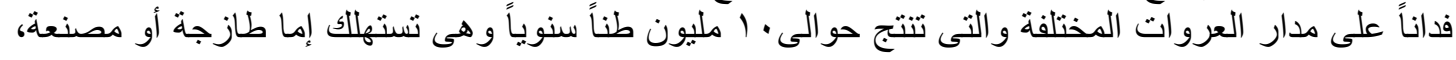

Fayoum J. Agric. Res. \& Dev., Vol. 34, No.2 July, 2020 
$\boldsymbol{\mu}$

وبإستخدام التوصيات العلمية الحديثة بداية من إختيار الصنف المنسب مع توفير افضل الظروف والئاف والمعاملات

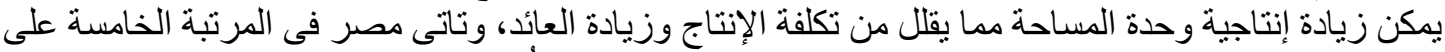

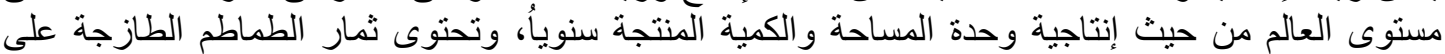

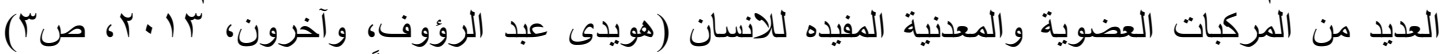

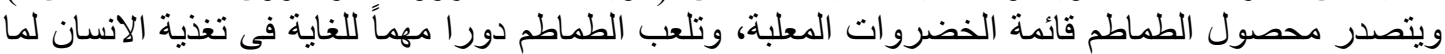

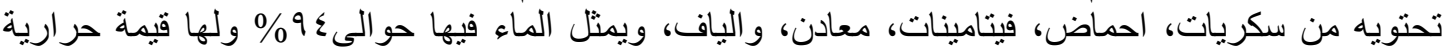

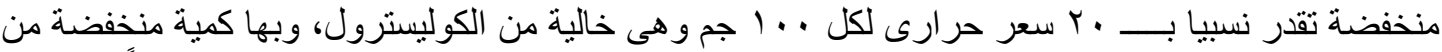

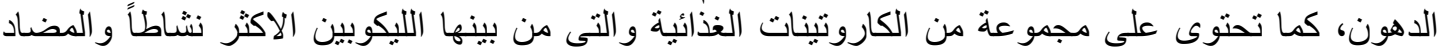

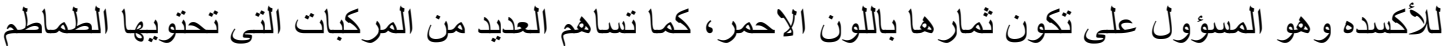

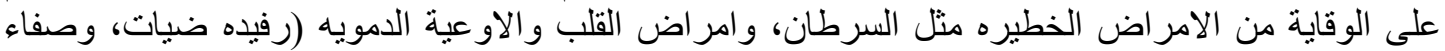

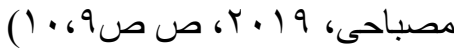

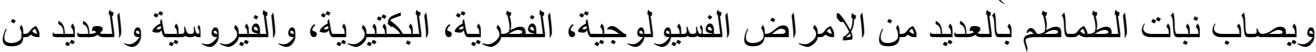

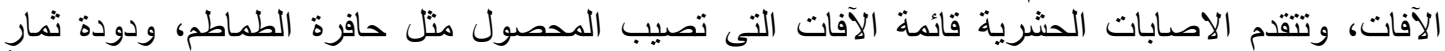

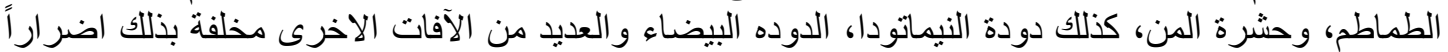

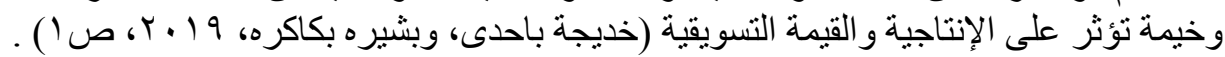

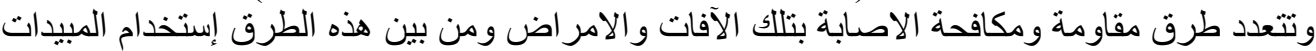

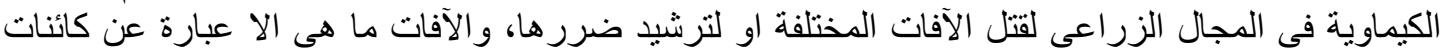

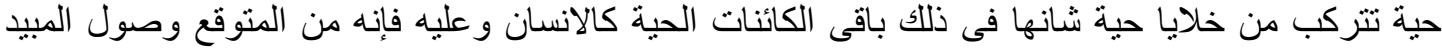

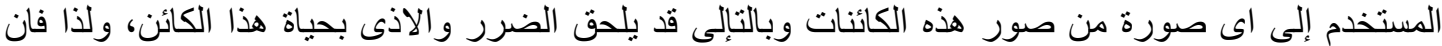

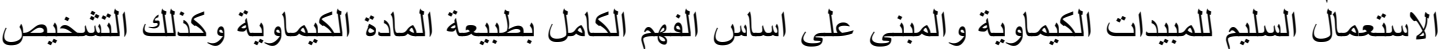

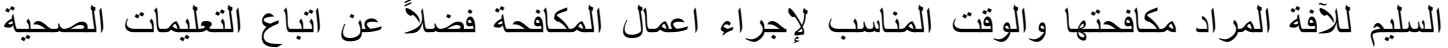

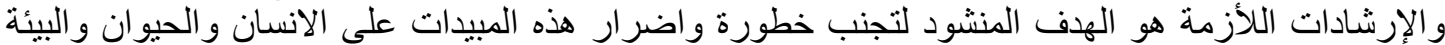

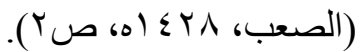

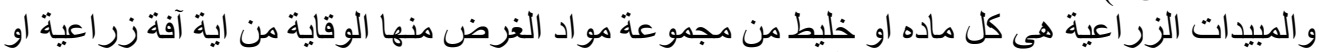

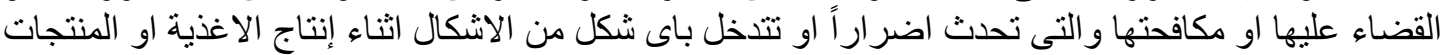

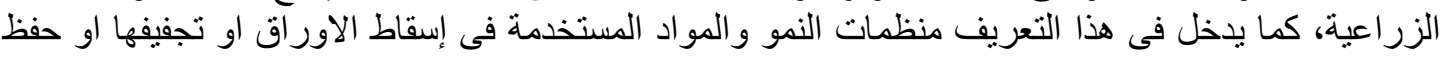

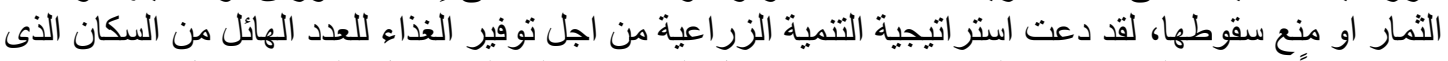

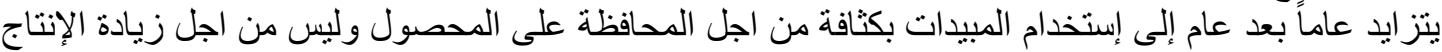

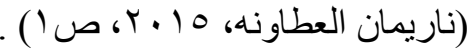

وقد اكد تقرير حديث مشترك بين منظمة الأغذية والزراعة (الفاو) وبرنامج الأمم المتحده للبيئة

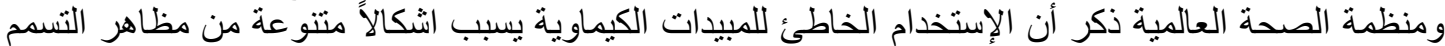

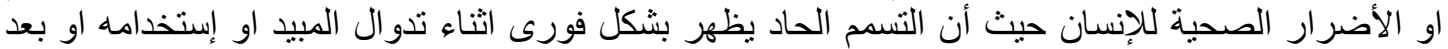

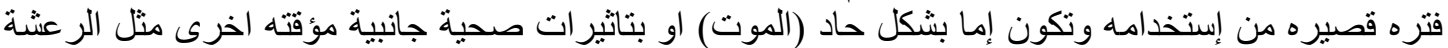

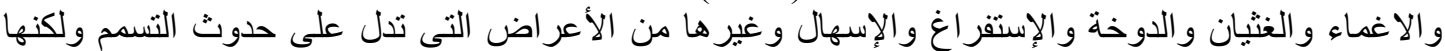

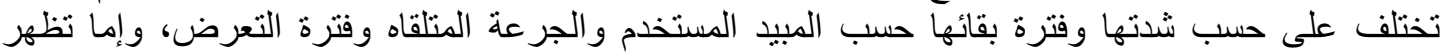

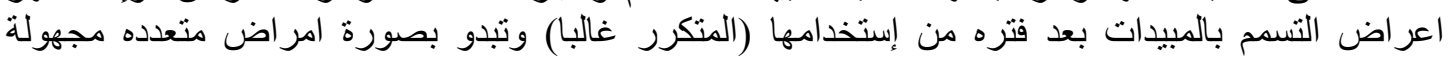

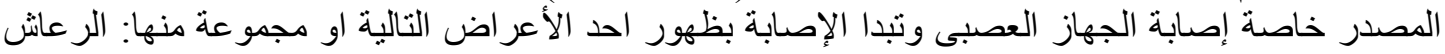

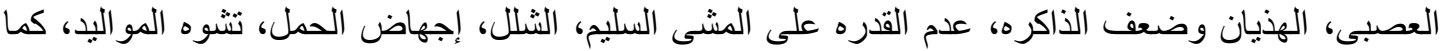

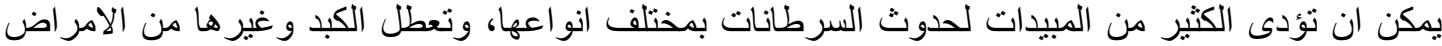

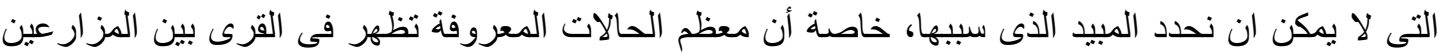

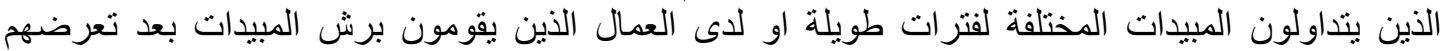

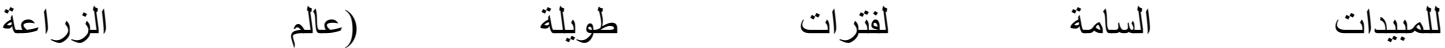

. (http://www.agricultureegypt.com/NewsDetails.aspx?

و لا تتمثل خطورة المبيد فقط فى تتاوله عن طريق الفم او اكل الخضر و الفاكهة الطازجة ولكن يمكن ان

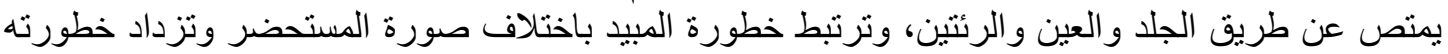

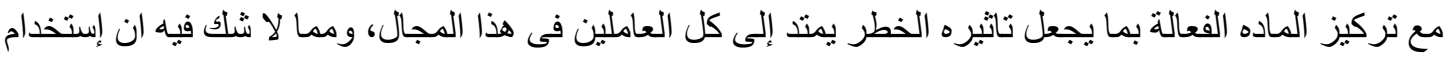

Fayoum J. Agric. Res. \& Dev., Vol. 34, No.2 July, 2020 
rq

المبيد بجر عة اكبر من الموصى بها او المغشوشة او المحظورة يؤدى إلى زيادة المتبقى منه فى المحصول او

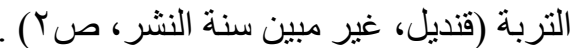

ولعل من ابرز اهم الآثار السلبية الناجمة عن الإسراف فئنى فئ إستخدام المبيدات عن معدلاتها الطبيعية

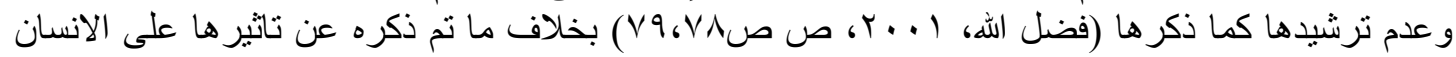

وصحته:

ا - يؤدى رش المحاصيل الزر اعية بالمبيدات الكيماوية إلى القضاء على الكائنات الدقيقة الموجوده بالتربة

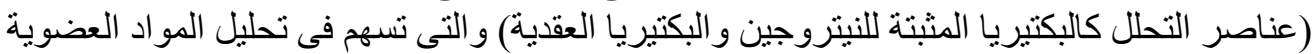

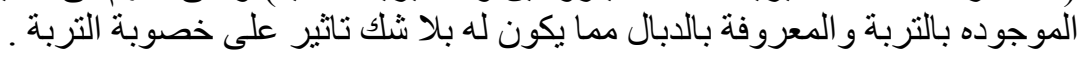

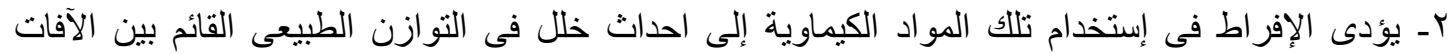

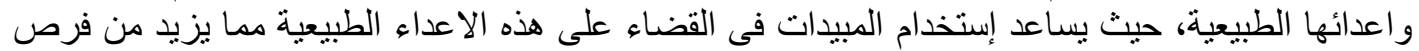

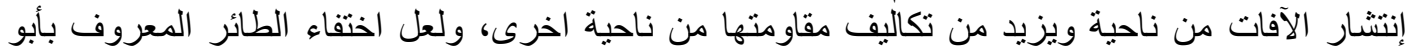

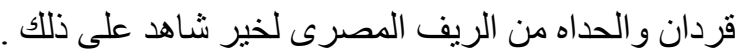

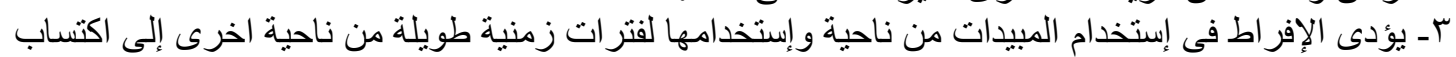

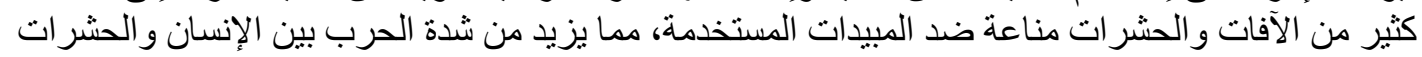

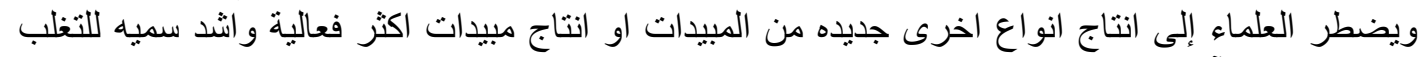

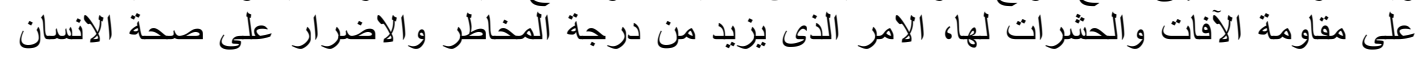

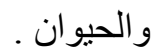

عـ ان كثير من المبيدات الحثرية يبقى آثنارها لمدة طويلة فى التربة الزراعية مما يعنى إستمرار تاثيرها

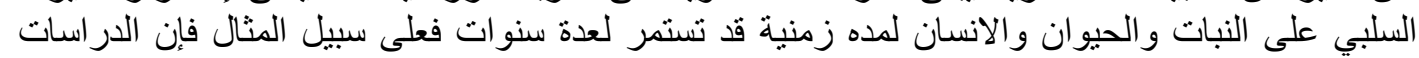

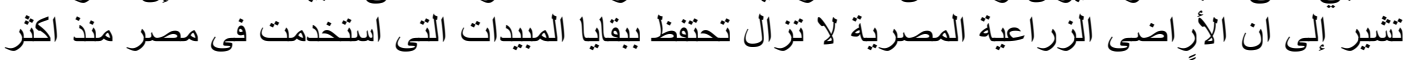

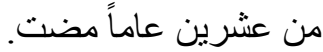

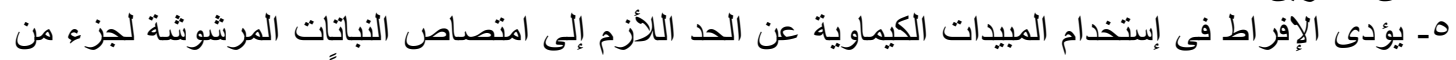

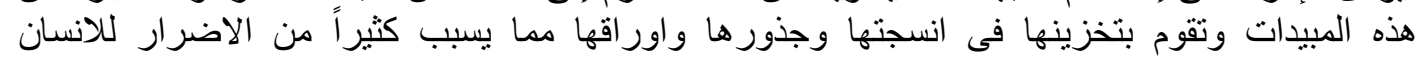

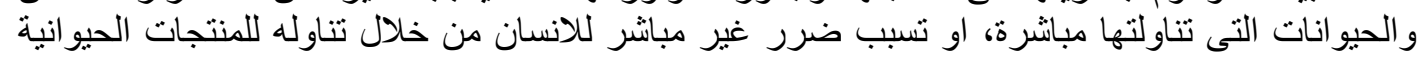

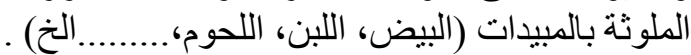

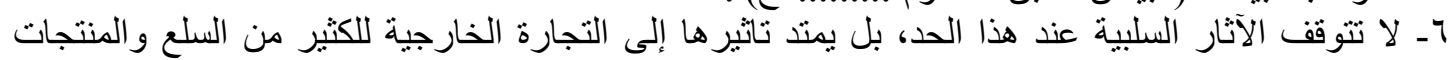

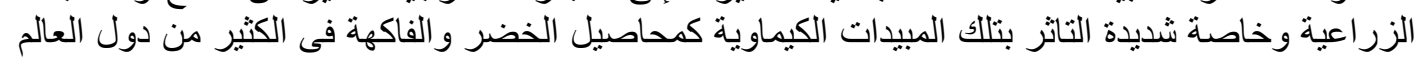
(وخاصة النامية منها) وذللك عندما تتجاوز مستوى منبقيات المبيدات والحد المسموح به لدى الدى الدول المستورده.

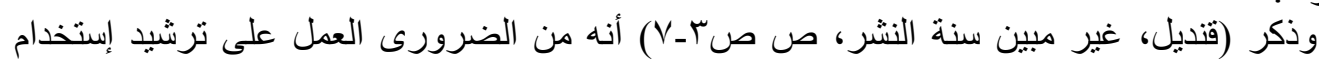
المبيدات الكيماوية بإتباع بعض الوسائل والعمليات المناسبة بهدف المحافظة على اعداد هذه الآفات عند

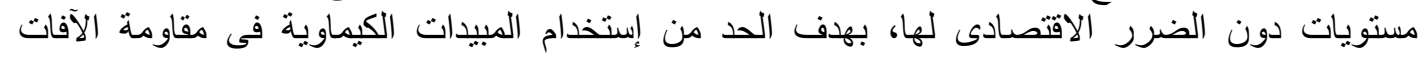

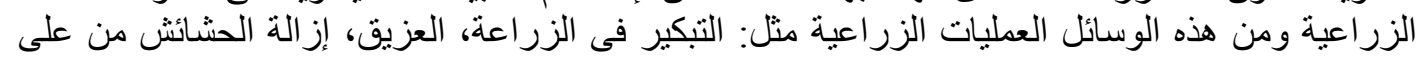

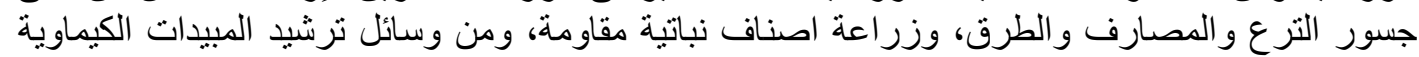

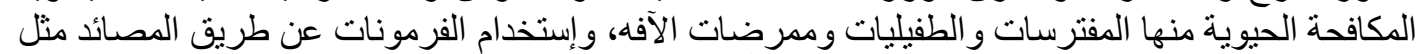

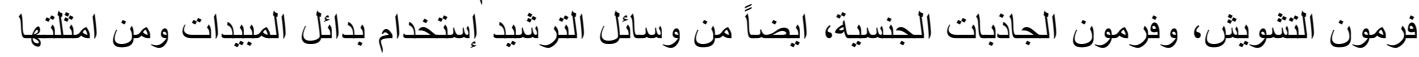

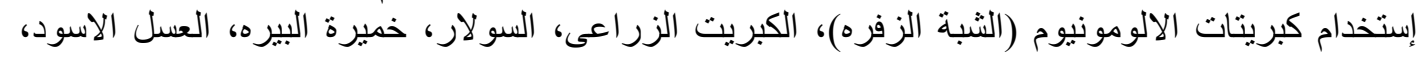

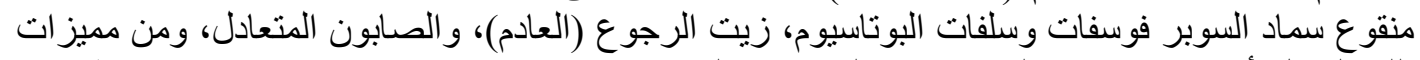

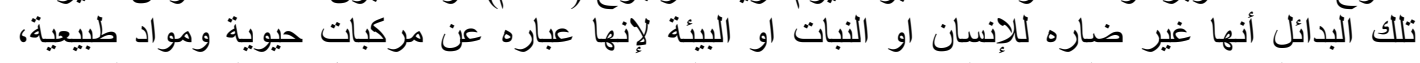

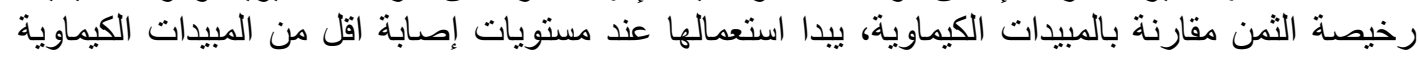

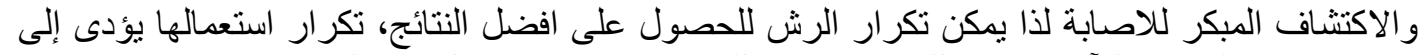

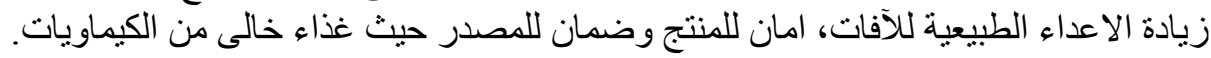

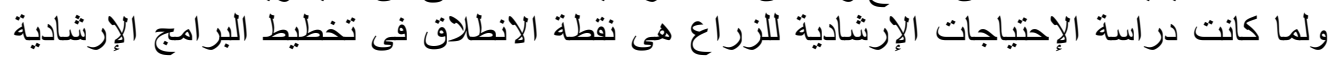

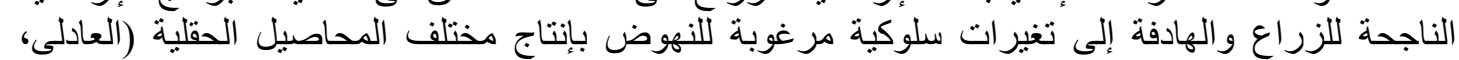

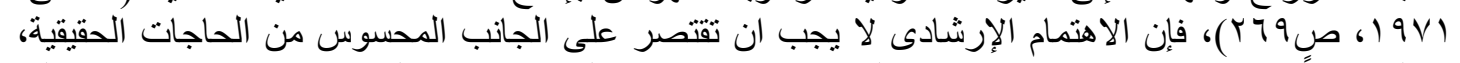

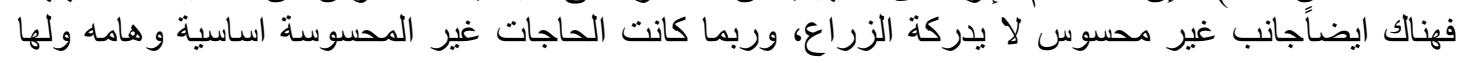

Fayoum J. Agric. Res. \& Dev., Vol. 34, No.2 July, 2020 
$\varepsilon$.

فاعليتها الكبرى فى حياتهم (Fred, 1966,p56)، لذا يجب اثارة إنتباه الزراع نحو الحاجات غير المحسوسة

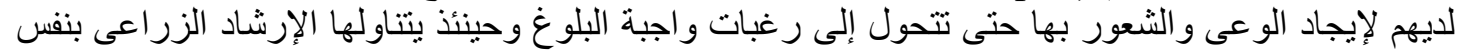

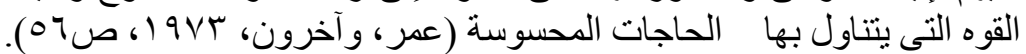

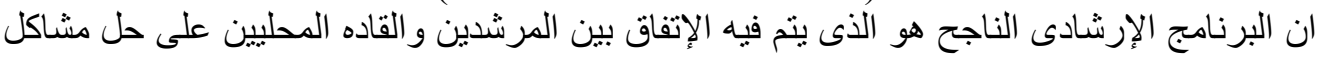

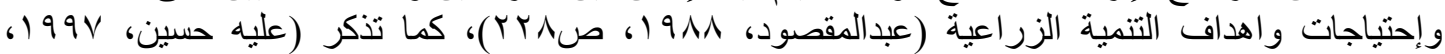

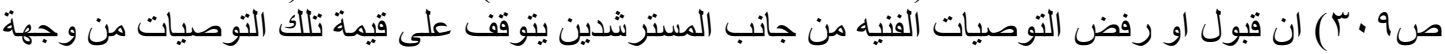

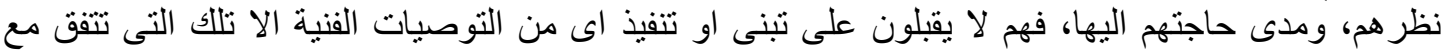

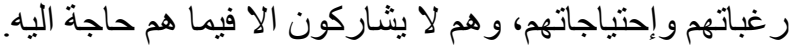

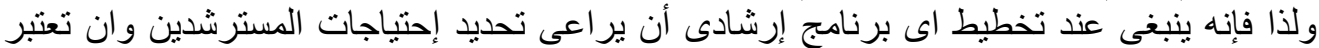

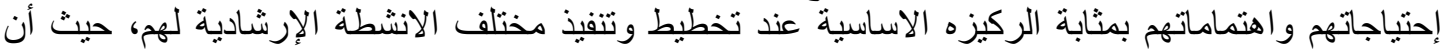

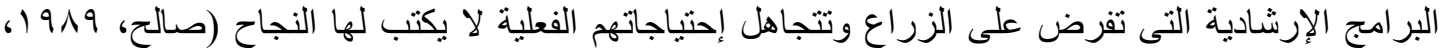

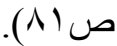

ومن الجدير بالذكر أن هناك العديد من الطرق للتعرف على الإحتياجات الإرشادية للزراع الحماع ومنها:

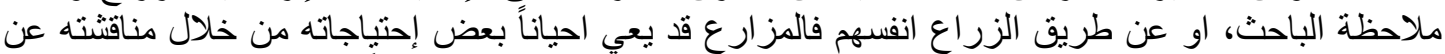

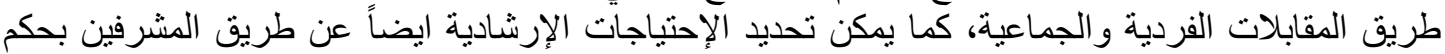

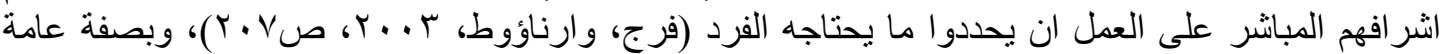

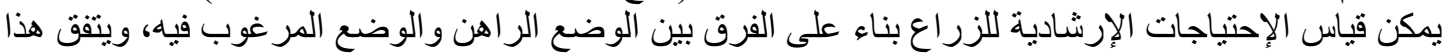

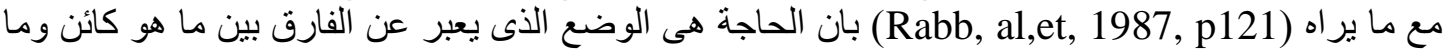

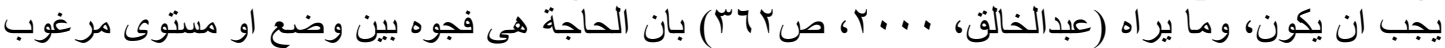

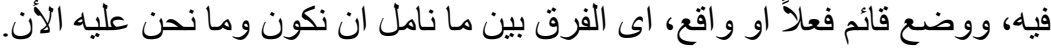

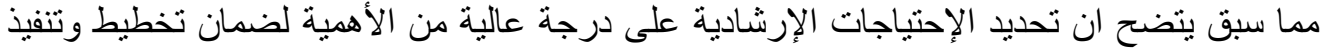

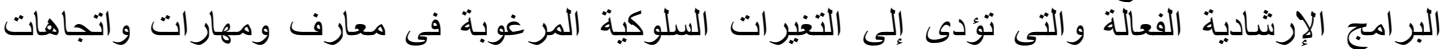

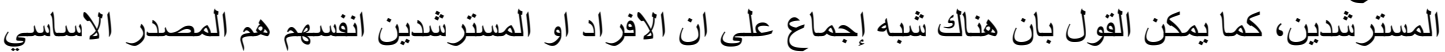

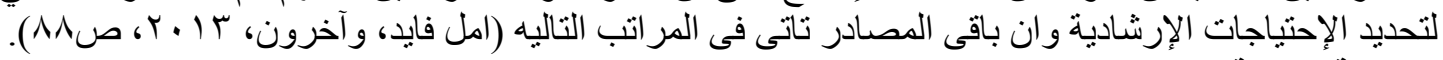

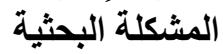

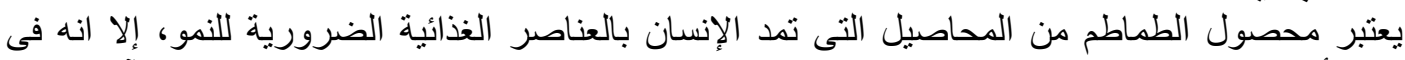

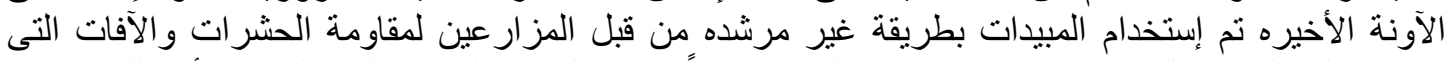

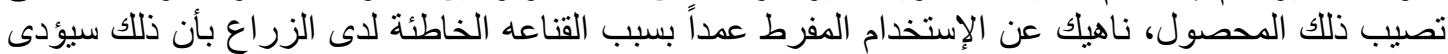

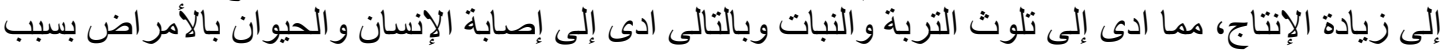

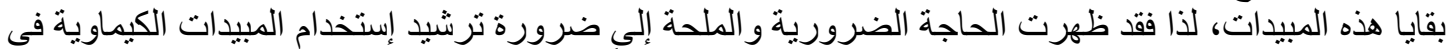

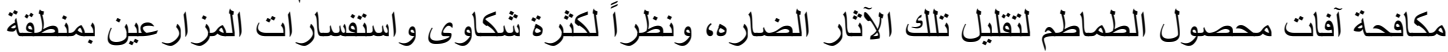

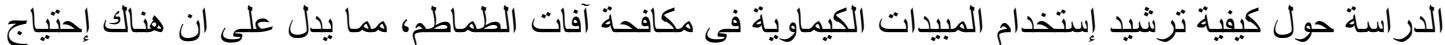

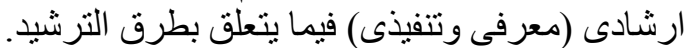

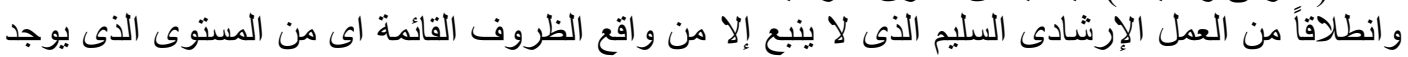

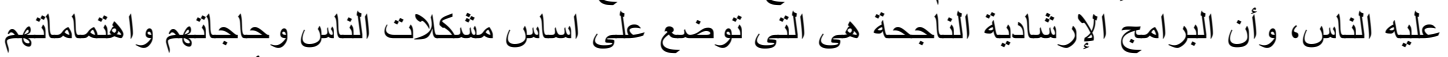

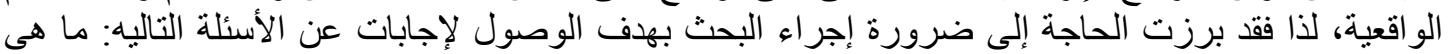

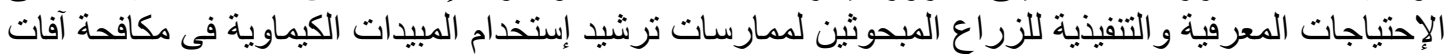

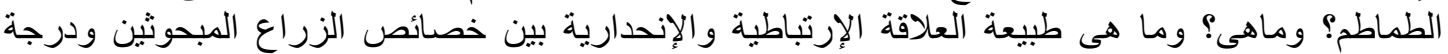

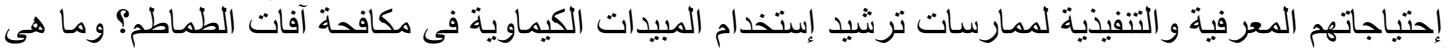

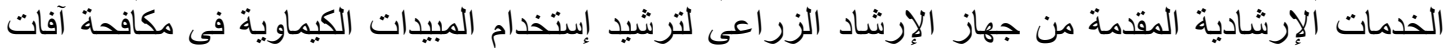

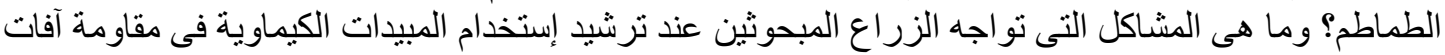

يستهدف هذا البحث بصفة أساسية در اسة الإحتياجات الإرشادية للزر اع المتاع المتلقة بترشيد إستخدام المبيدات

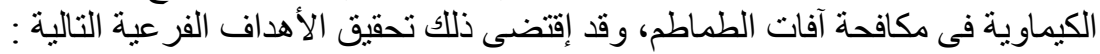

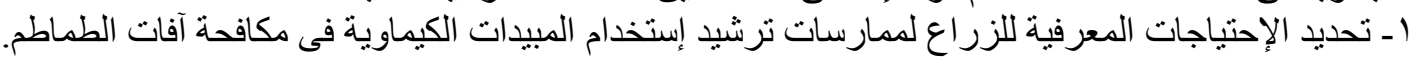

Fayoum J. Agric. Res. \& Dev., Vol. 34, No.2 July, 2020 
\&

r ـ تحديد الإحتياجات التنفيذية للزر اع لممارسات ترشيد إستخدام المبيدات الكيماوية في مكافحة آفات الطماطم.

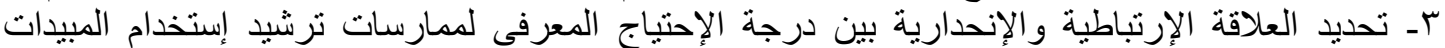

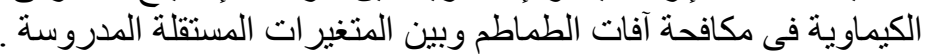

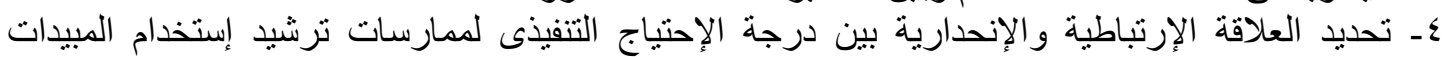

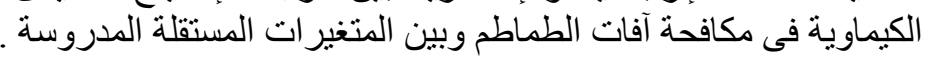

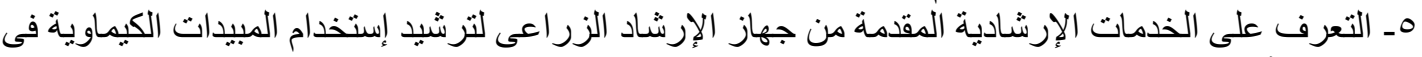

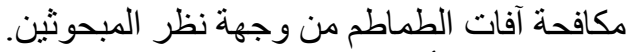

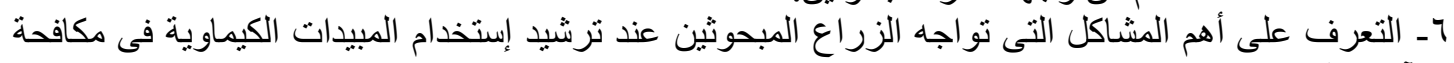

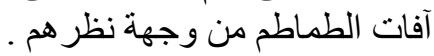
الأهمية التطبيقية للبحث الطئ

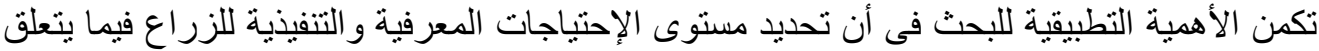

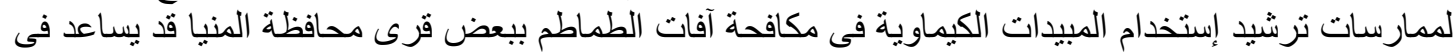

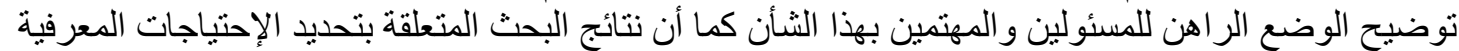

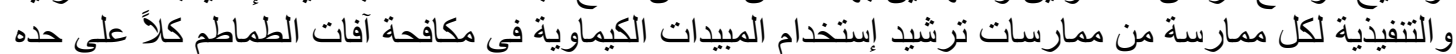

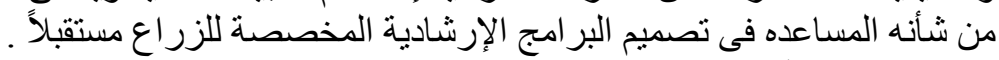

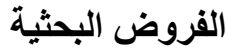

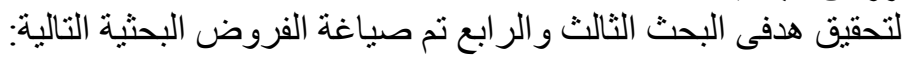

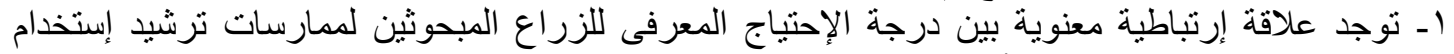

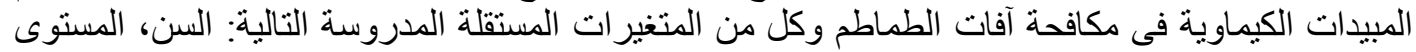

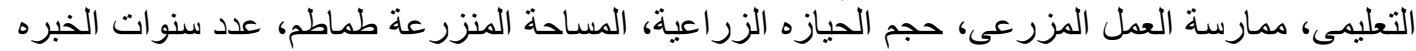

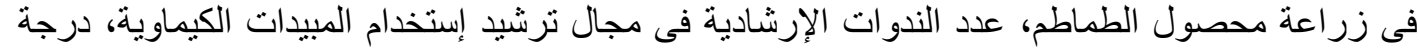

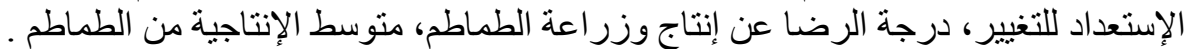

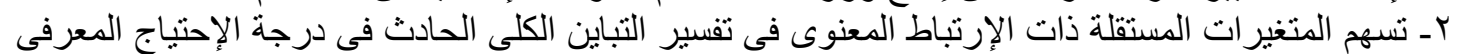

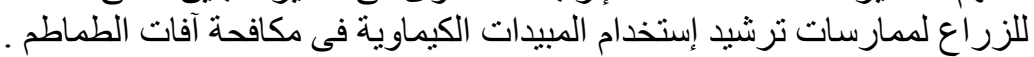

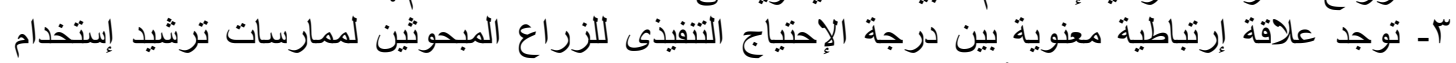

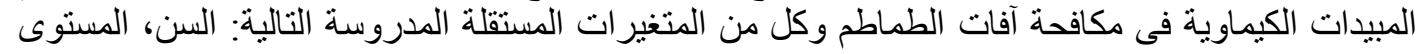

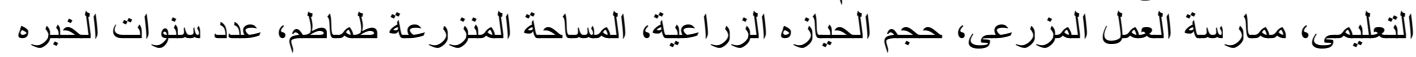

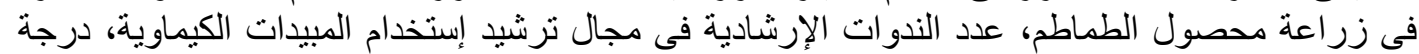

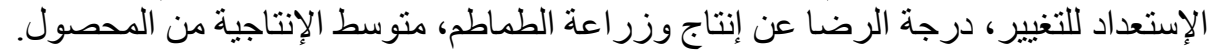

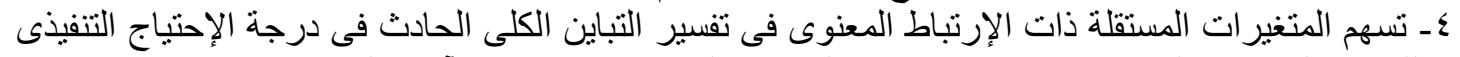

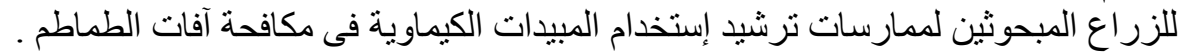

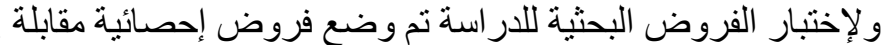

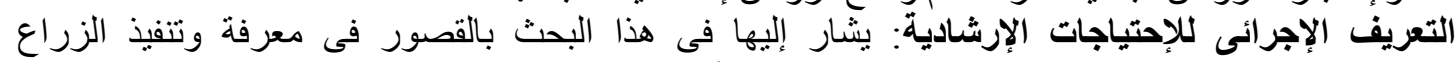

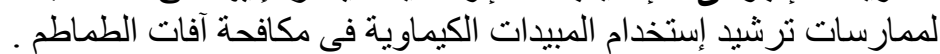

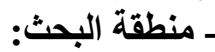

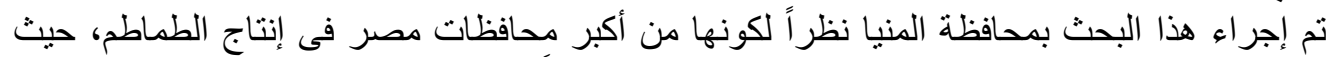

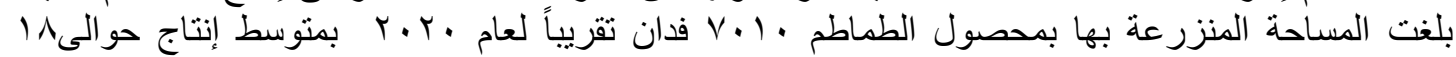

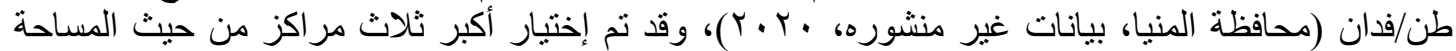

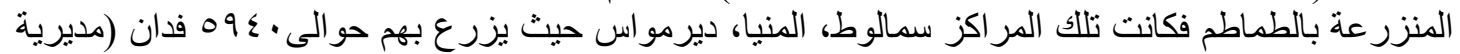

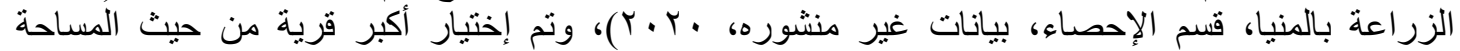

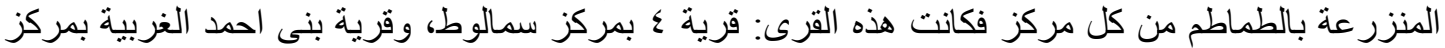

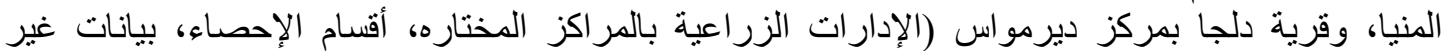

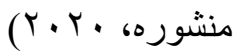

Fayoum J. Agric. Res. \& Dev., Vol. 34, No.2 July, 2020 


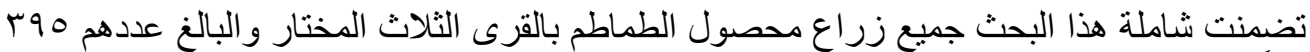

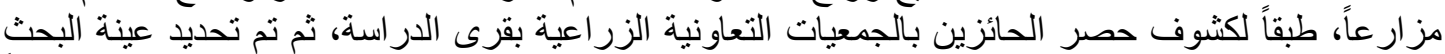

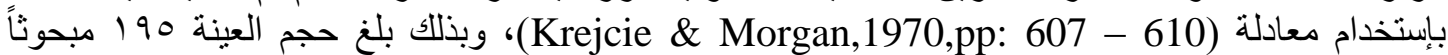

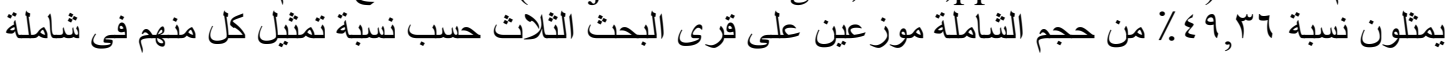

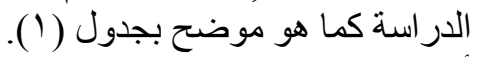
أسلوب تجميع البيانات وتحليلها: تم جمع بيانات هذا البحث بالمقابلة الثخصية لأفراد عينة البحث من زراع البحات الطماطم بو اسطة إستماره

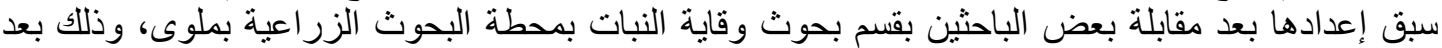

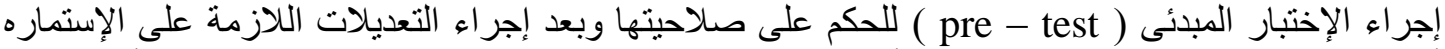

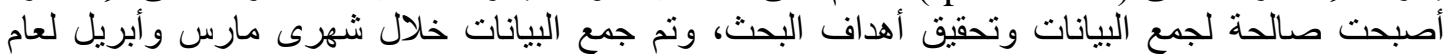

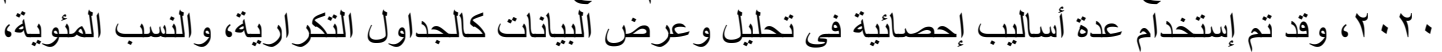

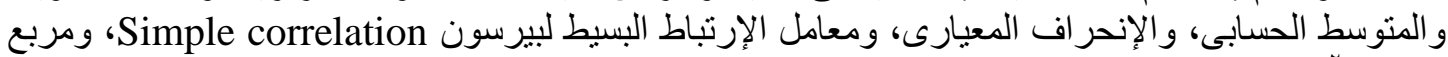

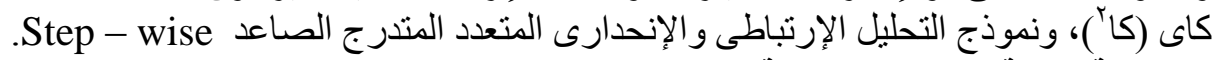

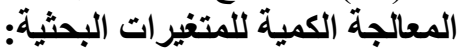

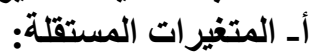

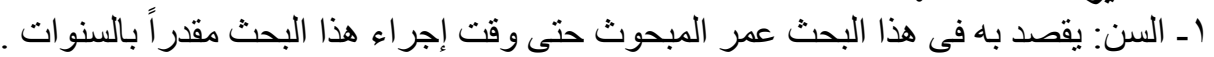

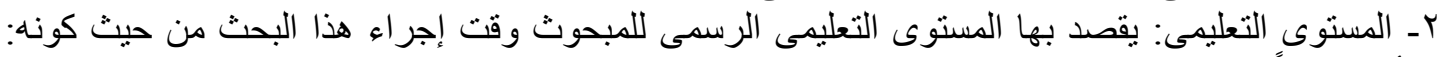

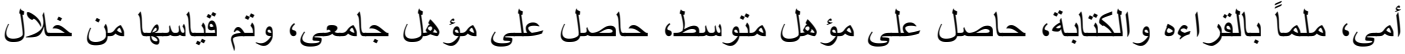

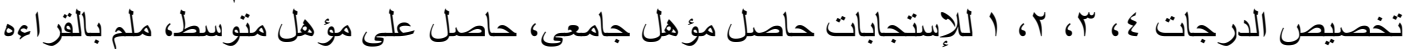

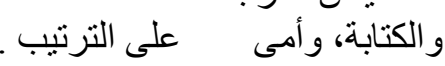

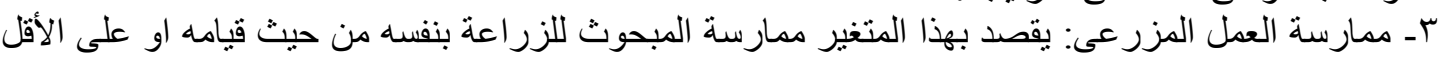

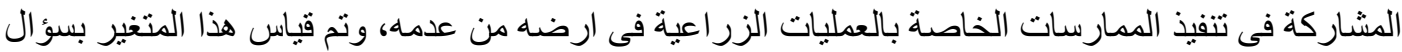

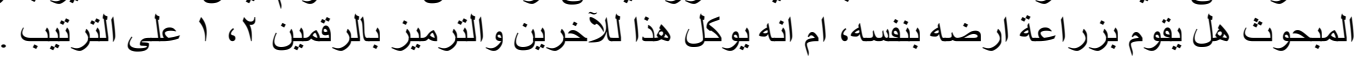

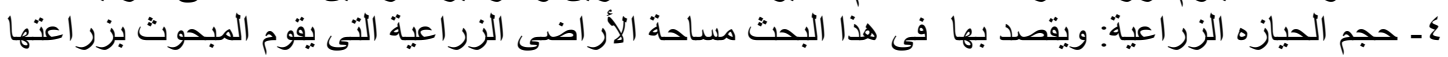

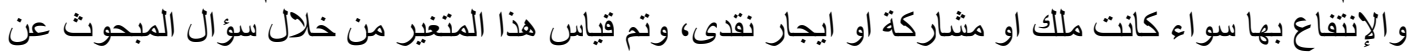

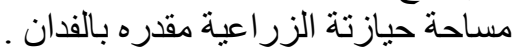

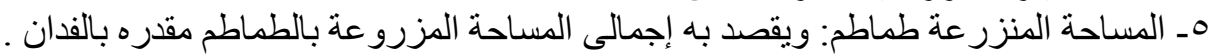

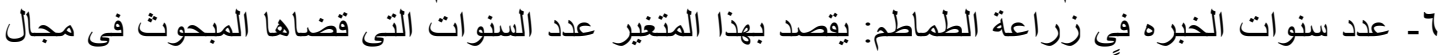

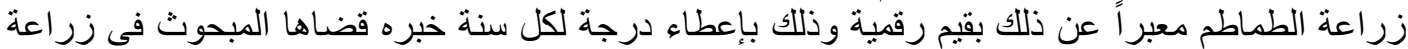
الطماطح.

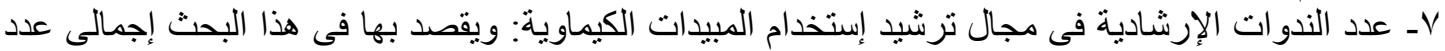

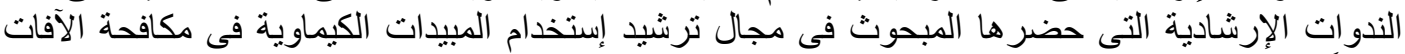
معبر أ عنها بقيم رقمية.

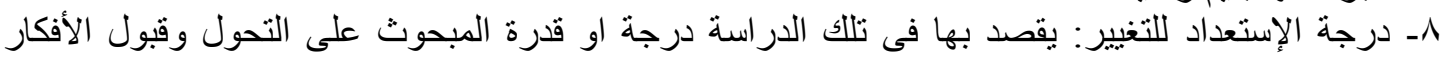

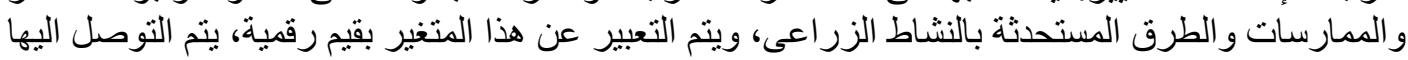

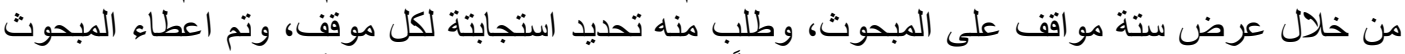

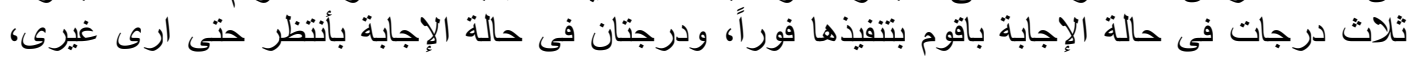

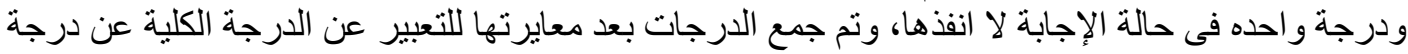

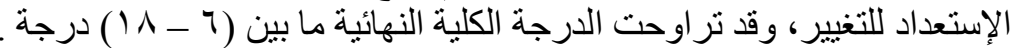

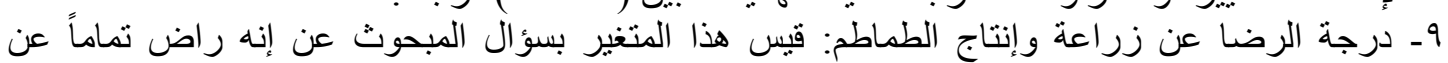

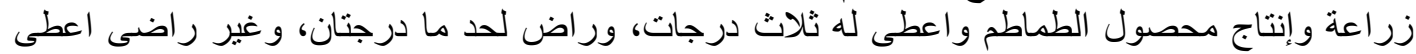

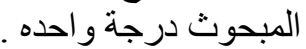
• اــ منوسط الإنتاجية من الطماطم: تم قياس هذا المتغير بسؤ ال المبحوث عن إنتاجة من محصول الطماطم ونم

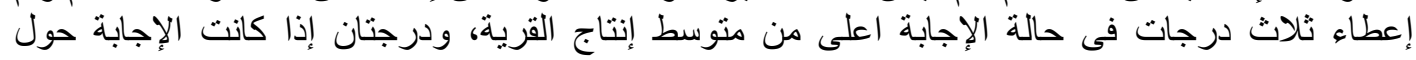
المنوسط، ودرجة و احده إذا كانت الإجابة اقل من منوسط اعلى إنتاج القرية.

Fayoum J. Agric. Res. \& Dev., Vol. 34, No.2 July, 2020 
بـ تحلد الإحتياج المعرفى والتنفيذى لممارسات ترشيد إستخدام المبيدات الكيماوية فى مكافحة آفات الطماطم

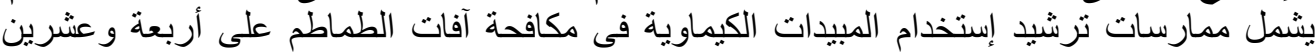

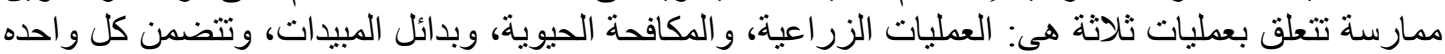

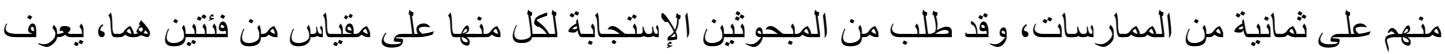

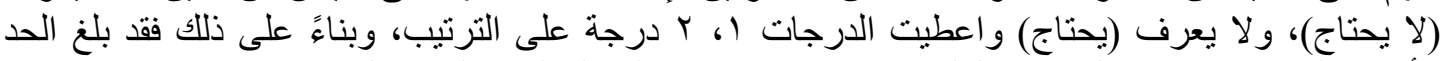

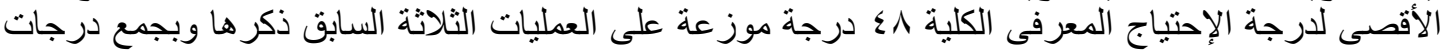

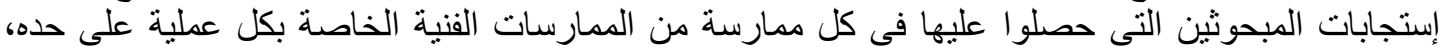

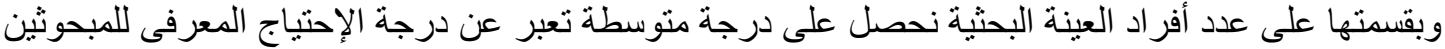

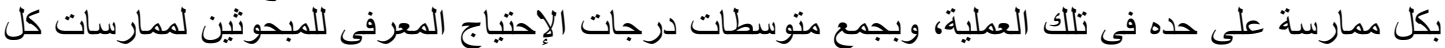

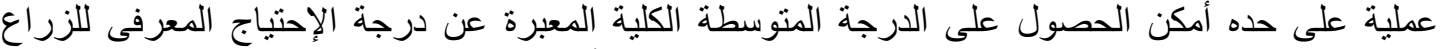

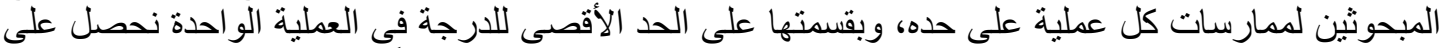

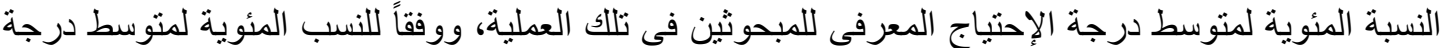

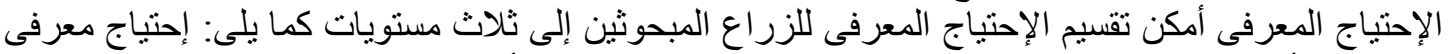

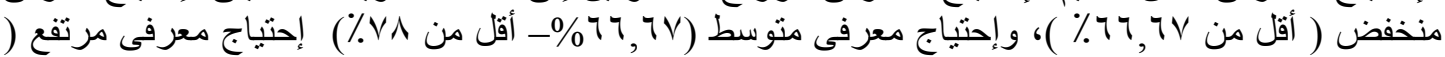

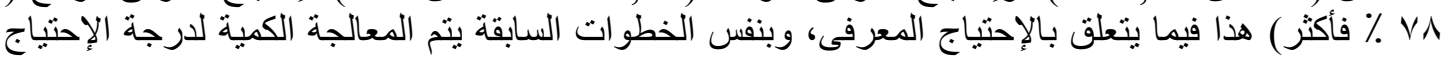

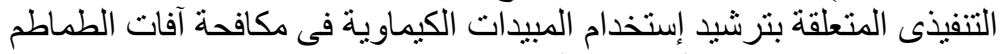
ج- الخدمات الإرشادية المقدمة من جهاز الإرشاد الزئل الزراعى لترشيد إستخدام المبيدات الكيماوية فى

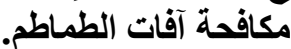

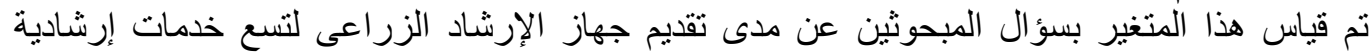

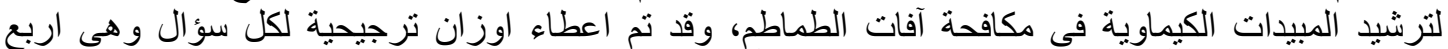

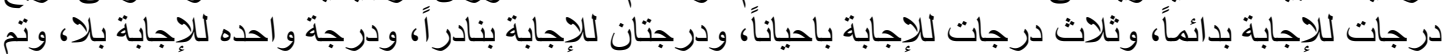

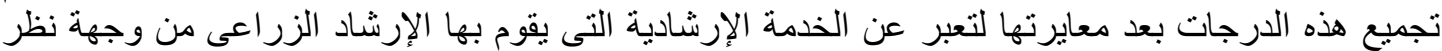

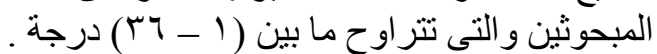

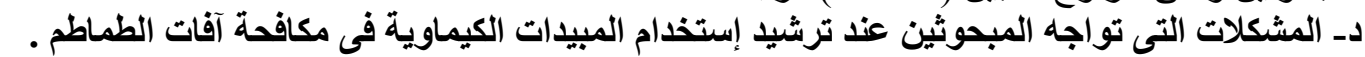

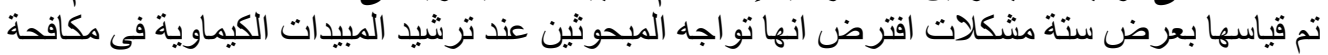

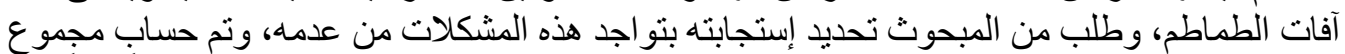

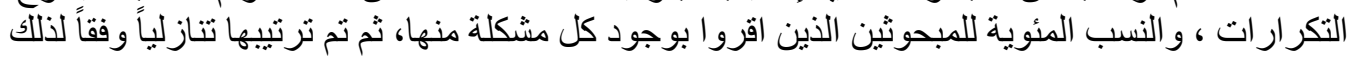

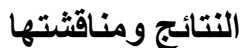
اولاً: الخصائص المميزه للزراع المبحوثين

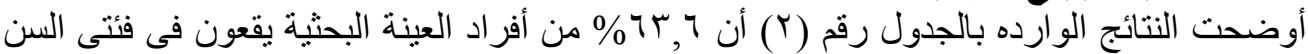

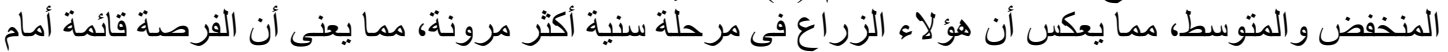

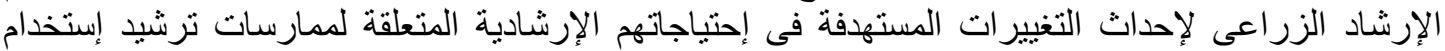

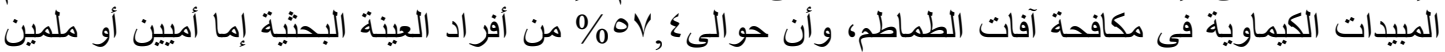

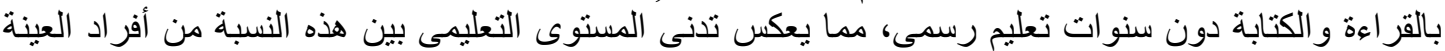

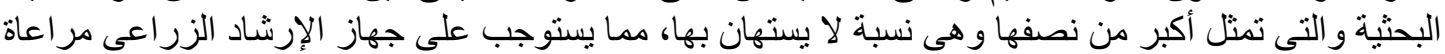

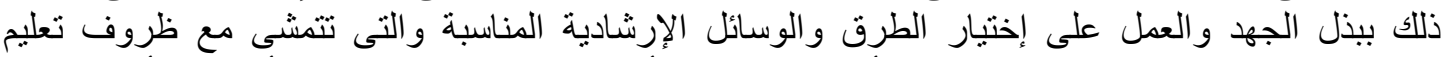

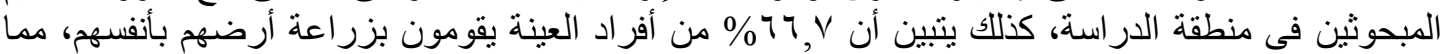

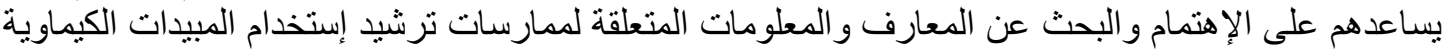

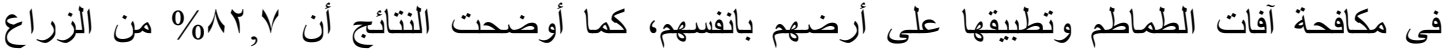

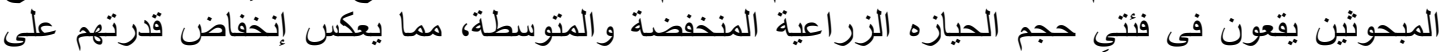

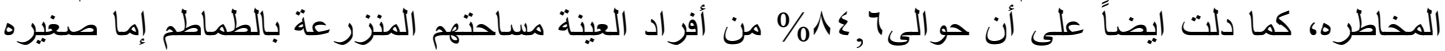

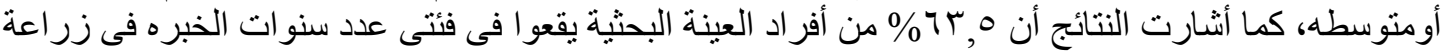

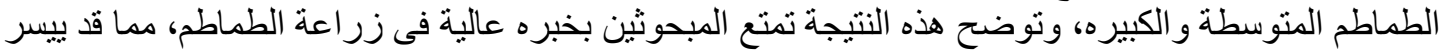

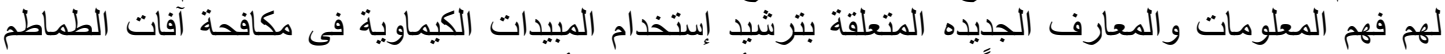

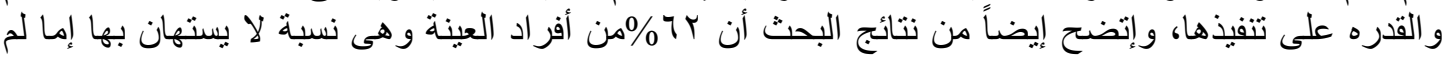

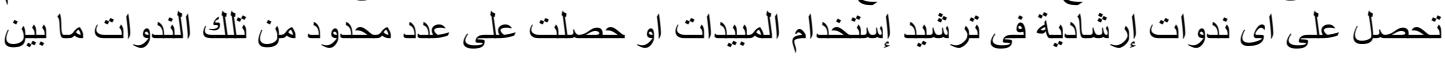

Fayoum J. Agric. Res. \& Dev., Vol. 34, No.2 July, 2020 


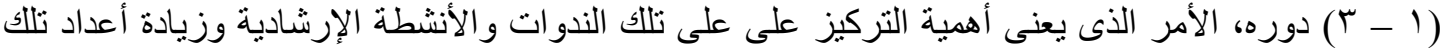

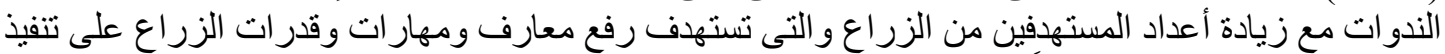

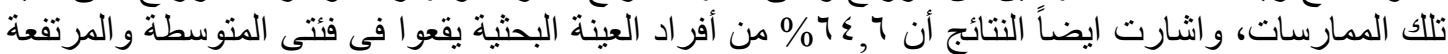

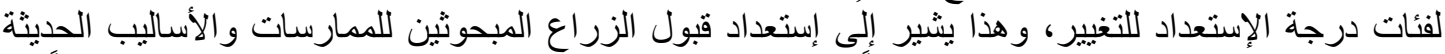

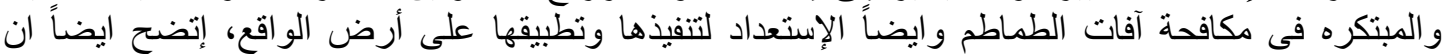

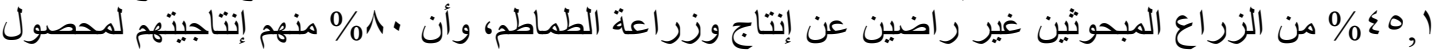

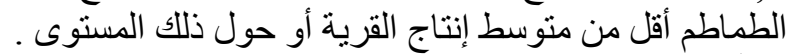

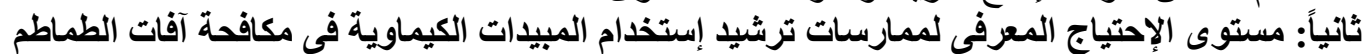

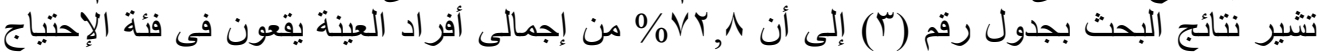

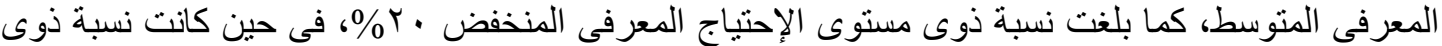

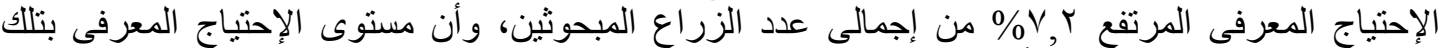

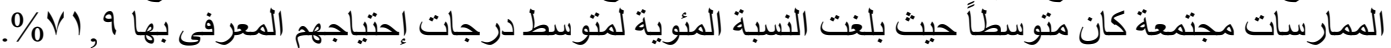

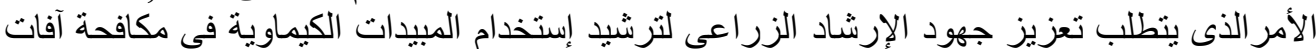

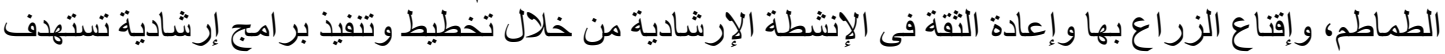

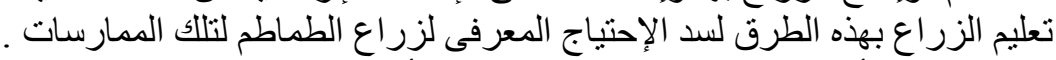

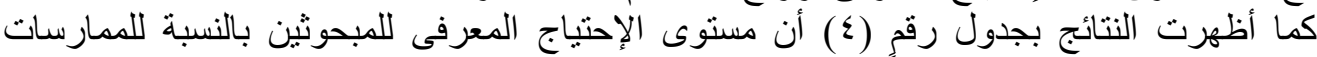

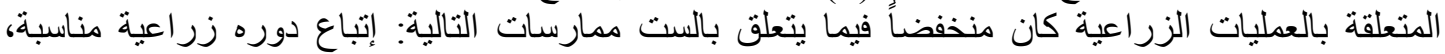

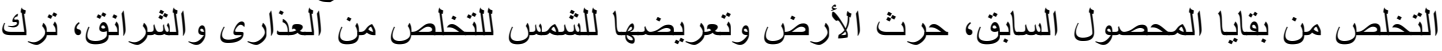

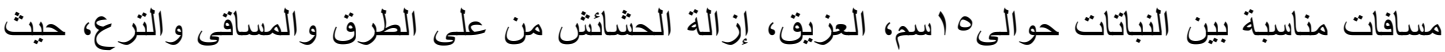

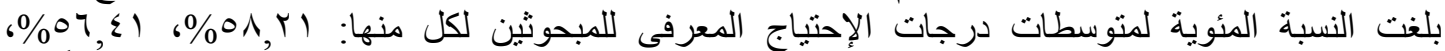

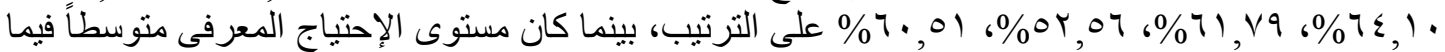

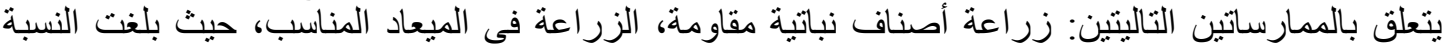

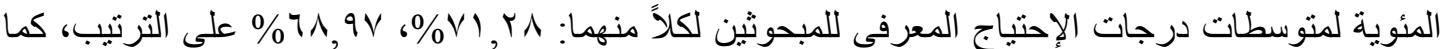

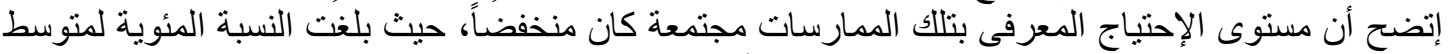

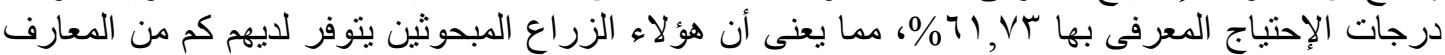

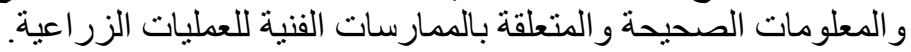

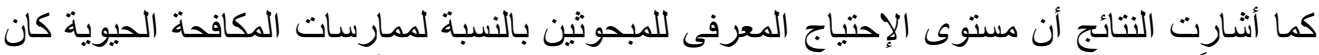

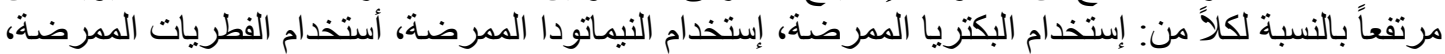

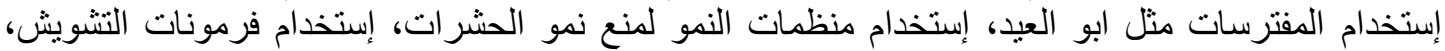

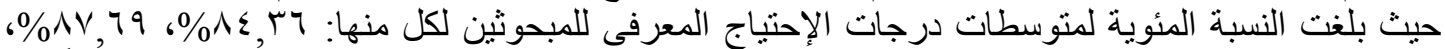

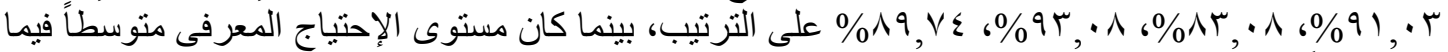

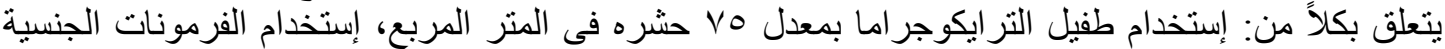

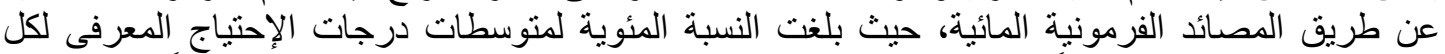

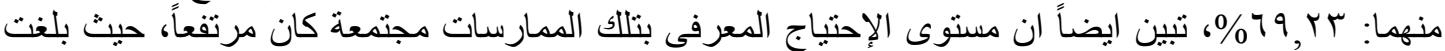

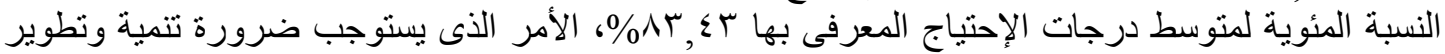

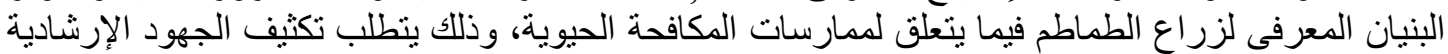

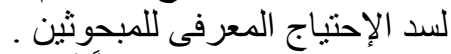
بينت النتائج ايضاً أن مستوى الإحتياج المعرفى للزر التهاع المبحوثين بالنسبة للممارسات المتعلقة ببدائل

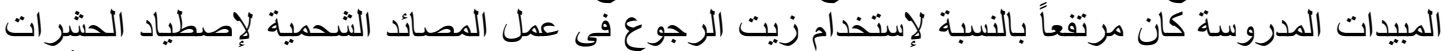

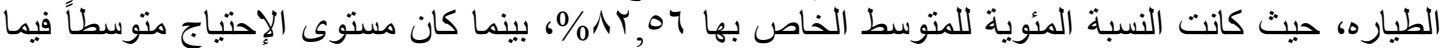

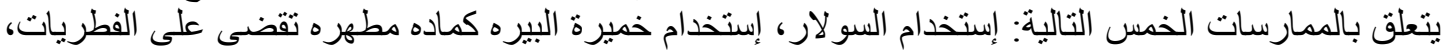

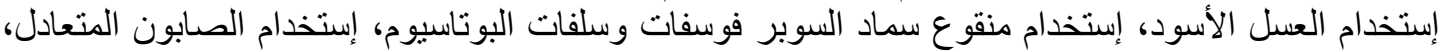

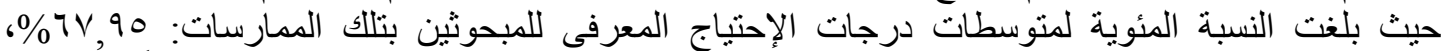

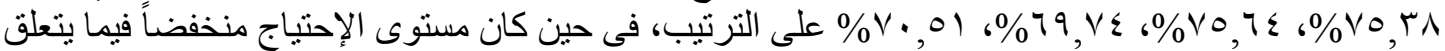

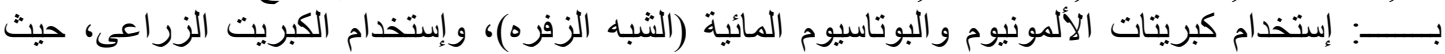

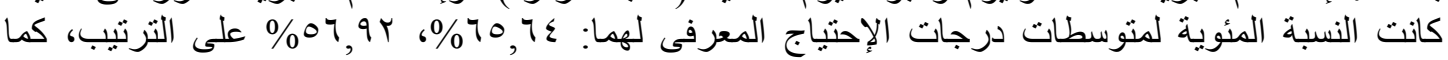

Fayoum J. Agric. Res. \& Dev., Vol. 34, No.2 July, 2020 


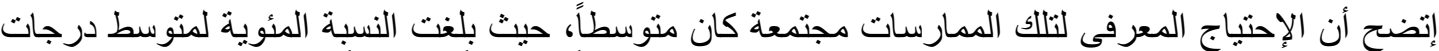

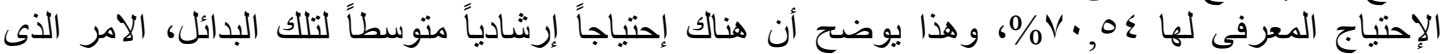

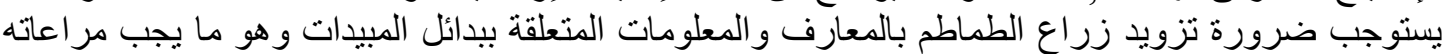

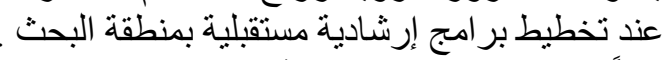

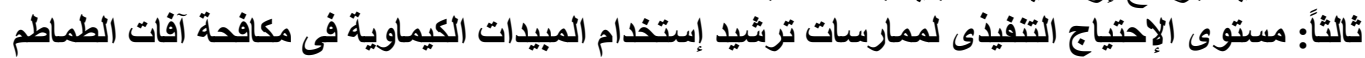

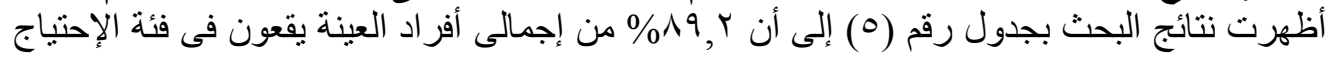

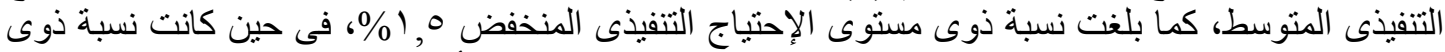

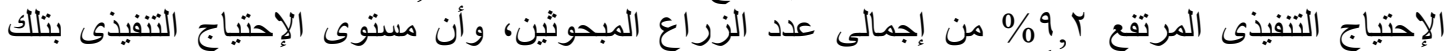

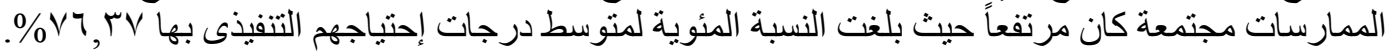

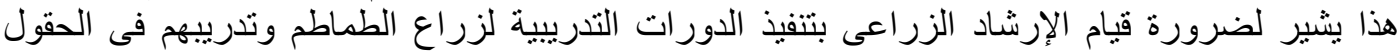

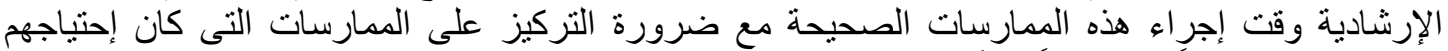

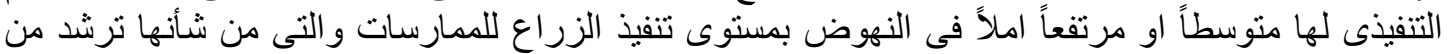

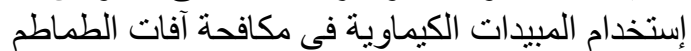

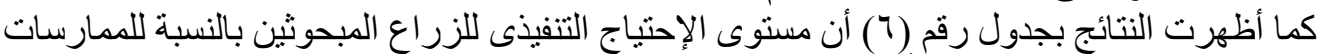

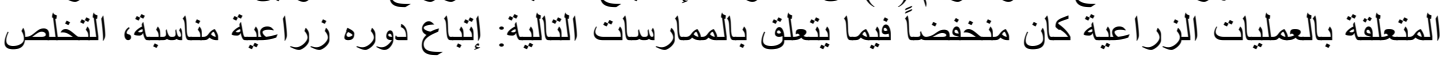

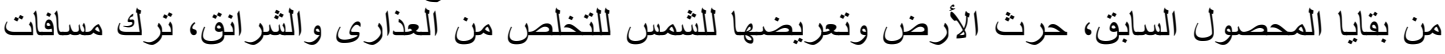

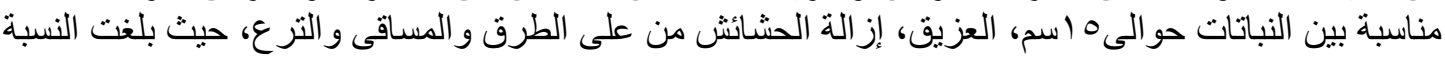

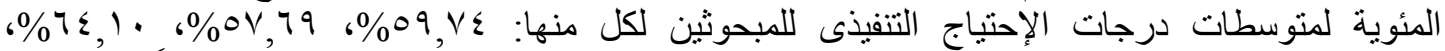

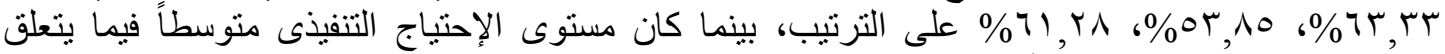

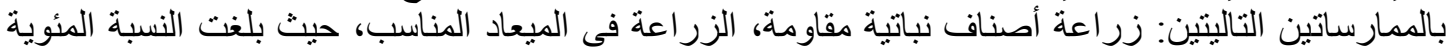

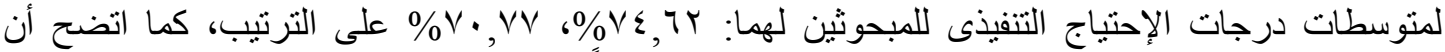

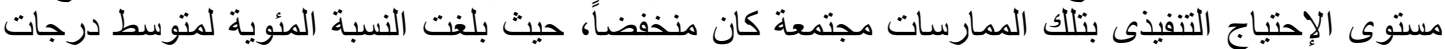

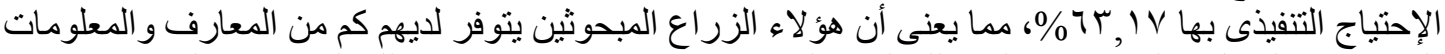

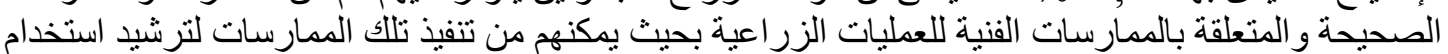

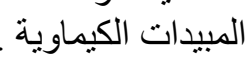

كما إتضح من النتائج أن مستوى الإحتباج التنفيذى للمبحوثين بالنسبة لممارسات المكافحة الحيوية كان المبان

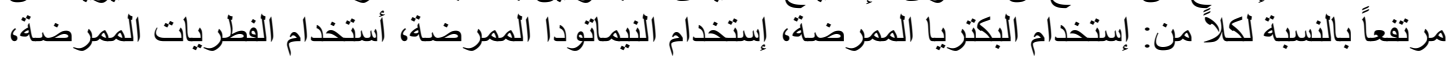

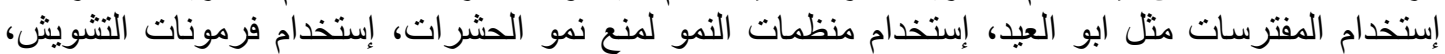

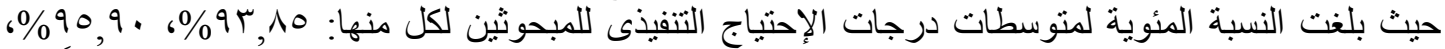
\%

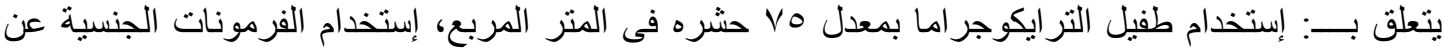

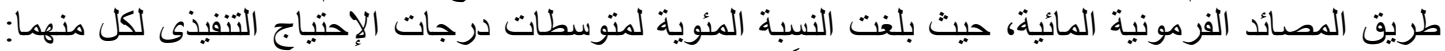

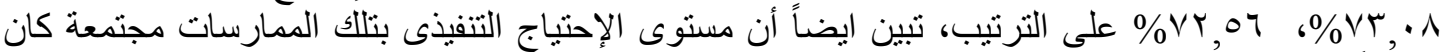

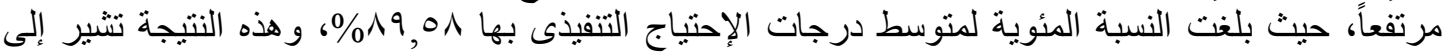

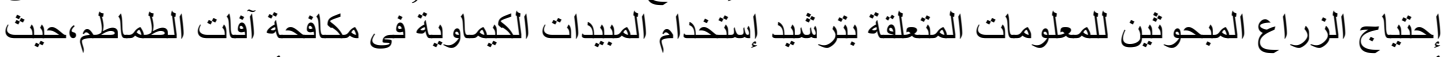

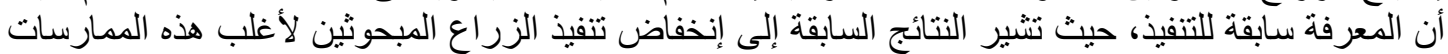

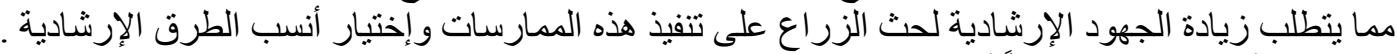

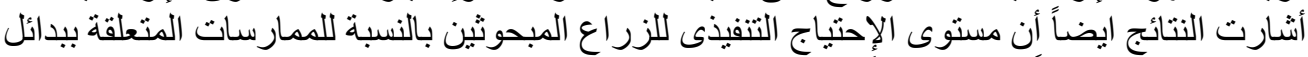

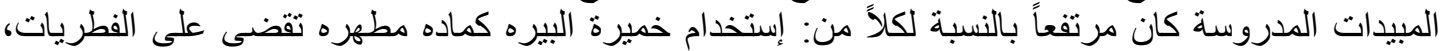

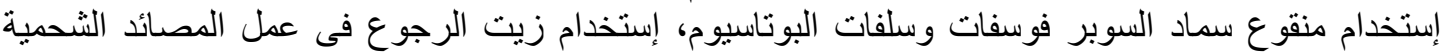

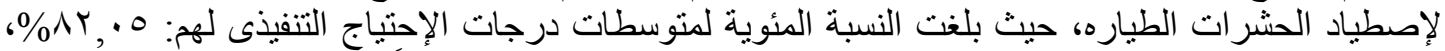

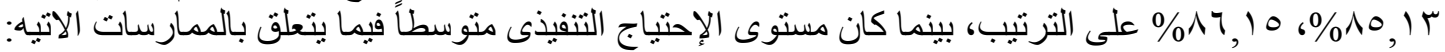

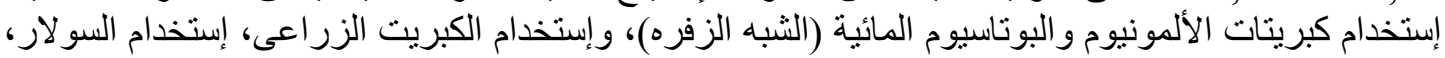

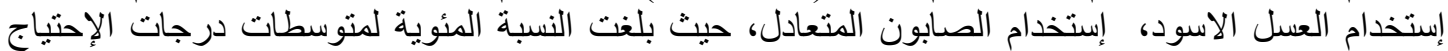

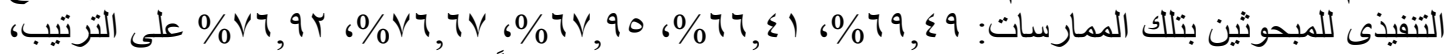

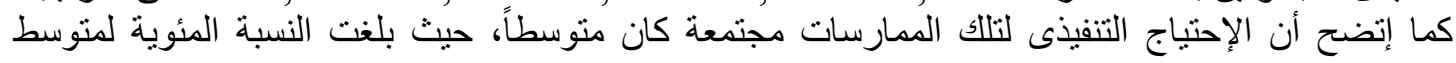

Fayoum J. Agric. Res. \& Dev., Vol. 34, No.2 July, 2020 
纟7

درجات الإحتياج التنفيذى لها هب,\%7\%، الأمر الذى بستلزم معه من جانب القائمين على العمل الإرشادى

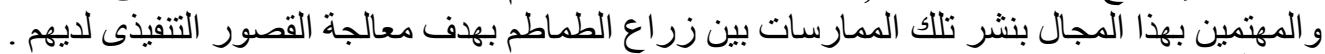

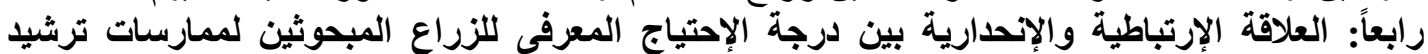

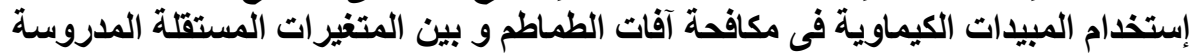

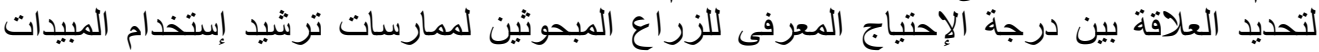

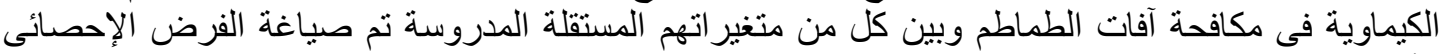

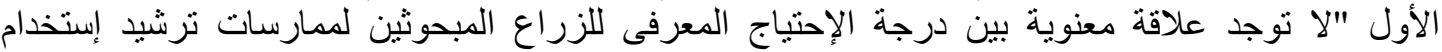

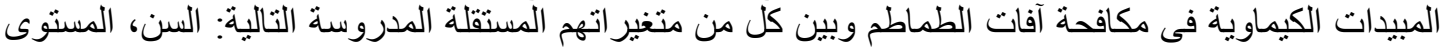

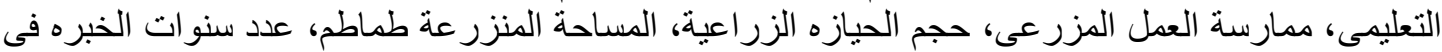

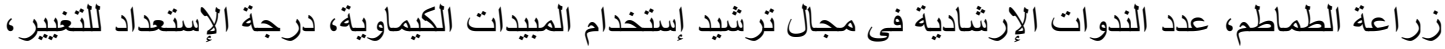

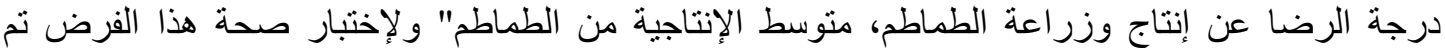

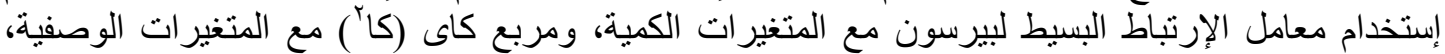

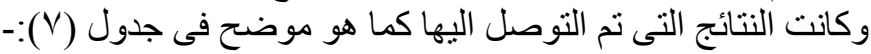

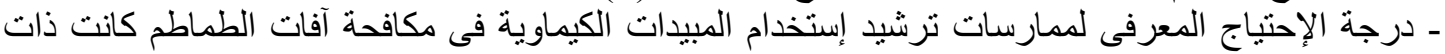

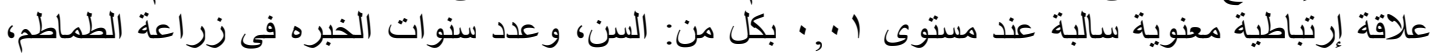

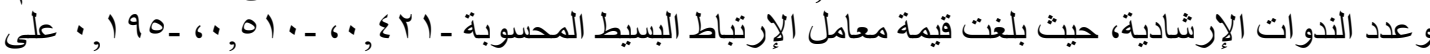

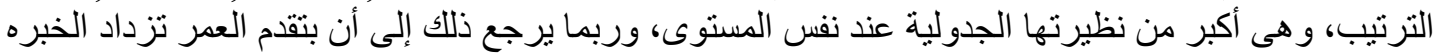

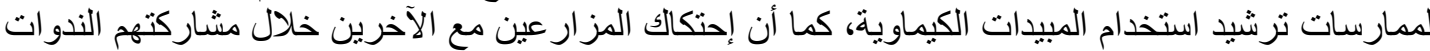

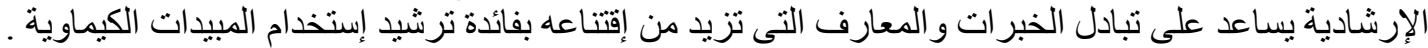

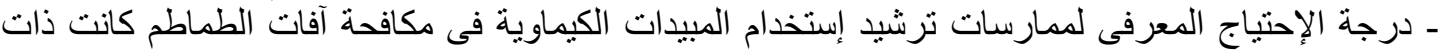

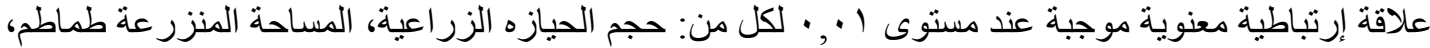

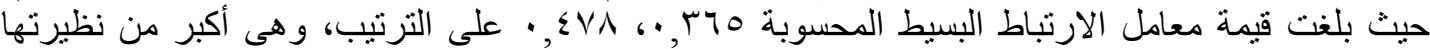

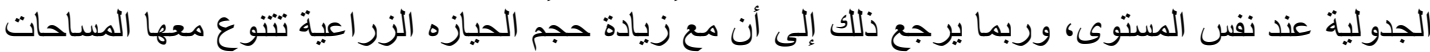

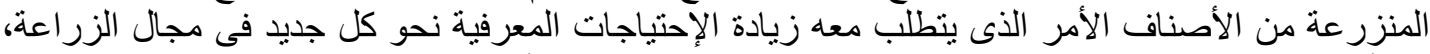

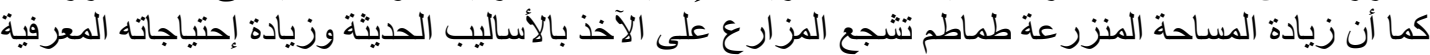

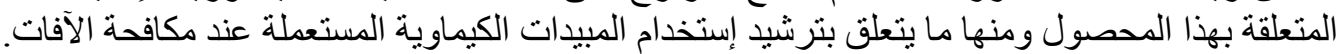

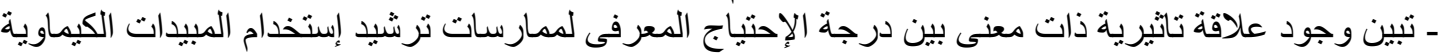

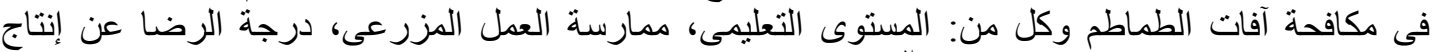

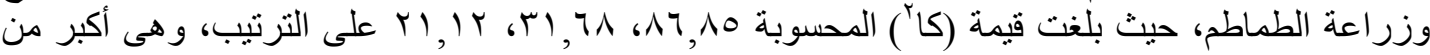

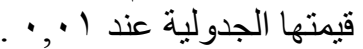

ـ عدم وجود علاقة معنوية بين درجة الإحتباج المعرفى لممارسات ترشيد إستخدام المبيدات الكيماوية فى المئ

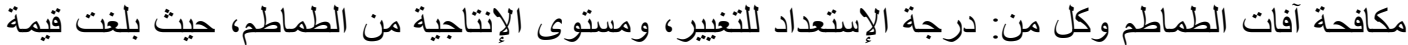

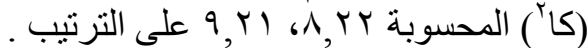

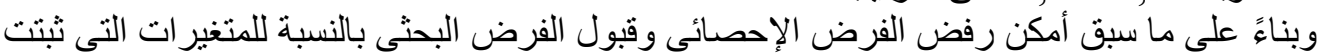

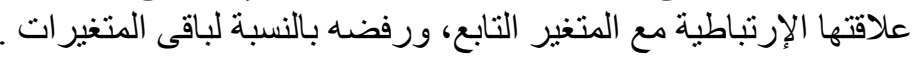

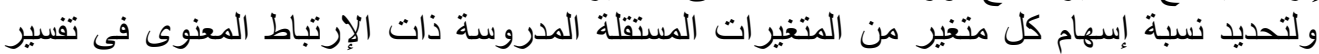

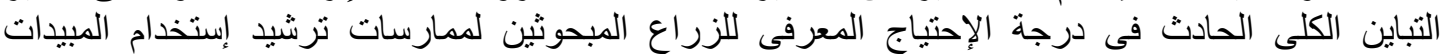

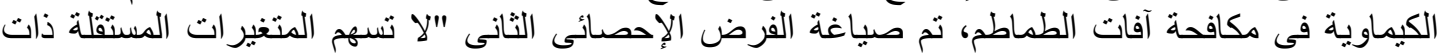

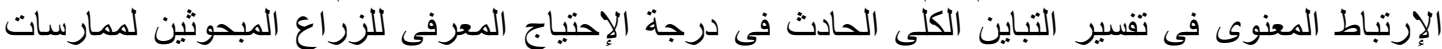

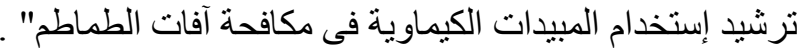

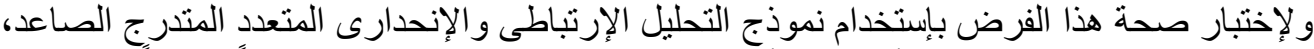

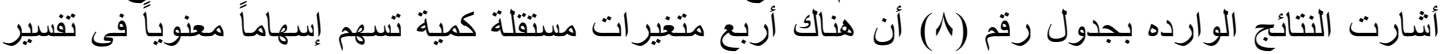

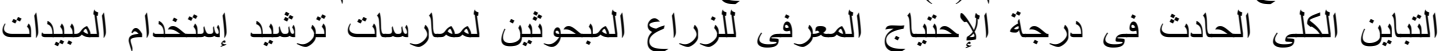

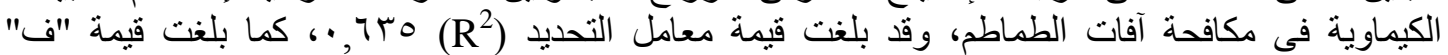

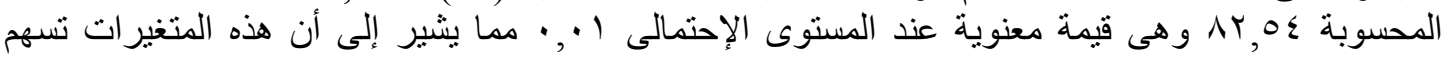

Fayoum J. Agric. Res. \& Dev., Vol. 34, No.2 July, 2020 


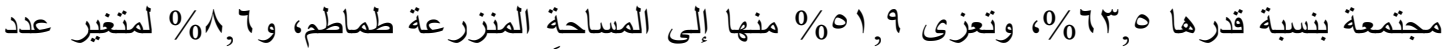

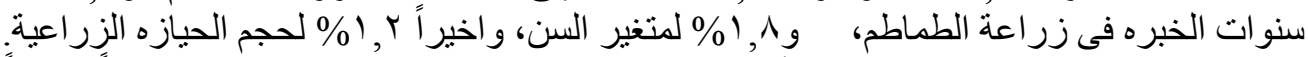

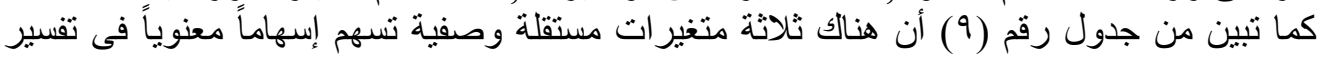

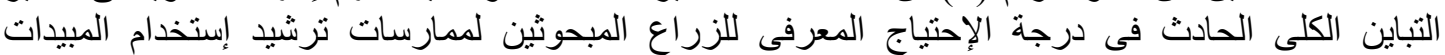

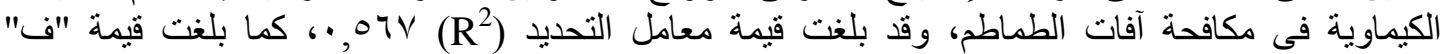

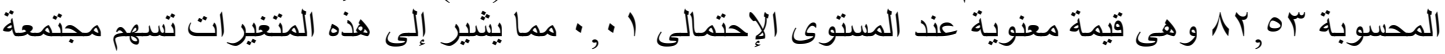

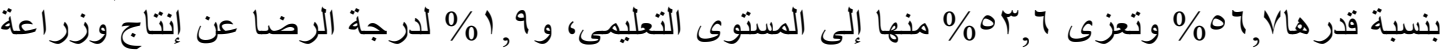

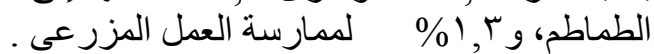

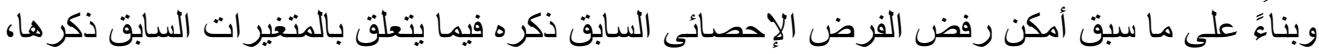

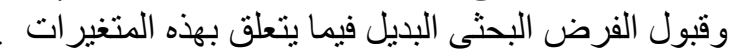

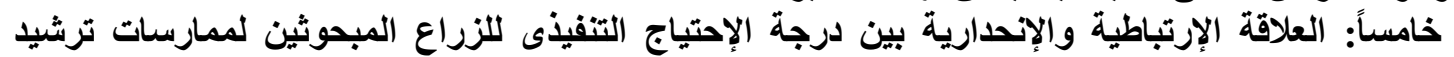

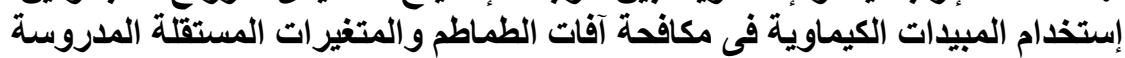

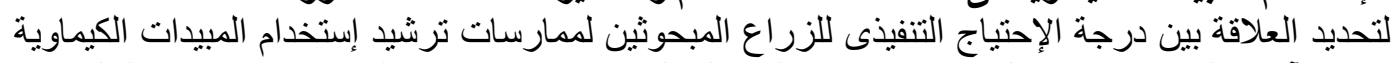

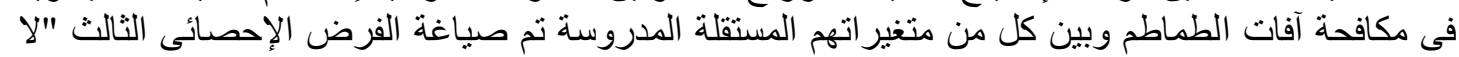

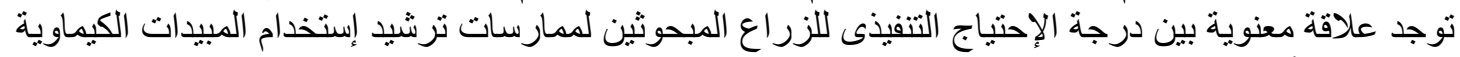

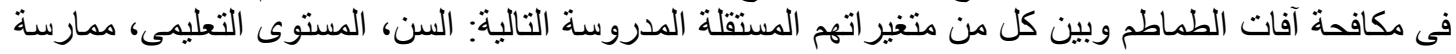

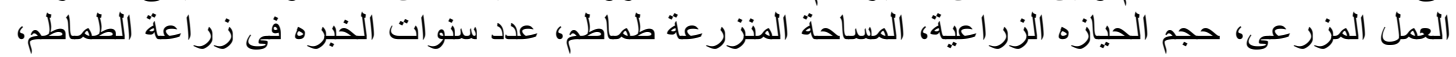

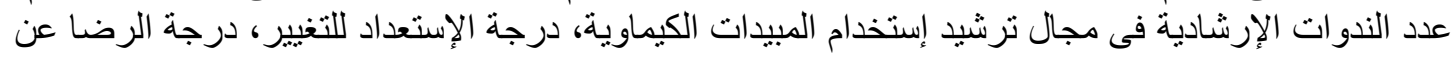

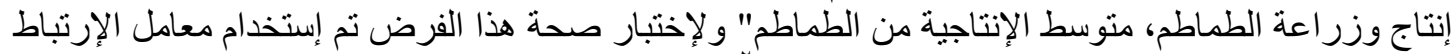

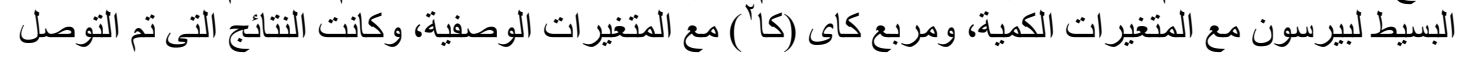

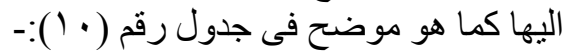

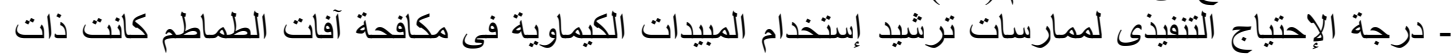

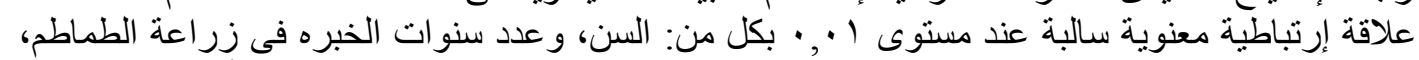

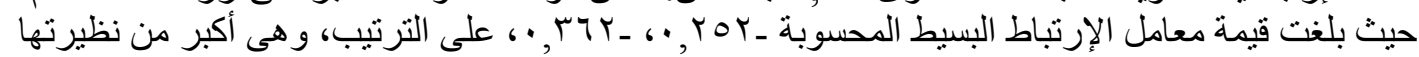

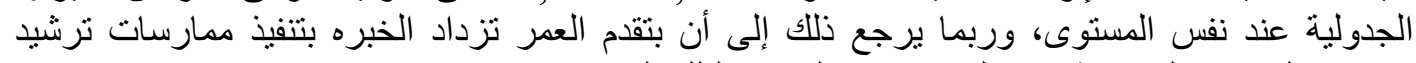

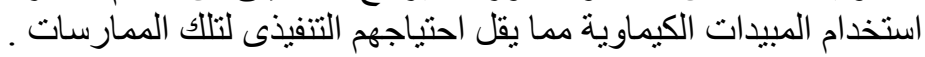

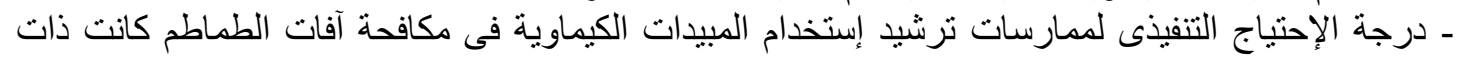

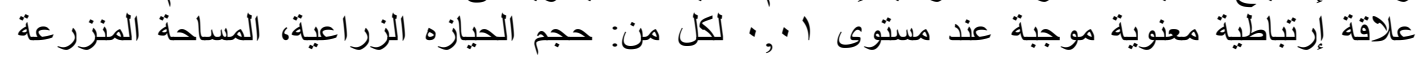

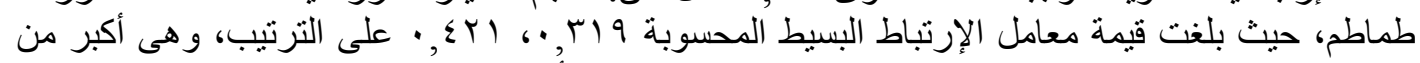

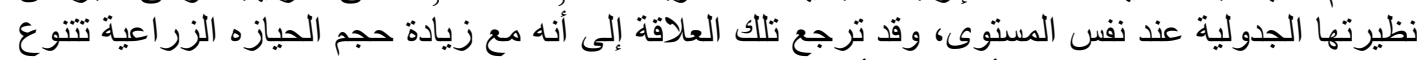

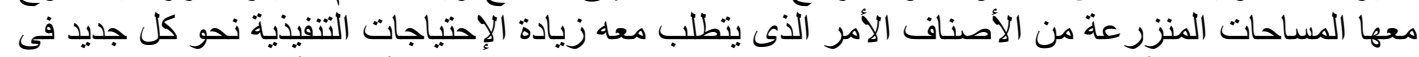

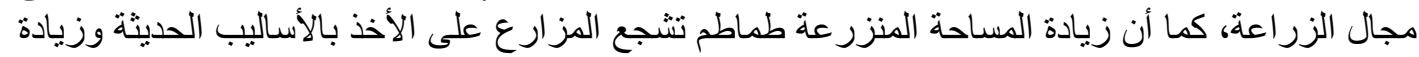

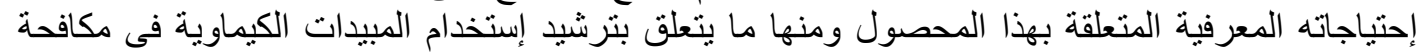

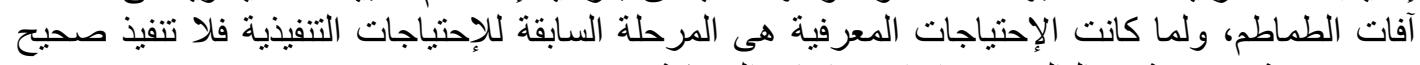

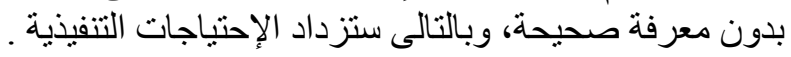

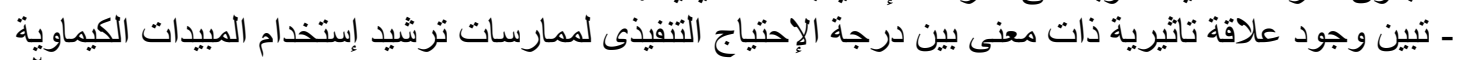

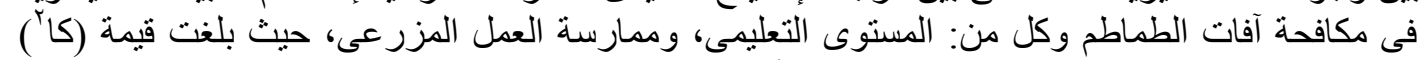

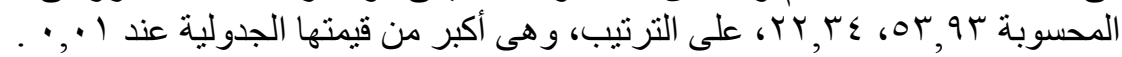

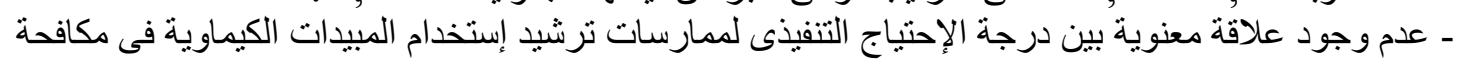

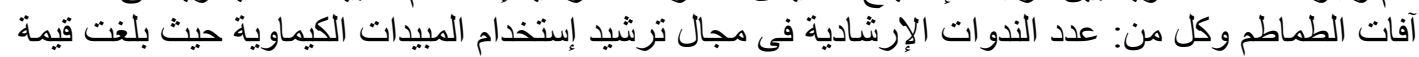

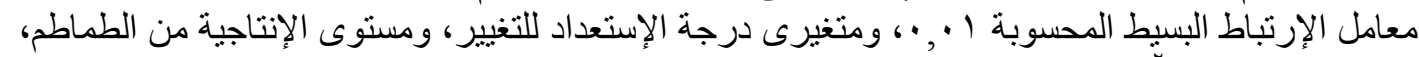

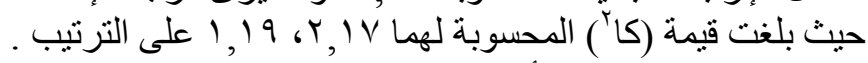

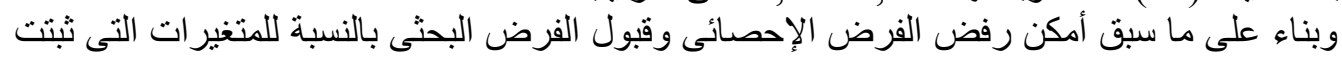

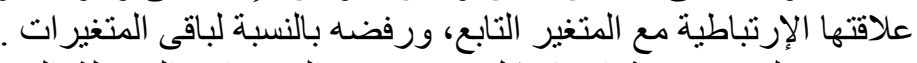

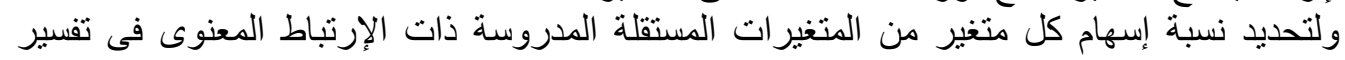

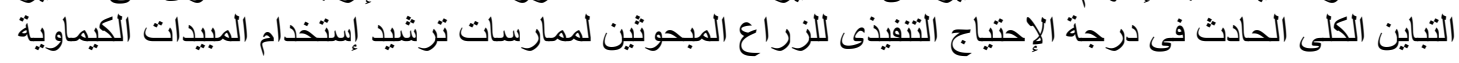

Fayoum J. Agric. Res. \& Dev., Vol. 34, No.2 July, 2020 
$\varepsilon \wedge$

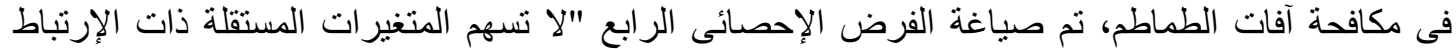

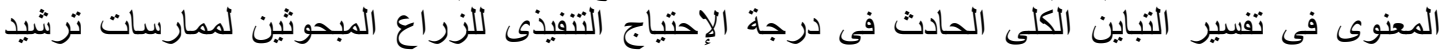

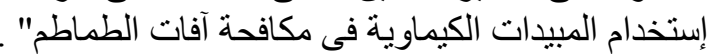

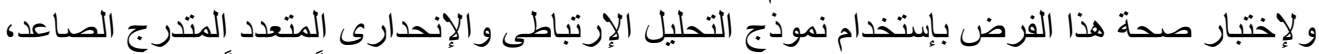

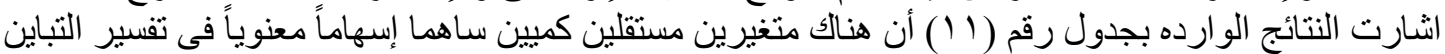

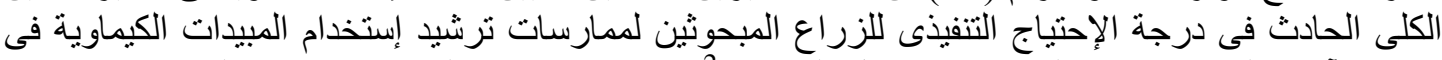

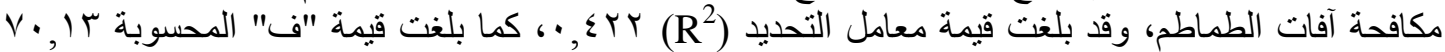

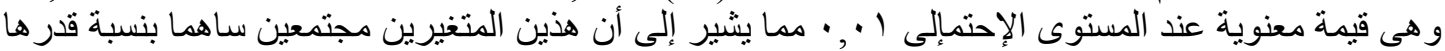

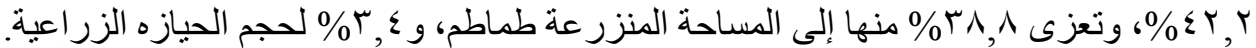

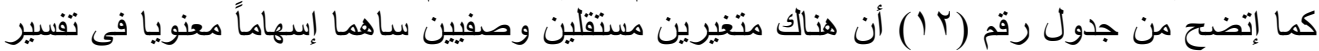

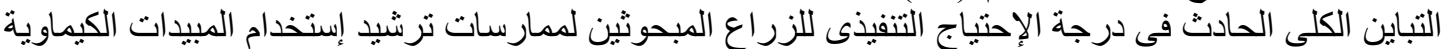

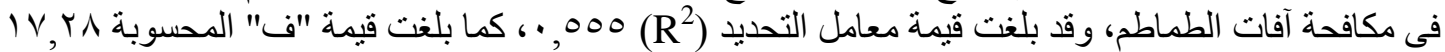

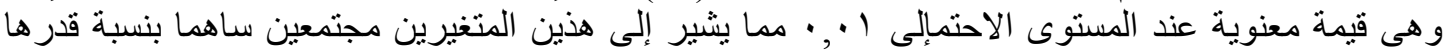

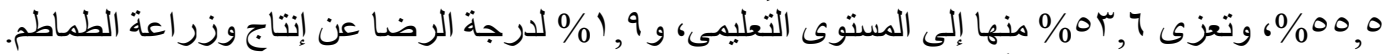

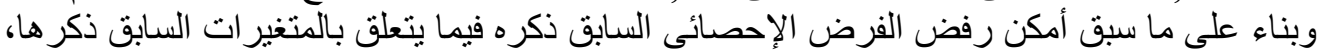

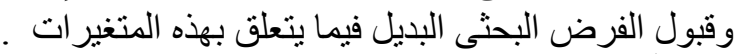

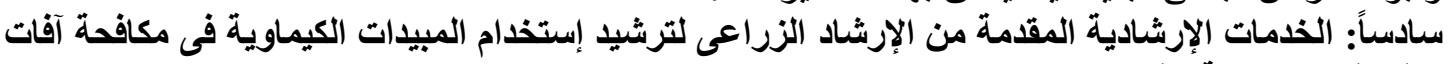

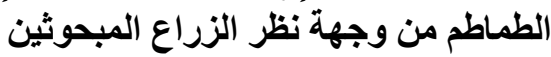

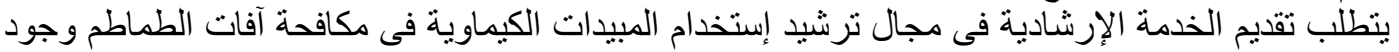

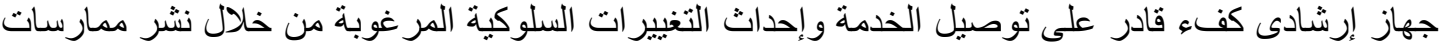

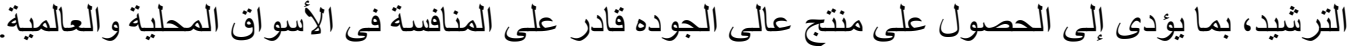

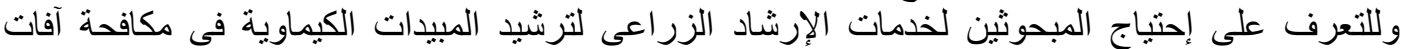

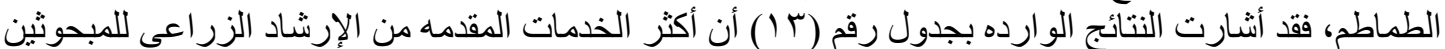

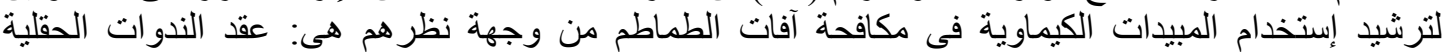

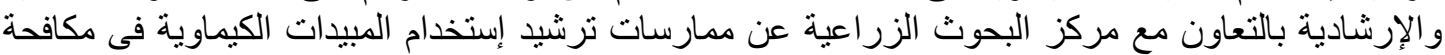

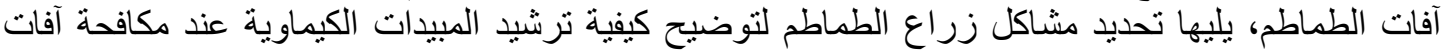

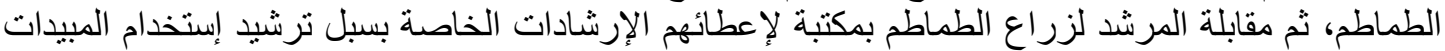

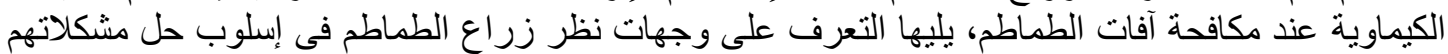

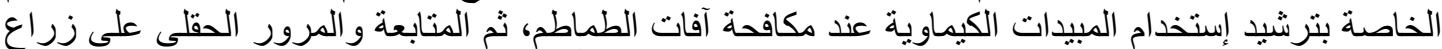

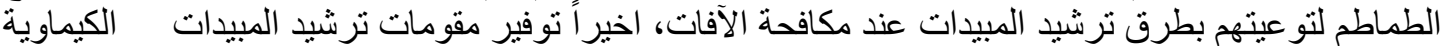

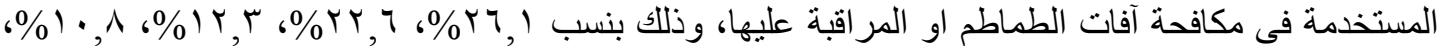

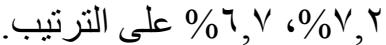
لالنظر إلى الخدمات المقدمة للزراع المباع المبحوثين يتضح الضعف الثديد للخدمات المقدمة من الجهاز الإرشادى

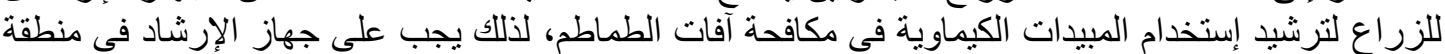

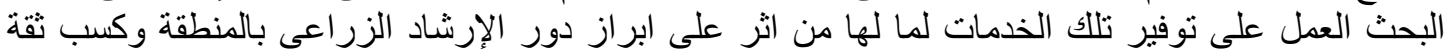

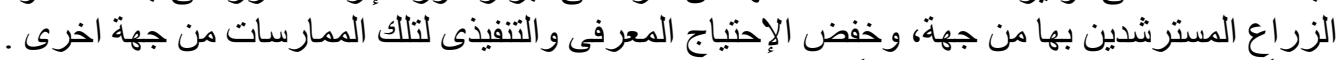

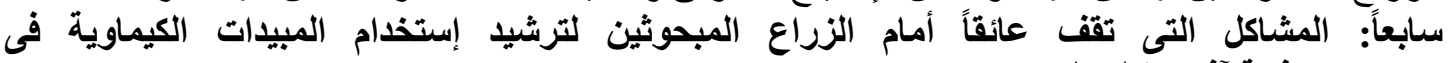
مكافحة آفات الطماطم الفئ

ترجع أهمية دراسة المشاكل التى تواجه الزراع المبحوثين عند ترشيدهم لإستخدام المبيدات الكيماوية

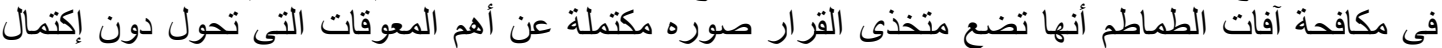

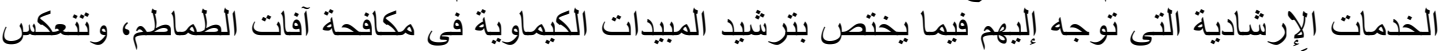

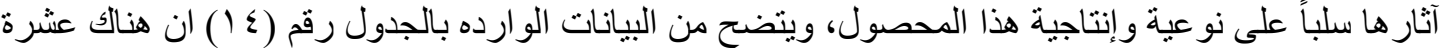

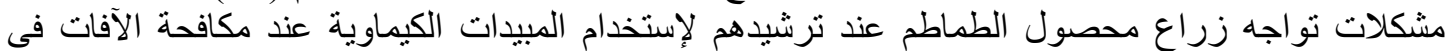

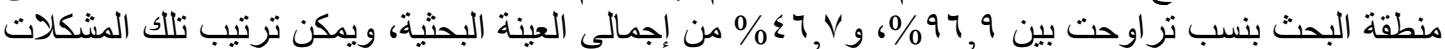

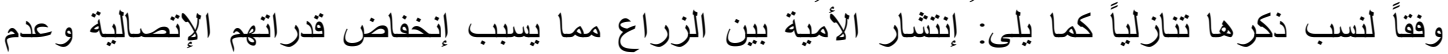

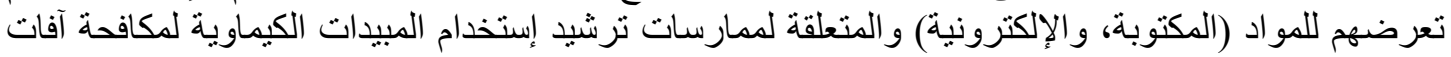

Fayoum J. Agric. Res. \& Dev., Vol. 34, No.2 July, 2020 
$\leqslant 9$

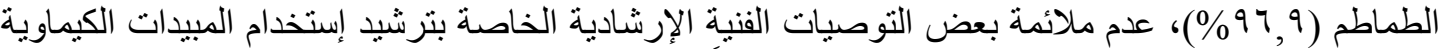

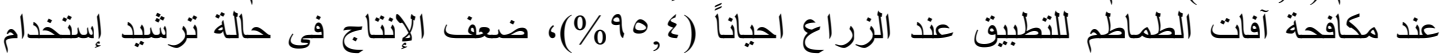

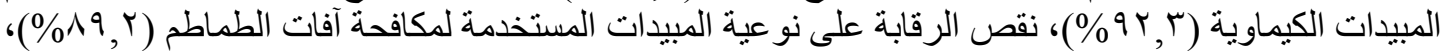

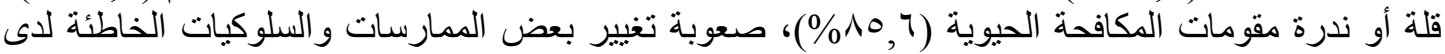

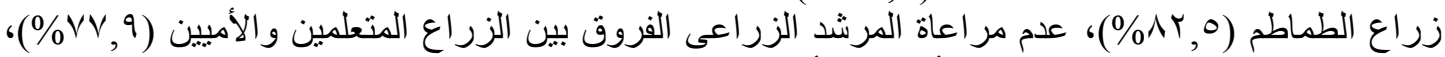

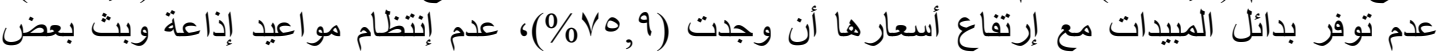

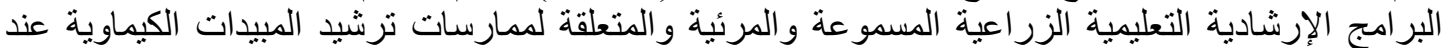

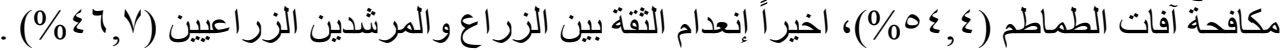
التوصيات التصات ا - إستناداً إلى ما خلصت إليه نتائج البحث من إرتفاع إحتياجات الزراع البهات المبحوثين (المعرفية والتنفيذية)

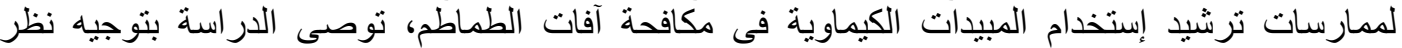

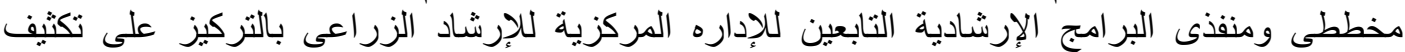

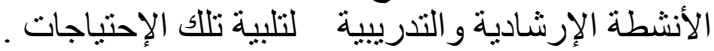

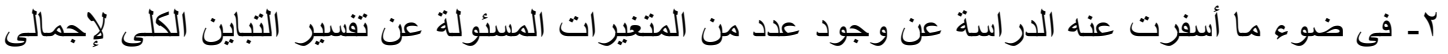

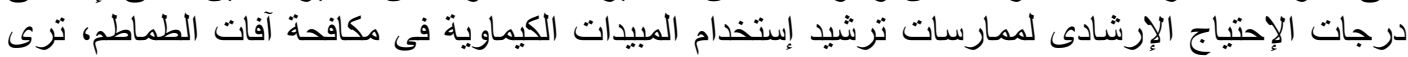

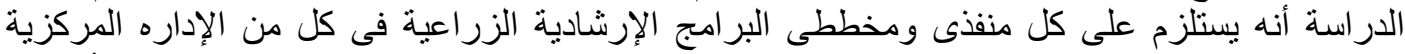

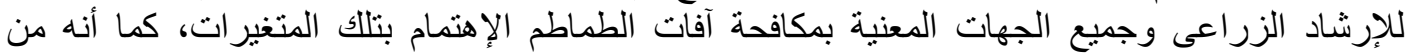

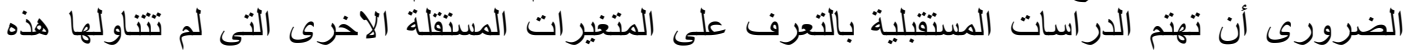

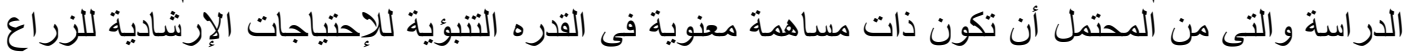

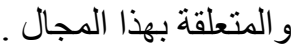

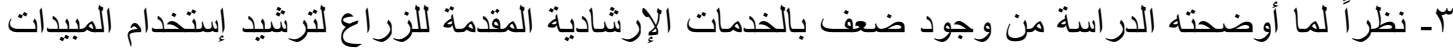

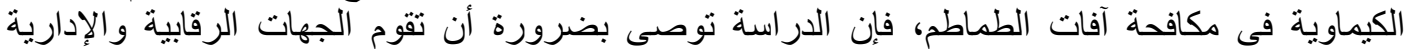

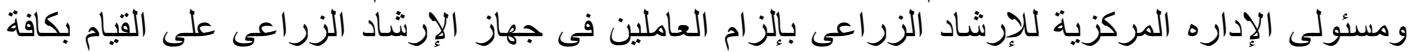

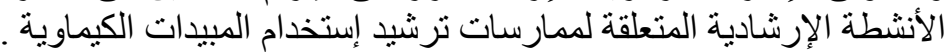

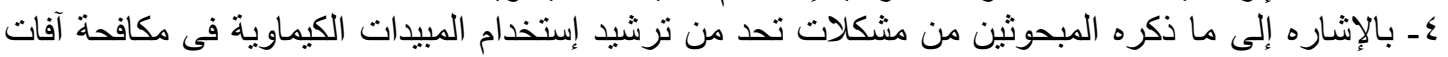

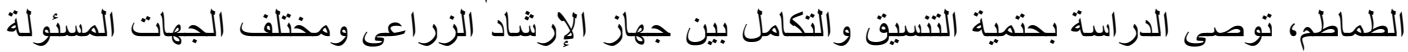

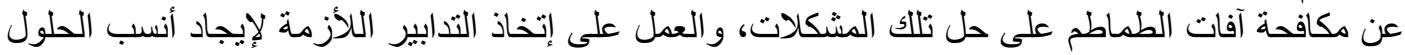

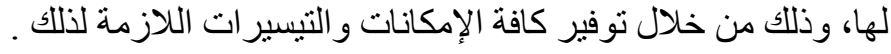

جدول (1) جاملة وعينة البحث

\begin{tabular}{|c|c|c|c|c|}
\hline العينة & الشـاملة & القرى المختاره & المراكز المختاره & 5 \\
\hline $7 \mathrm{~V}$ & $11 \% 0$ & قرية ؛ & سمالوط & $T$ \\
\hline$\varepsilon \wedge$ & 91 & بنى احمد & المنيا & T \\
\hline$\Lambda$. & 174 & دلجا & دير مواس & $r$ \\
\hline 190 & 190 & & & \\
\hline
\end{tabular}

Fayoum J. Agric. Res. \& Dev., Vol. 34, No.2 July, 2020 
0 .

\begin{tabular}{|c|c|c|c|}
\hline & & ثين طبقا لخصائصهم الشخصية & جدول (r): التوزيع العددى والنسبى للمب \\
\hline$\%$ & عدد ن= & الفئات & المتضغيرات \\
\hline $1 \leqslant, 9$ & rq & ) & \multirow{3}{*}{ 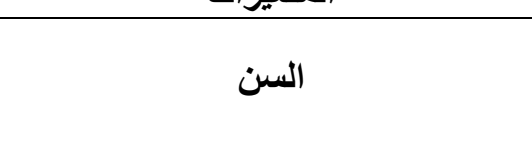 } \\
\hline$\varepsilon \wedge, V$ & 90 & (OV_ - I l) & \\
\hline$\Gamma \uparrow, \xi$ & VI & سنه $(V \Gamma-0 \Lambda)$ & \\
\hline$r T, 7$ & $\leqslant 7$ & أمىى & \multirow{4}{*}{ المستوى التعليمى } \\
\hline$r \mu, \Lambda$ & 77 & يقر اويكتب & \\
\hline rᄉ, & Vo & حاصل على مؤهل متو سط & \\
\hline$\varepsilon, 1$ & $\wedge$ & حاصل على مؤ هل جامعي & \\
\hline $77, \mathrm{~V}$ & $\pi$ & يقو بزر اعة ارضه بنفسهة & \multirow{2}{*}{ ممارسة العمل المزرعى } \\
\hline (1, & 70 & يوكل اخرين فى زر اعة ارضه & \\
\hline $0 \cdot, \xi$ & $9 \wedge$ & حيازه صغيره (اقل من ا) فدان & \multirow{3}{*}{ حجم الحيازه الزراعية } \\
\hline retr & 74 & حيازه متوسطة (من ( - ب) فدان & \\
\hline$T V, \varepsilon$ & ए纟 & حيازه كبيره (اكثر من r) فدان & \\
\hline$\leqslant 0,1$ & $\Lambda \Lambda$ & مساحة صغيره (اقل من () فدان & \multirow{3}{*}{ المساحة المنزر عة طماطم } \\
\hline rq,o & $\overline{V V}$ & مساحة متوسطة (من I - ؟) فدان & \\
\hline $10, \xi$ & $r \cdot$ & مساحة كبيره (اكثر من ؟) فدان & \\
\hline$r 7, \varepsilon$ & VI & خبره قليلة (r - • (1) سنه & \multirow{3}{*}{ عدد سنوات الخبره فى زراعة الطماطم } \\
\hline$r \mu, \Lambda$ & 77 & خبره منوسطة (11 - 19) سنه & \\
\hline Yq,V & 01 & خبره كبيره (اكثر من • r) سنه & \\
\hline TV, & $V_{T}$ & لا بوجد & \multirow{4}{*}{ عدد الندوات الإرشادية في مجالية ترشيداد الكيات } \\
\hline$T \leqslant, 7$ & $\varepsilon \wedge$ & ) ندوه & \\
\hline Y Y,,$Y$ & 01 & ( & \\
\hline 11,1 & TT & ند $(9-V)$ & \\
\hline ro, & 79 & منخفضة (7 - 9) درجه & \multirow{3}{*}{ درجة الإستعداد للتغيير } \\
\hline$\leqslant 7, V$ & 91 & متوسطة (· (1 ـ أ) درجة & \\
\hline $1 v, 9$ & To & مرتفعة (10 - 1 1 (1) درجة & \\
\hline$\leqslant 0,1$ & $\Lambda \wedge$ & غير راضى & \multirow{3}{*}{ درجة الرضا عن انتاج وزراعة الطماطم } \\
\hline r7, & VI & ر راضى لحد ما & \\
\hline 11,0 & rT & راضى تماما & \\
\hline$\Sigma \cdot, 0$ & $\mathrm{V9}$ & أَلّ من متوسط انتاج القرية & \multirow{3}{*}{ مستوى الإنتاجية من الطماطم } \\
\hline$r 9,0$ & VV & حول المتوسط & \\
\hline$r \cdot, \cdot$ & rq & اعلى من المنوسط & \\
\hline
\end{tabular}

جدول (ب): توزيع المبحوثين وفقاً لمستوى الإحتياج المعرفى بترشيد إستخدام المبيدات الكيماوية فى مكافحةً

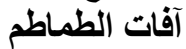

\begin{tabular}{|c|c|c|c|c|c|c|}
\hline المستوى & $\begin{array}{c}\% \\
\text { للمتوسط }\end{array}$ & الالانحراف & الحسابي & $\%$ & عدد & مستوى الإحتياج المعرفى \\
\hline & & & & $r$. & $r q$ & منخفض (צ ץ - آץ) درجة \\
\hline & & & & $\overline{V T, \Lambda}$ & $1 \leqslant r$ & متوسط (r r - · ع ) درجة \\
\hline & & & & $V, r$ & $1 \leqslant$ & مرتفع (1؛ - ^ §) درجة \\
\hline متوسط & V), q. & $\cdot, \leqslant \mu_{0}$ & $1, \leqslant \varepsilon$ & $1 \cdots$ & 190 & المجموع \\
\hline
\end{tabular}

Fayoum J. Agric. Res. \& Dev., Vol. 34, No.2 July, 2020 
01

جدول (ع): توزيع المبحوثين وفقاً للاحتياج المعرفى بترشيد إستخدام المبيدات الكيماوية فى مكافحة آفات

الطماطم

\begin{tabular}{|c|c|c|c|c|c|}
\hline 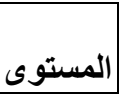 & \begin{tabular}{|c|}
$\%$ \\
\% للمتوسط \\
\end{tabular} & الالمعرافيارى & المستوسطى المسابع & التوصيات & r \\
\hline \multicolumn{6}{|c|}{ بالنسبة للعمليات الزراعية } \\
\hline منخفض & $0 \wedge, Y 1$ & $\cdot \operatorname{rVI}$ & 1,17 & إتباع دور ه زر اعية مناسبة & 1 \\
\hline منخفض & $07, \leqslant 1$ & ס סוr, & 1,11 & |التخلص من بقايا المحصول السابق & r \\
\hline منخفض & $7 \varepsilon, 1 \cdot$ & $\cdot, \leqslant 01$ & $1, r \wedge$ & حرث الارض وتعريضها للشمس للتخلص من العذارى و الثر انق & $r$ \\
\hline متوسط & $\vee, Y \wedge$ & $\cdot, \leqslant 97$ & $1, \leqslant T$ & زر اعة اصناف نباتية مقاومهه & $\varepsilon$ \\
\hline 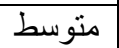 & $7 \wedge, 9 V$ & $\cdot, \leqslant \wedge V$ & $1, \Gamma \wedge$ & |الزر اعة فى الميعاد المناسب & 0 \\
\hline منخفض & 71,199 & $\cdot, \leqslant Y T$ & $1, Y \varepsilon$ & تزرك مسآفات مناسبة بين النباتات حو الى ه اسم & 7 \\
\hline منخفض & $0 Y, 0 T$ & $\cdot, Y Y_{1}$ & 1,0 & |العزيق & V \\
\hline منخفض & $7 \cdot, 01$ & $\cdot, \varepsilon \cdot 9$ & $1, Y 1$ & |زاز الة الحشائش من على الطرق و المساقى و الترع & $\Lambda$ \\
\hline منخفض & 7), $\mathrm{VT}$ & $\cdot, r 99$ & $1, Y$ & إجمالى الإحتياج المعرفي للعمليات الزر اعية & \\
\hline \multicolumn{6}{|c|}{ ال بالنسبة للمكافحة الحيوية } \\
\hline 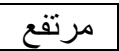 & 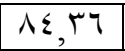 & $\cdot, \leqslant 70$ & 1,79 & |إستخدام البكتيريا الممرضة & 9 \\
\hline مرتفع & $\Lambda \vee, 79$ & $\cdot, \varepsilon r r$ & 1,10 & |إستخدام النيماتودا الممرضة & $1 \cdot$ \\
\hline مرتفع & $91, \cdot r$ & $\cdot$ r rAO & $1, \wedge r$ & إستخدام الفطريات الممرضة & 11 \\
\hline مرتفع & Ar, $\cdot \Lambda$ & $\cdot, \leqslant \vee \leqslant$ & 1,77 & |إستخدام المفترسات مثل ابو العيد & IT \\
\hline 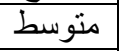 & $79, Y T$ & $\cdot, \leqslant \wedge \wedge$ & $1, \Gamma \wedge$ & إستخدام طفيل التر ايكوجر اما بمعدل 0 حشره في المتر المربع & $1 \pi$ \\
\hline مرتفع & 94,1 & $\cdot, r \leqslant 7$ & $1, \wedge 7$ & إستخدام منظمات النمو لمنع نمو الحشره & $1 \varepsilon$ \\
\hline مرتفع & $\wedge 9, \vee \leqslant$ & $\cdot, \varepsilon \cdot 0$ & 1,199 & |إستخدام فرمونات التشويش & 10 \\
\hline منوسط & $79, Y T$ & $\cdot, \leqslant \wedge \wedge$ & I, rᄉ & إستخدام الفرمونات الجنسية عن طريق المصائد الفرمونية المائية & 17 \\
\hline مرتفع & $\Delta r, \varepsilon r$ & $\cdot, \leqslant$ ro & $1,7 V$ & إجمالى الإحتياج المعرفى للمكافحة الحيوية & \\
\hline \multicolumn{6}{|c|}{ بالنسبة لبدائل المبيدات } \\
\hline 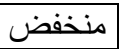 & $70,7 \varepsilon$ & $\cdot, \leqslant 70$ & $1, \mathrm{r}$ & إستخدام كبريتات الالومونيوم و البوتاسيوم المائية (الثبة الزفره) & 19 \\
\hline منخفض & 07,94 & $\cdot, r \leqslant \tau$ & $1,1 \leqslant$ & إستخدام الكبريت الزر اعى & 11 \\
\hline 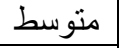 & $7 V, 90$ & $\cdot, \leqslant \wedge 1$ & 1,1 & إستخدام السو لار إن & 19 \\
\hline متوسط & $\vee \vee, \Gamma \Lambda$ & $\cdot, 0.1$ & 1,01 & إستخدام خميره البيره كمادة مطهره تقضى على الفطريات & $r$. \\
\hline متوسط & $V 0,7 \varepsilon$ &., 0.1 & 1,01 & |إستخدام العسل الاسود & Y) \\
\hline متوسط & $79, \vee \leqslant$ & $\cdot, \leqslant 9$. & $1, r q$ & إستخدام منقوع سماد السوبر فوسفات وسلفات البوتاسيوم & YY \\
\hline 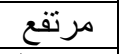 & $\Delta Y, 0 T$ & $\cdot, \leqslant \vee \wedge$ & 1,70 & إستخدام زيت الرجوع فى عمل المصائد الشحمية لإصطياد الحشر ات الطياره & TM \\
\hline متوسط & $V \cdot, 01$ & $\cdot, \leqslant 94$ & $1, \leqslant 1$ & إستخدام الصابون المتعادل & $r \xi$ \\
\hline 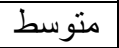 & $V \cdot, 0 \leqslant$ & $\cdot, \leqslant 79$ & $1, \leqslant 1$ & إجمالى الإحتياج المعرفي لبدائل المبيدات & \\
\hline 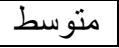 & $v 1,9$. & $\cdot, \leqslant$ ro & $1, \varepsilon \varepsilon$ & المستوى العام & \\
\hline
\end{tabular}

جدول (0): توزيع المبحوثين وفقا لمستوى الإحتياج التنفيذى بترشيد إستخدام المبيدات الكيماوية فى مكافحة آنات الطماطد

\begin{tabular}{|c|c|c|c|c|c|c|}
\hline المستوى & $\begin{array}{c}\text { \% } \\
\end{array}$ & المعياري & الحستوبي & $\%$ & عدد & مستوى الإحتياج التنفيذى \\
\hline & & & & 1,0 & 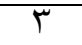 & 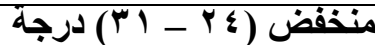 \\
\hline & & & & $\lambda 9, r$ & IV乏 & متوسط (Yr - • \& ) درجة \\
\hline & & & & $9, r$ & 11 & مرتفع (أ ـ - 1 \&) درجة \\
\hline مرتفع & $\mathrm{V}, \mathrm{TV}$ & $\cdot, \leqslant \prod$ & 1,04 & & & ال المجمو \\
\hline
\end{tabular}

Fayoum J. Agric. Res. \& Dev., Vol. 34, No.2 July, 2020 
Or

جدول (1): توزيع المبحوثين وفقا للاحتياج التنفيذى بترشيد إستخام المبيدات الكيماوية فى مكافحة آفات الطماطر

\begin{tabular}{|c|c|c|c|c|c|}
\hline مستو & 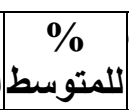 & 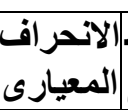 & 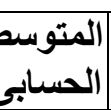 & التوصيات & م \\
\hline & & & & بالنسبة للعمليات الزراعية & \\
\hline منخفض & $09, \mathrm{Y} \varepsilon$ & $\cdot, r 9 \mathrm{~V}$ & 1,19 & إلتباع دوره زر اعية مناسبة & \\
\hline 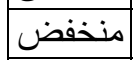 & $0 v, 79$ & 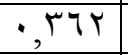 & 1,10 & ألتخلص من بقايا المحصول السابق & \\
\hline 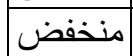 & $7 \varepsilon, 1$. & $\cdot, \leqslant 01$ & $1, \mathrm{Y \Lambda}$ & حرث الارض وتعريضها للثمس للتخلص من العذارى و الثرانق & $r$ \\
\hline 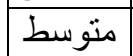 & $V \leqslant, T Y$ &., 0.1 & $1, \leqslant 9$ & زر اعة اصناف نباتية مقاومه & $\varepsilon$ \\
\hline 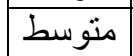 & $V \cdot, V V$ & $\cdot, \leqslant 9 \xi$ & $1, \leqslant T$ & الز الزراعة فى الميعاد المناسب & 0 \\
\hline 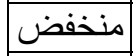 & $7 \Gamma, \Gamma$, & $\cdot, \leqslant \leqslant r$ & I, TV & ترك مساففات مناسبة بين النباتات حو الى 0 اسم & \\
\hline منخفض & $0 \%, 10$ & $\cdot$, , YTV & $1, \cdot 1$ & |لعزيق & \\
\hline 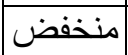 & $7, Y \Lambda$ & $\cdot, \leqslant 19$ & $1, \Gamma^{\mu}$ & ازاز الة الحشائش من على الطرق و المساقى و الترع & $\Lambda$ \\
\hline 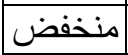 & $7 \pi, 1 \mathrm{~V}$ & $\cdot, \varepsilon \mid \mathrm{V}$ & $1, Y 7$ & إجمالى الإحتياج التنفيذى للعمليات الزر اعية & \\
\hline & & & & ل بالنسبة للمكافحة الحيوية & \\
\hline مرتفع (مرتح & $9 \mathrm{~T}, 10$ & $\cdot$ & 1,11 & إستخدام البكتيريا الممرضة & 9 \\
\hline 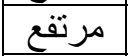 & 90,9 . & $\cdot$, TVO & 1,94 & | إستخدام النيماتودا الممرضة & 1. \\
\hline 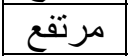 & $91, \leqslant 7$ & $\cdot, \mathrm{IVT}$ & $1,9 \mathrm{~V}$ & | إستخذام الفطريات الممرضة & 11 \\
\hline 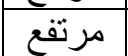 & $9 \cdot, 17$ & $\cdot, \mathrm{rqv}$ & $\mid, \wedge !$ & إستخذام المفترسات مثل ابو العيد & Ir \\
\hline 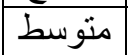 & $V T, \cdot A$ &., $0 \ldots$ & $1, \leqslant 7$ & إستخدام طفيل الترايكوجر اما بمعدل Vo حشره فى المتر المربع & 14 \\
\hline مرتفع & 90,14 & $\cdot, Y 9 \mathrm{Y}$ & 1,99 & إبتخدام منظمات النمو لهنع نمو الحشره & $1 \varepsilon$ \\
\hline 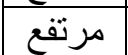 & $9 \vee, \leqslant \varepsilon$ & $\cdot, Y Y T$ & 1,90 & إستخدام فرمونات التشويش & 10 \\
\hline متوسط & VY,OT & $\cdot, \leqslant 99$ & $1, \leqslant 0$ & إستخدام الفرمونات الجنسية عن طريق المصائد الفرمونبة المائية & 17 \\
\hline 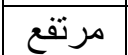 & 19,01 & דוז"ז & 1,199 & إجمالى الإحتباج التنفيذى للمكافحة الحيوية & \\
\hline & & & & ل ب النسبة لبائل المبيدات & \\
\hline متوسط & $79, \leqslant 9$ & $\cdot, \varepsilon \wedge 9$ & 1,49 & إستخذدام كبريتات الالومونيو و والبوتاسيوم المائية (الثبة الزفره) & IV \\
\hline متوسط & $77, ६ 1$ & $\cdot, \varepsilon \vee 1$ & $1, \pi$ & إبتخدام الكبريت الزر اعى & 11 \\
\hline منوسط & $7 V, 90$ & $\cdot,\{\wedge 1$ & $1, \pi 4$ & | إستخدام السو لار & 19 \\
\hline 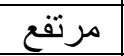 & $A r, \cdot 0$ & $\cdot, \varepsilon \wedge 1$ & $1,7 \varepsilon$ & إستخذام خميره البيره كمادة مطهره تقضى على الفطريات & r. \\
\hline متوسط & 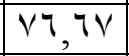 & $\cdot, 0 \ldots$ & 1,04 & |إستخدام العسل الاسود & r) \\
\hline 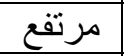 & 10,14 & $\cdot, \leqslant 01$ & $1, \mathrm{v} \cdot$ & إبتخذام منقو ع سماد السوبر فوسفات وسلفات البوتاسيوم & rt \\
\hline 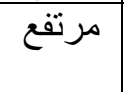 & 14,10 & $\cdot, \leqslant \leqslant 9$ & $1, \mathrm{VY}$ & الطياره إنخ زيت الرجوع فى عمل المصائد الثحمية لإصطياد الحشرات & rT \\
\hline متوسط & $V 7,9 Y$ & $\cdot, 0 \ldots$ & $1,0 \varepsilon$ & إستخذام الصـابون المتعادل & \\
\hline منوسط & $V 7, r_{0}$ & $\cdot, \sum \vee 9$ & 1,04 & إجمالى الإحتياج التنفيذى لبدائل المبيدات & \\
\hline | متوسط & $V 4, r V$ & $\cdot . \leqslant 11$ & 1,05 & المستوى العام & \\
\hline
\end{tabular}

Fayoum J. Agric. Res. \& Dev., Vol. 34, No.2 July, 2020 
or

جدول (V): قيم معامل الارتباط البسيط لبيرسون وقيم مربع كاى بين الإحتياج المعرفى لممارسات ترشيد

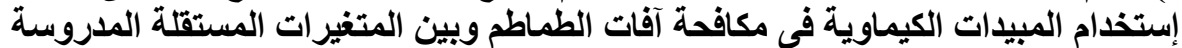

\begin{tabular}{|c|c|c|c|c|c|c|c|}
\hline \multirow{2}{*}{ قالمعدله (كال) } & \multirow{2}{*}{ قالارتباط معامل } & \multicolumn{4}{|c|}{ مستوى الإحتياج المعرفى } & \multirow[b]{2}{*}{ الفئات } & \multirow[b]{2}{*}{ المتغيرات } \\
\hline & & 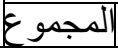 & 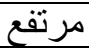 & منوسط & منخفض & & \\
\hline & \multirow{3}{*}{$* * \cdot, \leqslant Y !-$} & $r 9$ & $\cdot$ & $1 \Gamma$ & 17 & 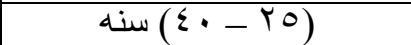 & \multirow{3}{*}{ السن } \\
\hline & & 90 & iT & Vo & V & (OV - El) & \\
\hline & & VI & 1 & $0 \leqslant$ & 17 & سنه (VT-ON) & \\
\hline \multirow{4}{*}{$* * \wedge \uparrow, \wedge 0$} & & $\sum 7$ & $1 \varepsilon$ & Tr & - & أمى & \multirow{4}{*}{ المستوى التعليمى } \\
\hline & & 77 & - & 01 & $\Lambda$ & يقزا ويكتب & \\
\hline & & vo & . & 01 & TE & حاصل على مؤهل منوسط & \\
\hline & & $\Lambda$ & . & 1 & $\mathrm{~V}$ & حاصل على مؤهل جامعي & \\
\hline \multirow[t]{3}{*}{ **T1,71 } & & $\pi$ & 1 & $9 \leqslant$ & ro & يقوم بزر اعة ارضها بنفسهة & \multirow{2}{*}{ ممارسة العمل } \\
\hline & & 70 & $\pi$ & $\sum \lambda$ & $\varepsilon$ & يوكل اخرين في زر اعة ارضها & \\
\hline & \multirow{3}{*}{$* *, \Gamma 70$} & 91 & $1 \leqslant$ & $V 7$ & $\Lambda$ & حيازه صغيره (اقل من ا ) فدان & \multirow{3}{*}{ حجم الحيازه الزراعية } \\
\hline & & $7 \pi$ & - & $\leqslant \varepsilon$ & 19 & حيازه متوسطة (من I - ؟ ؟) فدان & \\
\hline & & Tร & $\cdot$ & TY & IT & حبازه كبيره (اكثر من r) فدان & \\
\hline & \multirow{3}{*}{$* * \cdot, \leqslant \vee \wedge$} & $\Lambda \wedge$ & . & ov & T1 & مساحة صغيره (اقل من () فدان & \multirow{3}{*}{ المساحة المنزرعة } \\
\hline & & VV & T & $7 V$ & $\Lambda$ & مساحة متوسطة (من ا - T) فدان & \\
\hline & & $\Gamma \cdot$ & Tr & 11 & $\cdot$ & مساحة كبيره (اكثر من بَ) فدان & \\
\hline & \multirow{3}{*}{$* *, 01 \cdot-$} & VI & IE & OV & $\cdot$ & خبره قلبلة (r - • (1) سنه & \multirow{3}{*}{ زدراعة الطماطبر في في } \\
\hline & & 77 & - & or & Tร & خبره منوسطة (1 19 - 9 (1) سنها & \\
\hline & & 01 & - & "ז & ro & خبره كبيره (اكثر من · Y) سنه & \\
\hline & \multirow{4}{*}{$* *, 190$} & $\overline{V T}$ & T & $\leqslant 9$ & TY & لا يوجد & \multirow{4}{*}{ 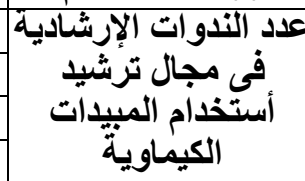 } \\
\hline & & $\varepsilon \wedge$ & $\Lambda$ & $r \cdot$ & $1 \cdot$ & ) ندوه & \\
\hline & & 01 & $\varepsilon$ & $\sum Y$ & 0 & 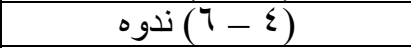 & \\
\hline & & TT & - & YI & T & ندوه $(9-V)$ & \\
\hline \multirow{3}{*}{$\Lambda, Y, T$} & & 79 & 7 & $\xi \cdot$ & TM & منخفضة (7 - 9) درجه & \multirow{3}{*}{ درجة الإستعداد للتغيير } \\
\hline & & 91 & 7 & $\mathrm{VA}$ & $\mathrm{V}$ & متوسطة (· ( - ع أ) درجة & \\
\hline & & ro & r & TE & 9 & مرتفعة (10 - 1 1 ) درجة & \\
\hline \multirow{3}{*}{$r, 1 Y * *$} & & $\Lambda \Lambda$ & $T$ & 74 & TE & غير راضىى & \multirow{3}{*}{ دزرجة الرضة الطماطن انتاج } \\
\hline & & VI & 0 & $0 \leqslant$ & Tr & ر راضى لحد ما & \\
\hline & & r7 & $\Lambda$ & TO & $r$ & راضى تماما & \\
\hline \multirow{3}{*}{$9, Y_{1}$} & & $\mathrm{VA}$ & 7 & VI & T & أقل من متوسط انتاج القرية & \multirow{3}{*}{ مستوى الإنتاجية من } \\
\hline & & VV & 0 & or & r. & حول المتوسط & \\
\hline & & rq & $T$ & 19 & TV & اعلى من المتوسط & \\
\hline
\end{tabular}

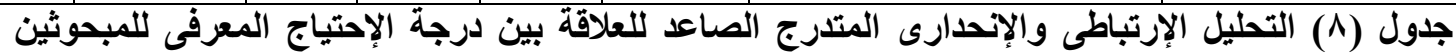

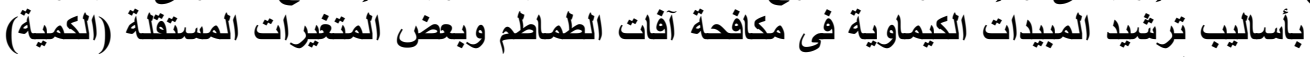
المدروسية

\begin{tabular}{|c|c|c|c|c|c|c|}
\hline "تيمة & معامل الآندئي & 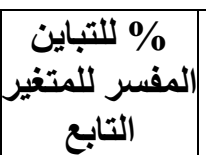 & للتباين المفسر التبر & الارتباط & المتفير الداخل فى التحليل & خطوات التحيل \\
\hline$* * r, \xi$ & (1) &., 019 & $\cdot, 019$ & $\cdot, \mathrm{VY}$. & المساحة المنزر عة طماطم & الاولى \\
\hline$* Y_{,}, Y_{-}$ & $\cdot, \cdot V V-$ & $\cdot, \cdot \wedge 7$ &., 7.0 & $\cdot, \vee \vee \wedge$ & عدد سنو ات الخبره فى زر اعة الطماط户 & الثانية \\
\hline$* * r, 0 \leq \ldots$ & $\cdot, 10-$ & $\cdot, 11$ & • & $\cdot, \vee \wedge 9$ & السن & الثالثة \\
\hline$* Y, \leqslant V$ & $\cdot, r \backslash \wedge$ & $\cdot, \cdot 1 Y$ & . & $\cdot, \vee 9 \vee$ & حجم الحيازه الزراعية & الرابعة \\
\hline
\end{tabular}

Fayoum J. Agric. Res. \& Dev., Vol. 34, No.2 July, 2020 
๑ะ

جدول (9) التحليل الإرتباطى والإنحارى المتدرج الصاعد للعلاقة بين درجة الإحتياج المعرفى للمبحوثين بأساليب

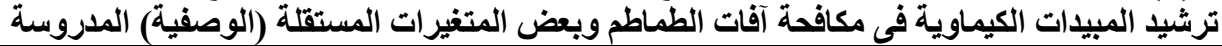

\begin{tabular}{|c|c|c|c|c|c|c|}
\hline "قيمة" & معامل الانحدار & | المفسر للمتغنير & للتباين المفسر التير & الارتباط معامل & المتغير الاخل فى التحليل & خطوات \\
\hline$* * r, r V_{-}$ & r, TTV_ & .,017 &., 0 ry & $\cdot, \mathrm{VTr}$ & المستوى التعليمىى & الاولى \\
\hline$* * \Gamma, 1 \leq$ & $\cdot, \vee 71$ & $\cdot, 19$ & $\cdot, 000$ & $\cdot, \mathrm{V} \leqslant 0$ & درجة الرضا عن انتاج وزر اعة الطماطم & الثانية \\
\hline$* r_{1}, u_{-}$ & $1, \cdot \lambda r$ & $\cdot, \cdot 1 r$ &., $07 \mathrm{~V}$ & $\cdot, \mathrm{VOr}$ & ممارسة العمل المزر عى & الثالثة \\
\hline
\end{tabular}

جدول (• (): قيم معامل الارتباط البسيط لبيرسون وقيم مربع كاى بين الإحتياج التنفيذى بترشيد إستخدام

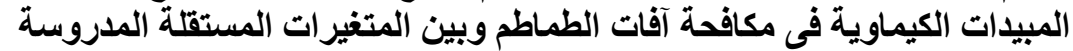

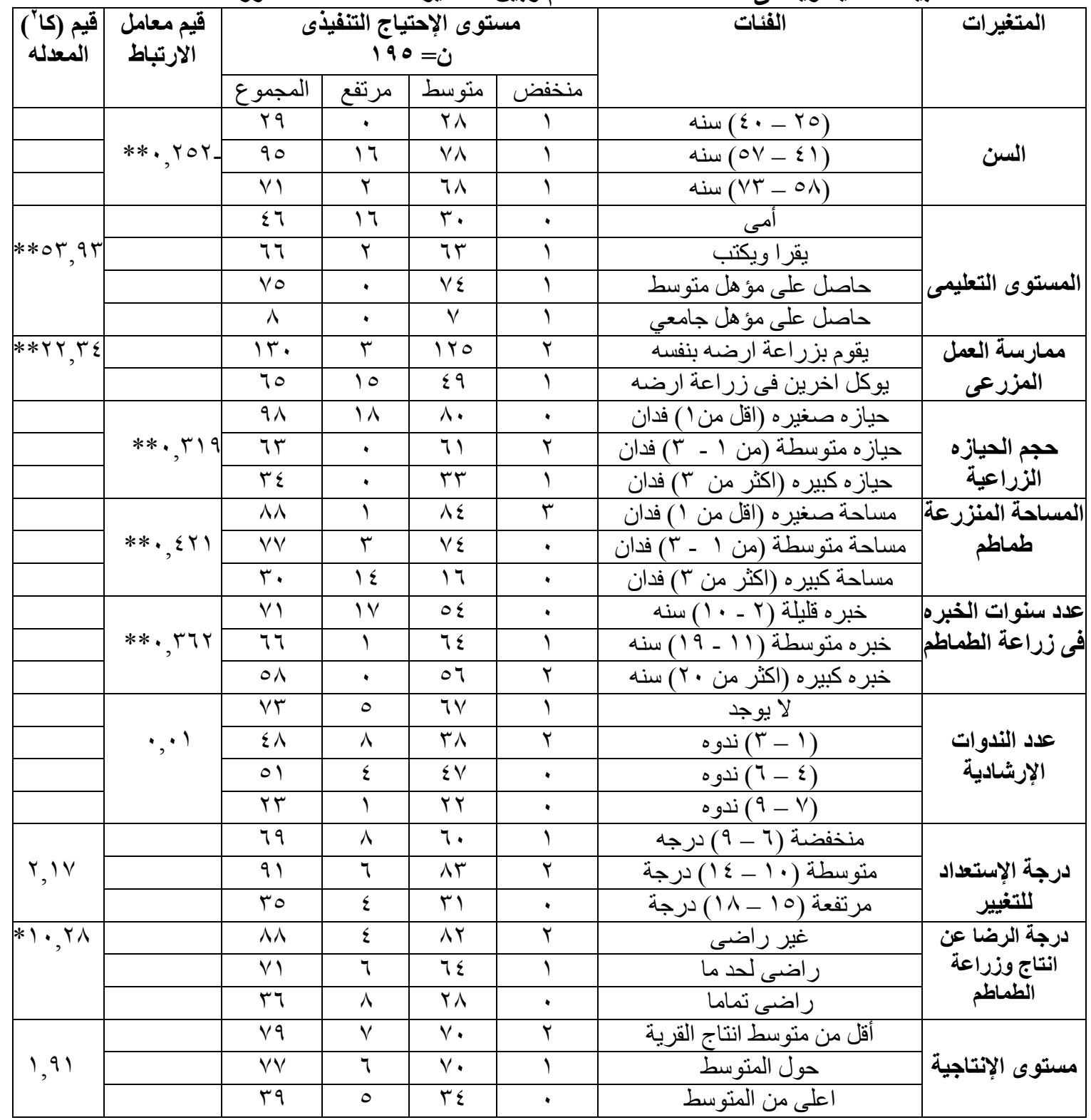

Fayoum J. Agric. Res. \& Dev., Vol. 34, No.2 July, 2020 
$\bullet \bullet$

جدول (11) التحليل الإرتباطى والإنحارى المتدرج الصاعد للعلاقة بين درجة الإحتياج التتفيذى للمبحوثين بأساليب

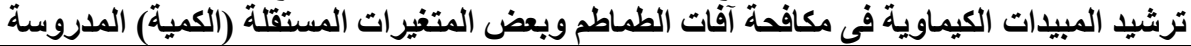

\begin{tabular}{|c|c|c|c|c|c|c|}
\hline "تيمة" & معامل الانحدار & 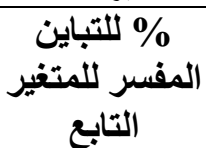 & |للتباين المفسر التبرية & 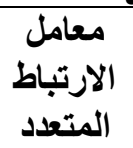 & المتغير الداخل فى التحليل & خطوات التحليل \\
\hline$* * \Gamma, T)$ & $.09 r$ & $\cdot, \Gamma \wedge \wedge$ & $\cdot r \wedge \wedge$ & תזT, & المساحة المنزر عة طماطم & الاولى \\
\hline$* * \mu, \mu_{0}$ & $\cdot r \leqslant 0$ & $\cdot \cdot \Gamma \varepsilon$ & $\cdot \varepsilon Y Y Y$ & .70 & حجم الحبازه الزراعبة & الثانية \\
\hline
\end{tabular}
جدول ( r I ) التحليل الإرتباطى والإنحدارى المتدرج الصاعد للعلاقة بين درجة الإحتياج التنفيذى للمبحوثين

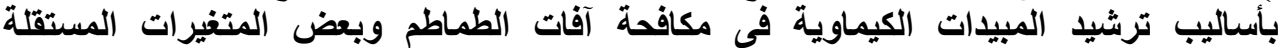

$$
\text { (الوصفية) المدروسية تربيد }
$$

\begin{tabular}{|c|c|c|c|c|c|c|}
\hline "قيمة & معامل الانحدار & 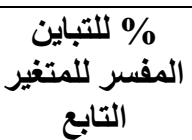 & للتباين المفسر التزية & الارتباط & المتغير الداخل فى التحليل & التحليل \\
\hline$* * r, Y V_{-}$ & r,77V- &., 047 & .,047 & $\cdot, \mathrm{VTY}$ & المستوى التعليمى & الاولى \\
\hline$* * r, 1 \leq$ & $\cdot, \times 71$ & $\cdot, \cdot 19$ & $\cdot, 000$ & $\cdot, \mathrm{V} \leqslant 0$ & درجة الرضا عن انتاج وزر اعة & الثانية \\
\hline
\end{tabular}

جدول (rآ (1): توزيع المبحوثين وفقاً للخدمات الإرشادية المقدمة من الإرشاد الزراعى من وجهة نظرهم لترشيد إستخدام المبيدات الكيماوية في مكافحة آفات الطية الطماطم

\begin{tabular}{|c|c|c|c|c|c|c|c|c|c|}
\hline$\%$ & $\gamma$ & $\%$ & نادرا & $\%$ & احياناً & $\%$ & دائماً & الخدمات الإرشـادية & م \\
\hline Or,A & $1 \cdot r$ & $T V, V$ & $0 \leqslant$ & $T, r$ & $r \varepsilon$ & $V, Y$ & $1 \varepsilon$ & 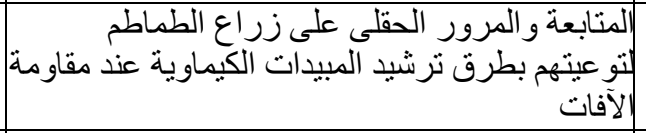 & $T$ \\
\hline 97,9 & 119 & $r, 1$ & 7 & - & - & - & - & 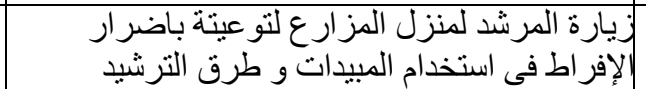 & r \\
\hline$\varepsilon r, T$ & $\Delta \Gamma$ & $r q, Y$ & OV & 10,9 & $T$ & $\mid Y, Y$ & $T \varepsilon$ & 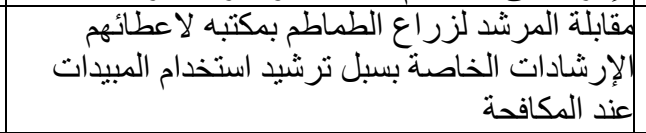 & $\Gamma$ \\
\hline $11, r$ & YY & $1 \leqslant, 9$ & rq & $\varepsilon V, V$ & 94 & $\mid r q, 1$ & 01 & 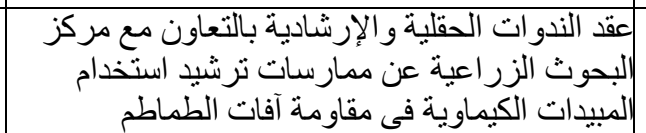 & $\varepsilon$ \\
\hline 71 & 119 & $r r, T$ & $\leqslant 7$ & $7, Y$ & $T$ & $9, Y$ & 11 & 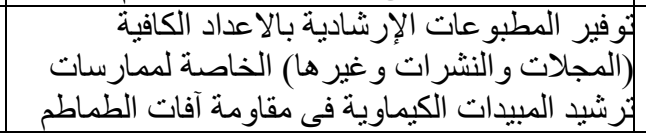 & 0 \\
\hline$\Lambda \Lambda, Y$ & IVT & $v, r$ & $1 \varepsilon$ & $\varepsilon, 7$ & 9 & - & - & 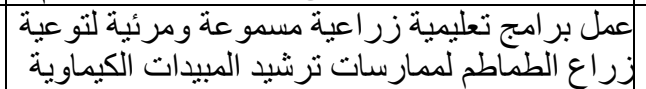 & 7 \\
\hline $1 \cdots$ & 190 & - & - & - & - & - & - & 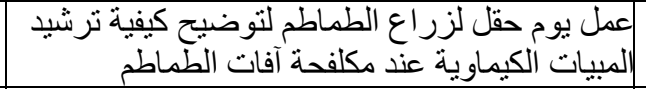 & $\mathrm{v}$ \\
\hline $0 \mathrm{or}, 1$ & 1.0 & $9, Y$ & 11 & $1 \leqslant, \varepsilon$ & YA & $r \quad, T$ & $\varepsilon \varepsilon$ & 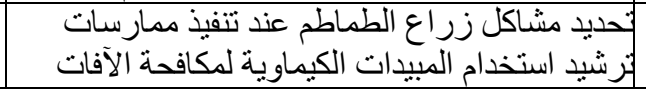 & $\Lambda$ \\
\hline ov, 9 & $11 \pi$ & 11,0 & ry & $I r, \Lambda$ & ro & $1 \cdot, \lambda$ & YI & 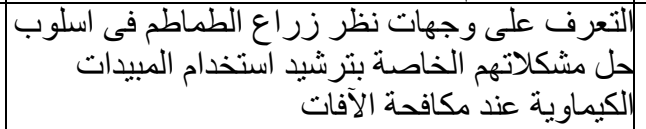 & 9 \\
\hline 09,0 & 117 & ro, 7 & 0. & $\Lambda, r$ & 17 & $7, \mathrm{~V}$ & 15 & 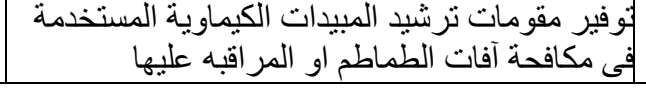 & \\
\hline
\end{tabular}

Fayoum J. Agric. Res. \& Dev., Vol. 34, No.2 July, 2020 
07

جدول (ع ا): المشاكل التى تواجه المبحوثين عند ترشيد استخدام المبيدات الكيماوية في مكافحة آفات الطماطم

\begin{tabular}{|c|c|c|c|}
\hline الترتيب & $\%$ & تكرار & المشـاكل التي تواجه الزراع \\
\hline r & $94, r$ & $1 \wedge$. & ا ـ ضعف الإنتاج فى حالة ترشيد استخدام المبيدات الكيماوية \\
\hline 7 & 11,0 & 109 & r ـ صعو بة تغيير بعض الممارسات و السلوكيات الخاطئة لدى زر اع الطماطم \\
\hline$\Lambda$ & Vo, 9 & $1 \leqslant \Lambda$ & "ـ عدم توفر بدائل للمبيدات مع ارتفاع اسعار ها ان وجدت \\
\hline 0 & 10,7 & $17 \mathrm{~V}$ & ع ـ قلة اوندرة مقومات المكافحة الحيوية \\
\hline r & $90, \xi$ & $1 \wedge 7$ & 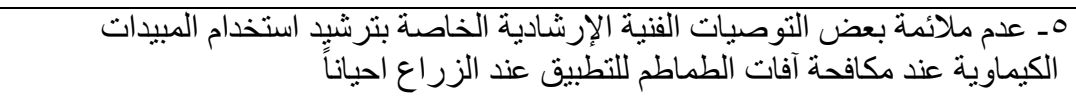 \\
\hline$\varepsilon$ & $\wedge 9, Y$ & $1 V \varepsilon$ & 7ـ نقص الرقابة على نو عية المبيدات المستخدمة لمقاومة آفات الطماطح \\
\hline 9 & $0 \leqslant, \varepsilon$ & 1.7 & 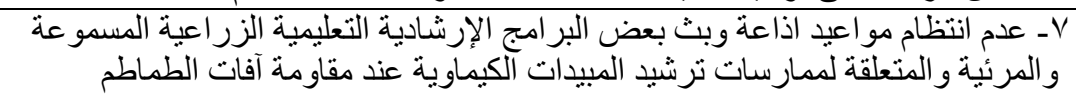 \\
\hline $\mathrm{V}$ & $V \vee, 9$ & 104 & مـ عدم مر اعاة المرشد الزر اعى الفروق بين الزراع المتعلمين و الاميين \\
\hline 1 . & $\varepsilon 7, V$ & 91 & 9ـ انعدام التقة بين الزراع و المرشدين الزر اعيين . \\
\hline 1 & 97,9 & 119 & 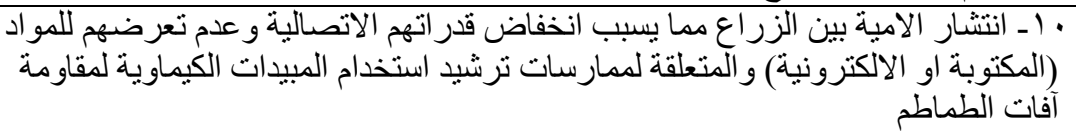 \\
\hline
\end{tabular}

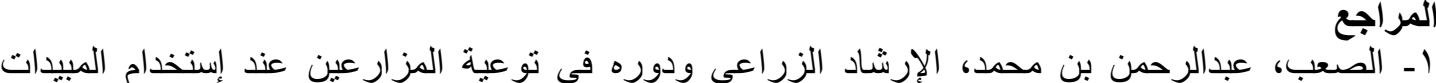

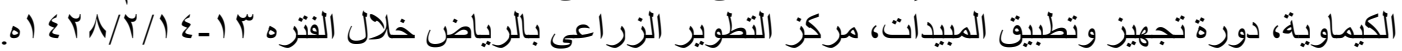

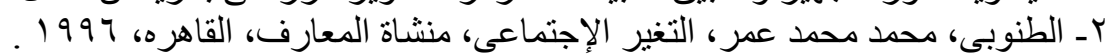

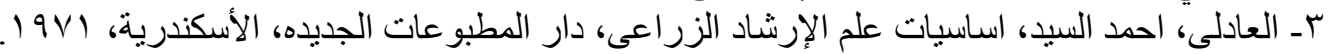

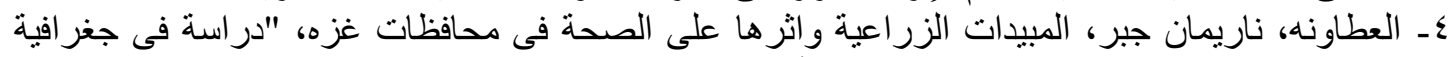

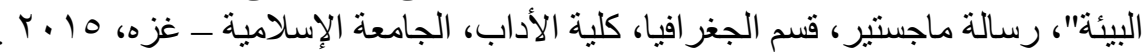

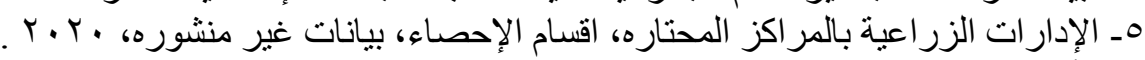

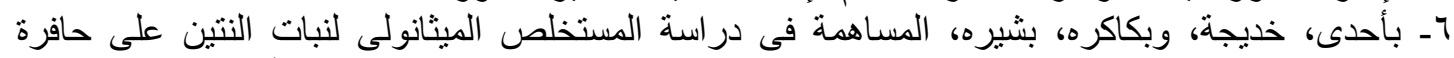

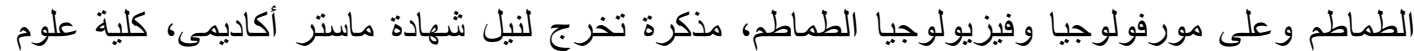

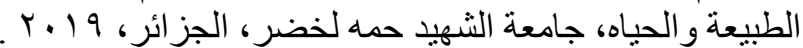

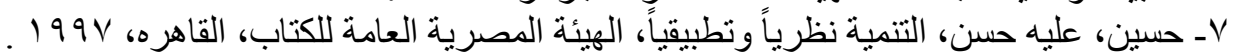

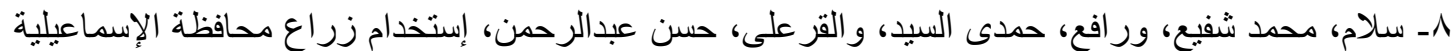

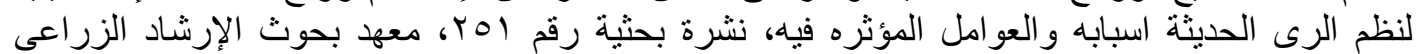

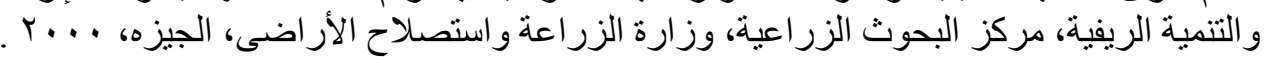

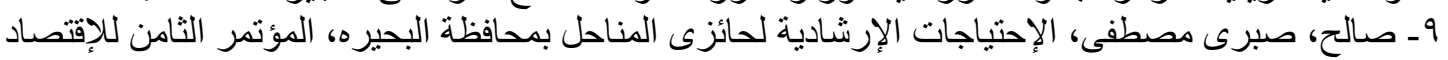

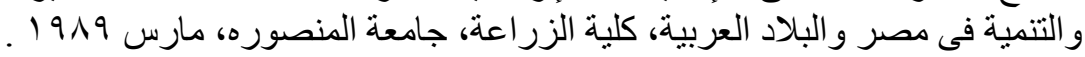

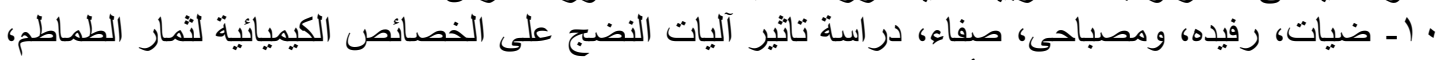

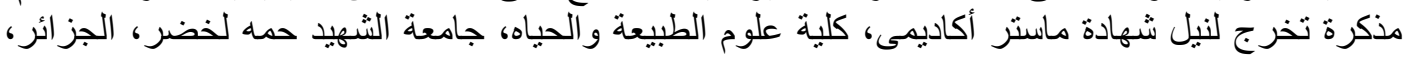
$r \cdot 19$

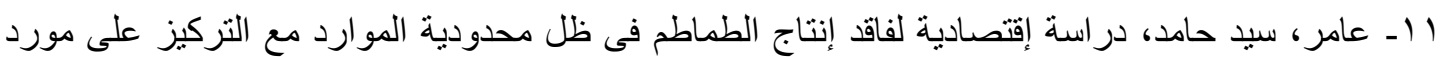

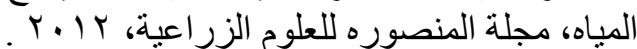

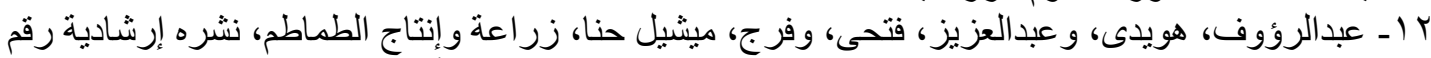

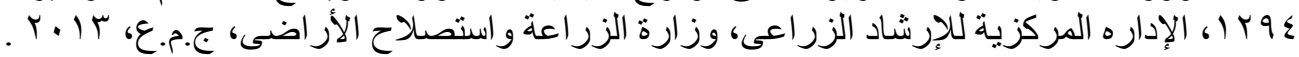

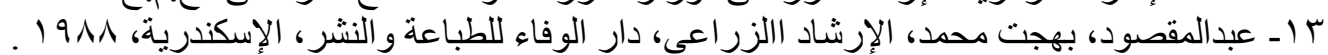

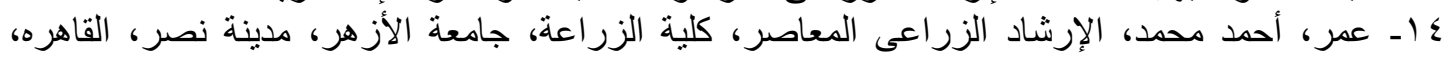

10 ـ عمر ، أحمد محمد، وابو السعود، خيري، وابوشعيشع، طه، و الر افعى، احمد، المرجع فى الإرشاد الزراعى،

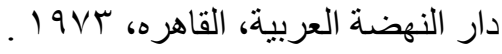

Fayoum J. Agric. Res. \& Dev., Vol. 34, No.2 July, 2020 
$\bullet V$

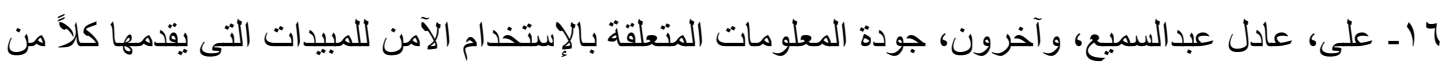

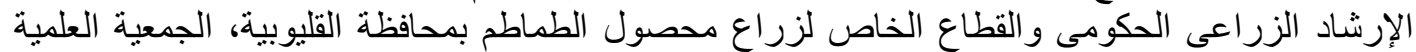

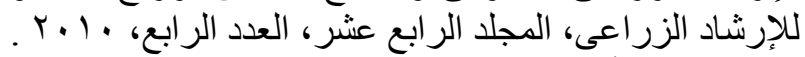

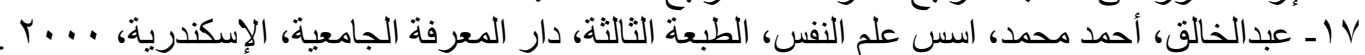

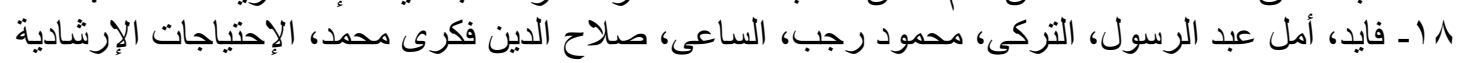

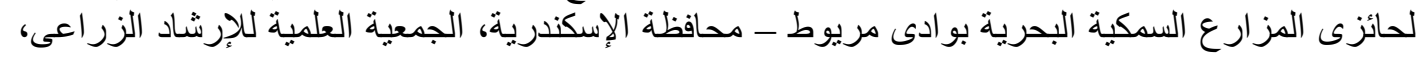

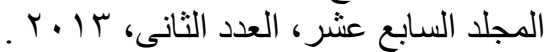

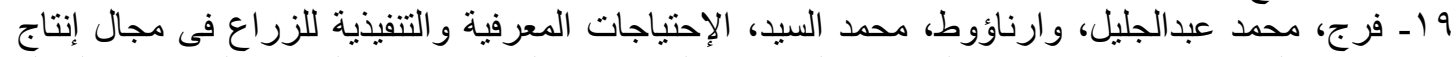

$$
\begin{aligned}
& \text { وتسويث البطاطس فى محافظات البحيره والمنوفية و الغربية، مجلة الإنتاجية و التنمية، الزقازيق، المجلد }
\end{aligned}
$$

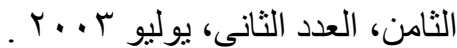

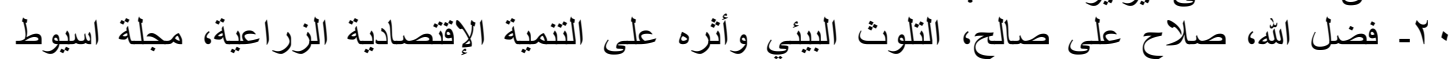

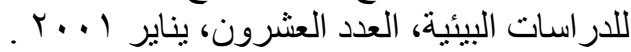

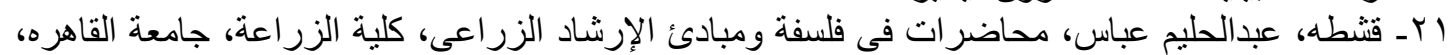

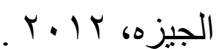

$$
\begin{aligned}
& \text { Y بـ قنديل، نبيل، التلوث البه البيئي بالمبيدات الكيماوية الزراعية، معهد بحوث الأراضي والمباه والبيئة، مركز }
\end{aligned}
$$

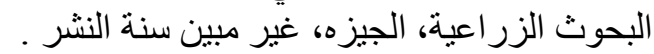

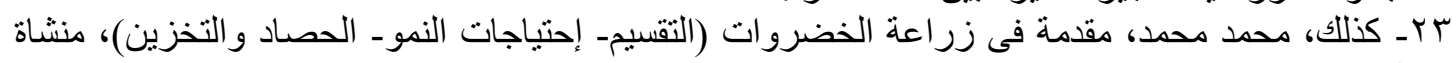

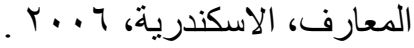

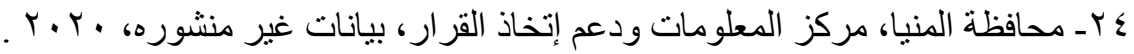

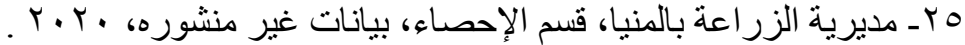

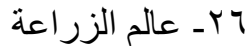

http://www.agricultureegypt.com/NewsDetails.aspx?CatID=0602908b-146a-

4435-a9fd-1ccb063c300e . visited in 21/3/2020.

27- Fred.p.frutchy, The learning teaching process, hal-inc.c.N.J.U.S.A, 1966 .

28- Krejicie, R.V. and Morgan, W. "Education and Psychological Measurement

College Station" Durham North Corolina, 1970.

29- Rabb, R.T, B,E.Swanson T.L wanting, and C.D clack, A trainers guide to evaluation, FAO, Rome 1987.

\section{EXTENSION NEEDS OF FARMERS FOR RATIONALIZATION OF THE USE OF CHEMICAL PESTICIDES IN THE CONTROL OF TOMATO PESTS IN SOME VILLAGES OF MINIA GOVERNORATE}

*Dr/ Adham Mohamed Zaky Mahmoud ** Dr/ Abd el-naser Mohamed Fath el-bab

*Extension and Training Department - Central Laboratory for Organic Agriculture-ARC

** Higher institute for cooperation and agricultural extension - Assiut

\section{ABSTRACT}

The research aimed to determining the level of knowledge and implemention needs of respondents farmers to the practices of rationalizing use of chemical pesticides in the control of tomato pests, in addition to determine the correlation and regression relationship between independent variables of respondents and the degree of knowledge and implemention need to practices of rationalizing the use of chemical pesticides for it, also identifying extension services Provided by the agricultural extension to rationalize the use of chemical pesticides in control of tomato pests, finally identifying the problems facing the respondents farmers when rationalizing the use of chemical pesticides in control of tomato pests from their point of view.

This research was conducted in Minia Governorate, where the three largest district of area cultivated with tomatoes, they were: Samalout, Minia, Dermawas, it was followed with the same way, it was selected the largest village of each districts, they were: Village 4 in

Fayoum J. Agric. Res. \& Dev., Vol. 34, No.2 July, 2020 
Samalout district, Bani Ahmed in Minia district, Dalga in Dermawas district, and to achieve objectives of the research it were selected systematic random sample amounted to 195 respondents in three selected villages.

The study data were collected by using the questionnaire with the personal interview during the March and April 2020, it was used frequency and percentages, arithmetic mean, the standard deviation,simple correlation coefficient of Pearson, chi square, and multiple regression analysis step-wise used to analyze the studied data .

\section{The main research results are summarized as follows:}

- The majority of respondents farmers $(80 \%)$ were located in medium and high knowledge need categories of practices of rationalizing the use of chemical pesticides in contro of tomato pests.

- The majority of respondents farmers $(89.2 \%)$ came in the category of medium implemention need for rationalization practices of the use of chemical pesticides in the control of tomato pests.

- There is a significant relationship at the level of 0.01 between: age, educational level, practice of farm work, size of agricultural tenure, cultivated area of tomato, number of years of experience in tomato cultivation, number of guiding seminars, degree of satisfaction with tomato cultivation and knowledge need degree to practices of rationalization of the use of chemical pesticides in control of tomato pests,. the results also indicate that the independent (quantitative) variables combined explain $63.5 \%$ of the variance in the cognitive need, while the independent (descriptive) variables together explain 56.7\%.

- It was found that there was a significant correlation at 0.01 level between: age, educational level, practice of farm work, size of agricultural tenure, cultivated area, tomato, number of years of experience in planting tomatoes, while it was significant at the level of 0.05 with degree of satisfaction with cultivation tomatoes and implemention need degree to the practices of rationalizing the use of chemical pesticides in control of tomato pests, the results also indicate that the independent (quantitative) variables combined explain $42.2 \%$ of the variation in the implemention need, while the independent (descriptive) variables combined explain $55.5 \%$.

- It was also evident that the extension services provided by the extension agency were weak to rationalize the use of chemical pesticides in combating tomato pests.

- The most important problems that farmers face when rationalizing the use of chemical pesticides in control of tomato pests from their point of view ranged from a higher limit of (96.9\%) related to the spread of illiteracy among farmers, which causes a decrease in their communication capabilities and not being exposed to materials (written or electronic) related to rationalization practices The use of chemical pesticides in the control of tomato pests, and a minimum of (46.7\%), which relates to the lack of confidence between farmers and extension workers . 